Universidade de São Paulo

Faculdade de Filosofia, Letras e Ciências Humanas

Departamento de História

Programa de pós-graduação em História Social

ANA CLAUDIA FERNANDES

\title{
REVOLUÇÃO EM PAUTA: O DEBATE CORREO DEL ORINOCO - CORREIO BRAZILIENSE (1817-1820)
}


ANA CLAUDIA FERNANDES

\section{REVOLUÇÃO EM PAUTA: O DEBATE \\ CORREO DEL ORINOCO - CORREIO BRAZILIENSE (1817-1820)}

Dissertação de Mestrado apresentada ao Programa de Pós-Graduação em História Social, do Departamento de

História da Faculdade de Filosofia, Letras e Ciências Humanas da Universidade de São Paulo, sob orientação do Prof. Dr. João Paulo Garrido Pimenta.

(Texto em conformidade com o Acordo Ortográfico de 2009)

São Paulo

2010 
Para Manoela, responsável pela grande revolução da minha vida. 


\section{AGRADECIMENTOS}

A elaboração deste trabalho contou com o apoio de várias pessoas às quais quero manifestar os meus sinceros agradecimentos: ao professor Frederico Tomé, que me forneceu o arquivo de seu trabalho; à professora Inês Quinteiro, da Universidad Central de Venezuela, pela recepção cordial e por indicar-me os caminhos da pesquisa na cidade de Caracas; ao professor Valdei Araújo, da Universidade Federal de Ouro Preto e ao grupo amigo de orientandos do professor João Paulo (Adriana Leme, André Fróes, Cristiane Camacho, Jaqueline Lourenço e Júlia Neves), cujas críticas e comentários foram muito importantes; ao professor István Jancsó e à professora Wilma Peres Costa, pelas valiosas indicações feitas durante o exame de qualificação deste trabalho; aos amigos Gilmar Panza, Marisa Martins Sanchez e Cristiane Alves Camacho que muito contribuíram com interlocuções, leituras e indicações; à Tathiane Gerbovic, amiga que revisou atentamente vários trechos deste trabalho e por muitas vezes me auxiliou retirando e entregando material na biblioteca da faculdade; ao Carlos Luvisari e ao Fernando Eraso, pelo esforço conjunto para conseguir-me um exemplar da edição fac-similar do Correo del Orinoco - material fundamental para a execução deste trabalho; e à Cleide Rosa de Jesus, pela ajuda na importação de uma importante referência bibliográfica.

Devo muito mais que agradecimentos ao Franscisco Fernandes de Souza e à Maria Goretti Fernandes, pais amorosos que representaram o exemplo de coragem e persistência; à amiga Andréa Slemian, pela generosidade com a qual me abrigou nos primeiros anos da graduação, e pelas orientações de sempre; ao amado esposo André Luís de Almeida pelo incentivo, apoio emocional e por ter sido um superpai principalmente nos momentos em que não consegui ser mãe em razão das atribulações dos trabalhos.

Por fim, um agradecimento especial ao professor João Paulo Garrido Pimenta pela orientação, sem a qual não teria sido possível realizar esta dissertação. 


\section{RESUMO}

Este é um estudo sobre o debate entre dois periódicos publicados em meio aos processos de independências políticas da América ibérica: o Correio Braziliense e o Correo del Orinoco. Ocorrido entre os anos de 1817 e 1820, o diálogo motivado pelos acontecimentos de Pernambuco em 1817, converteu-se em um debate sobre revolução, conceito-chave para o entendimento daquela conjuntura, tendo como perspectiva a interação e influência mútua entre duas de suas vertentes: Brasil e Venezuela.

\section{ABSTRACT}

This is a study about the debate between two periodicals published during the Iberian America political independence process: Correio Braziliense and Correo del Orinoco. Occurred between 1817 and 1820, the dialog motivated by the events from Pernambuco in 1817 , became a debate about revolution, key concept to understanding that conjuncture, through the perspective of the interaction and mutual influence between two of its exponents: Brazil and Venezuela.

\section{PALAVRAS-CHAVE}

revolução, vocabulário político, imprensa, independência, Venezuela, Pernambuco.

\section{KEYWORDS}

revolution, political vocabulary, press, independence, Venezuela, Pernambuco. 
SUMÁRIO

- INTRODUÇÃO

007

- CAPÍTULO 1: A IMPRENSA NA AMÉRICA IBÉRICA

015

1.1- A imprensa na Venezuela e o Correo del Orinoco

016

1.2- A imprensa no Brasil e o Correio Braziliense

028

- CAPÍTULO 2: A CRISE POLÍTICA DOS IMPÉRIOS IBÉRICOS

039

2.1- Investidas napoleônicas: os primeiros impactos na

América ibérica (1808-1809)

2.2- A contestação ao poder metropolitano pela América espanhola e sua repercussão no Brasil (1810-1813)

2.3- O fim do domínio napoleônico: Brasil e Venezuela na tentativa de reordenação do mundo ibérico (1814-1816)

- CAPÍTULO 3: 1817

3.1- Novos esforços para o estabelecimento da

República na Venezuela

3.2- A contestação da ordem metropolitana em Pernambuco, 1817:

um ensaio republicano no Brasil

- CAPÍTULO 4: REVOLUÇÃO EM PAUTA

4.1- Significados de Revolução

4.2- Os termos do debate: Correo del Orinoco - Correio Braziliense

- FONTES E BIBLIOGRAFIA 


\section{INTRODUÇÃO}

Objetivamos estudar o debate entre dois periódicos publicados em meio aos processos de independências políticas da América ibérica: o Correio Braziliense e o Correo del Orinoco. Travado entre 1817 e 1820, tal debate teve como eixo central os acontecimentos de Pernambuco em 1817, e nos conduz à ideia de revolução como conceito-chave para o entendimento daquela conjuntura, tendo como perspectiva a influência e interação mútua entre duas de suas vertentes: Brasil e Venezuela. ${ }^{1}$

Como todo diálogo, realizou-se num espaço de ação compartilhado, onde as partes interagiram conceitualmente. Portanto, para sua análise, é imperativo o entendimento dos significados de revolução e termos correlatos para caracterização dos discursos - singularmente e no que se articulam -, a fim de mensurar até que ponto as diferentes posições dos periódicos refletiam diferenças de posicionamentos e projetos políticos existentes nas Américas portuguesa e espanhola, e como estes interagiam numa conjuntura mais ampla. Assim, o breve estudo semântico do termo chave do debate é ferramenta necessária para análise do quadro político em questão, e da forma como este era entendido pelos periódicos contendores, e não objetivo do trabalho. $^{2}$

A interlocução entre o Correio Braziliense e o Correo del Orinoco se insere num contexto resultante de um processo iniciado no século XVIII, quando mutações múltiplas no campo das ideias e dos comportamentos, concomitantes às alterações

\footnotetext{
${ }^{1}$ TOMÉ, Frederico Castilho - A Causa Americana na Perspectiva do Correio Braziliense e do Correo del Orinoco. Universidade de Brasília, Dissertação de mestrado, 2005 -, analisou o mesmo debate entre os dois periódicos e estudou comparativamente suas propostas políticas tendo como perspectiva a "maturação do ideal de independência nos antigos territórios americanos pertencentes a Portugal e Espanha”. Contudo, como se verá, o nosso tratamento ao tema difere, substancialmente, do trabalho de Castilho Tomé.

${ }^{2}$ Para distinção entre história política e estudo da linguagem conceitual: KOSELLECK, Reinhart. A semântica histórico-política dos conceitos antitéticos assimétricos. In.: Futuro Passado. Contribuição à semântica dos tempos históricos. Rio de Janeiro: Contraponto, Editora PUC-Rio, 2006, p. 191-233.
} 
político-econômicas e sociais do quadro europeu, em interação com os valores do Antigo Regime, propiciaram a emergência de um novo sistema de referências, convencionado como modernidade. Resumidamente, poder-se-ia caracterizar tal ocorrência como uma alteração gradativa de valores, iniciada com os ideais iluministas, segundo os quais a razão é o principal critério norteador para comportamentos, instituições e também para o Estado. Dessa maneira, o indivíduo, como portador da razão, passou a ser referência deste processo de mutação de ideias, conceitos e práticas. $^{3}$

A estas transformações é intrínseco o desenvolvimento de novas formas de sociabilidades compatíveis com a mutação dos valores: a livre associação de indivíduos em salões literários, tertúlias, academias e outras associações - como lojas maçônicas -, com a finalidade de leitura e discussões orientadas pela razão. Destes espaços, resultaram, além de novas práticas de leitura, novas práticas sociais: associações livres, com definições sobre a periodicidade das reuniões, eleições e regras para o debate de ideias. Assim, trata-se de um processo de transformação mediado pelo exercício da leitura, discussões e liberdade de expressão. Daí a elaboração do ideal de homem, de sociedade e de política, resumida na ideia de sociedades contratuais igualitárias formadas por indivíduos livremente associados, com um poder saído do consenso da própria associação e submetido à vontade de seus membros. ${ }^{4}$ Em comparação a este ideal, as sociedades tradicionais de tipo estamental, baseadas em hierarquias, fundadas na tradição e na ideia de providência divina, representavam um sistema a ser alterado. Tais transformações dizem respeito, de

\footnotetext{
${ }^{3}$ Para análise da dinâmica interna do Iluminismo e seu impacto sobre as revoluções do século XVIII: KOSELLECK, Reinhart. Crítica e Crise: uma contribuição à patogênese do mundo burguês. Rio de Janeiro: EdUERJ - Contraponto, 1999.

${ }^{4}$ SILVA, Renán. Prácticas de lectura, ámbitos privados y formación de un espacio público moderno. In.: GUERRA, François-Xavier; LEMPÉRIÈRE, Annick. Los espacios públicos em Iberoamérica. México D.F.: Fondo de Cultura Económica, 1998, p. 80-102; GUERRA, François-Xavier. Modernidad e Independencia. Ensayos sobre las revoluciones hispânicas. México: Ed. Mafre e Fondo de Cultura Económica, 1993, p. 21 et seq.
} 
modo simultâneo e segundo modalidades específicas e comuns, tanto às sociedades europeias quanto às suas congêneres coloniais.

No decorrer do século XVIII, os princípios iluministas - segundo os quais as ações do homem deveriam ser guiadas pela razão - foram utilizados na formulação de projetos com o objetivo fundamental de reformas práticas em diferentes esferas dos governos absolutistas ibéricos a fim de torná-los, política e administrativamente, mais eficientes e racionais. Assim, uma parte de suas elites dirigentes era ilustrada e profundamente adepta da monarquia - para esta, condição fundamental das reformas desejadas. Na prática - conforme assinalado por Guerra -, embora as contraposições representem um esquema genericamente correto, a simples oposição entre Absolutismo e Iluminismo não pode ser tomada como suficiente. Em vários setores, por boa parte do século XVIII, adeptos do reformismo ilustrado compartilhavam espaço e a mesma hostilidade aos privilégios, ao conceito unitário de soberania e à ideia de uma relação binária sem intermediários entre poder e indivíduos. ${ }^{5}$

Ao tratar desta relação entre Absolutismo e o novo ideário setecentista, Reinhart Koselleck assinala que a situação de dificuldade de partes do sistema absolutista no século XVIII - Estados endividados, sem condição de vitórias em caso de guerras e que não conseguiam exercer uma administração eficiente em suas colônias -, criou condições para que estes Estados se aliassem aos ideais iluministas e, esta "aliança" permitira o desenvolvimento político do Iluminismo. ${ }^{6}$ Assim, segundo o autor, o movimento iluminista desenvolveu-se politicamente a partir do absolutismo. "No início como sua consequência interna, em seguida como sua

\footnotetext{
${ }_{6}^{5}$ GUERRA, François-Xavier, Modernidad e Independencia, op. cit., p. 25 et seq.

${ }^{6}$ O autor trata mais especificamente da perda de prestígio do Estado francês, cada vez mais endividado, enquanto a prosperidade da burguesia era crescente. KOSELLECK, Reinhart. Crítica e Crise: uma contribuição à patogênese do mundo burguês, op. cit.
} 
contraparte dialética e como inimigo que preparou sua decadência". ${ }^{7}$ Dessa maneira, os Estados absolutistas teriam condicionado a gênese do iluminismo e, este último, a gênese da revolução.

Trata-se, portanto, de uma "época marcadamente híbrida entre práticas e valores ainda consagrados ao que passava a se chamar de Antigo Regime, e outros que se pretendiam modernos". 8

Neste contexto, Portugal e Espanha, em grave crise econômica, e numa situação periférica no cenário internacional - dominado por Grã-Bretanha e França -, adotaram políticas reformistas pautadas pela racionalidade ilustrada. Realizaram reformas político-administrativas, educacionais, militares, recrudesceram os sistemas de tributação, fomentaram o aumento da produção e exportação dos gêneros coloniais. Medidas que aumentaram as tensões nas respectivas possessões ultramarinas e, se mostraram insuficientes para a reversão do quadro crítico em que as metrópoles se encontravam. $^{9}$

Portanto, inseridos em contextos amplos e dinâmicos, os estados ibéricos compartilham transformações gradativas, mas bastante aceleradas, na qual agrupamentos privados desenvolvidos sob o signo de novas práticas de sociabilidade - baseadas em leituras, debates e liberdade de crítica progressivamente politizada -, estabeleceram novas formas de comunicação, novos espaços de circulação de ideias, a transformação e criação de conceitos, promovendo o desenvolvimento de uma esfera crítica do poder público.

\footnotetext{
${ }^{7}$ Ibdem, p.19

${ }^{8}$ MOREL, Marco; BARROS, Mariana Monteiro. Palavra, imagem e poder. O surgimento da imprensa no Brasil do século XIX. Rio de Janeiro: DP\&Editora, 2003, p. 11.

${ }^{9}$ NOVAIS, Fernando A.. Portugal e Brasil na crise do antigo sistema colonial (1777-1808). $4^{\circ}$ ed., São Paulo: Hucitec, 1986; HALPERIN DONGHI, Tulio. Reforma y disolución de los imperios ibéricos 1750-1850. Madrid: Alianza Editorial, 1985.
} 
Nestas circunstâncias, a concepção do termo revolução - conceito-chave para o entendimento dessa conjuntura -, ainda em construção no universo linguístico do período, permitia apropriações com sentidos diversos. No mundo ibérico, estas utilizações diversas do vocábulo revolução refletiam o caráter multifacetado, instável e imprevisível do cenário político que era experimentado, apreendido e comunicado por seus protagonistas, frequentemente com dificuldade de precisão. A esfera dos discursos, portanto, é espaço de grande importância para compreensão do delineamento das novas identidades políticas, do entendimento acerca das imagens criadas pelos agentes destes processos, sobre si mesmos, e sobre o contexto no qual estão inseridos. Além, claro, de fornecer ferramentas de ação política concreta.

Para uma análise ampla dessa esfera, há que se ter em conta a formulação da ideia de opinião pública, que também tem sua gênese no século XVIII, quando começa a ocupar espaço nas reflexões políticas. Embora com precursores ilustres como Maquiavel, Montaigne, Pascal e Locke, foi Rousseau quem determinou seu lugar na sociedade política. Sendo a quarta lei na divisão das leis fundamentais, a opinião, segundo este filósofo, promovia a verdadeira constituição do Estado, sendo considerada mais poderosa que os próprios costumes. ${ }^{10}$

Espaço anônimo que rompe com a ideia do reservado ou secreto, mas que não exclui o privado. Ao contrário, “o espaço privado alarga-se por força própria em espaço público, e é somente no espaço público que as opiniões privadas se manifestam como lei". ${ }^{11} \mathrm{Na}$ sua origem, destinado ao debate de questões estéticas, científicas e literárias, esse espaço foi gradativamente ampliado ao campo político,

\footnotetext{
${ }^{10}$ Sobre opinião pública: BONAVIDES, P.. Ciência Política. Rio de Janeiro: Forense, 1983, p. 564572; HABERMAS, J.. Historia y critica de la opinión pública. México: Ediciones G. Gili, 1986, p. 6593; MOREL, Marco; BARROS, Mariana Monteiro. Palavra, imagem e poder, op. cit.; GUERRA, François-Xavier; LEMPÉRIÈRE, Annick. Los espacios públicos em Iberoamérica, op. cit.

${ }^{11}$ KOSELLECK, Reinhart. Crítica e Crise: uma contribuição à patogênese do mundo burguês, op. cit., p. 52 .
} 
tornando-se veículo pelo qual a "modernidade" teria extrapolado as esferas dos ideais e promovido mudanças significativas na relação entre Estados e sociedades; consequentemente, promoveria a alteração gradativa de práticas sociais e políticas de grande parte da Europa - e por conseguinte das suas respectivas possessões. Com o decorrer dessas mudanças, as projeções para o porvir se desvinculavam cada vez mais das experiências até então conhecidas. Os acontecimentos do passado já não eram suficientes para fundamentar as expectativas geradas por estas novas referências. Assim, em Koselleck, a ideia de modernidade passa a ser vinculada à noção do novo tipificado por uma tendência à inversão de prioridade entre passado e futuro como cerne das visões de história e de mundo -, caracterizada pela ruptura, e não pela continuidade. $^{12}$

Para viabilização e fomento deste espaço do juízo coletivo era imperativo o aprimoramento da comunicação. O aumento da circulação de impressos e, principalmente, a expansão da imprensa periódica desempenharam papel protagonista neste sentido. Além de promover a observação e interação desses espaços por seus próprios participantes. Dessa maneira, no início do século XIX, os periódicos, já estabelecidos como meio de informações científicas e artísticas, em vários lugares, passaram a constituir-se em instrumento de fomento político.

Como veículo de projetos políticos, a imprensa contribuiu para a formatação de identidades políticas e culturais, intervindo nos processos e episódios, em vez de dignar-se apenas ao simples reflexo dos fatos. Ofereceu os recursos técnicos necessários para uma difusão mais acelerada de princípios e proposições práticas, promovendo a identificação de grupos que passam a compartilhar expectativas em

\footnotetext{
${ }^{12}$ KOSELLECK, Reinhart. 'Espaço de experiência' e 'horizonte de expectativa': duas categorias históricas. In.: Futuro Passado. Contribuição à semântica dos tempos históricos. Rio de Janeiro: Contraponto, Editora PUC-Rio, 2006, p. 305-329.
} 
torno de ideais propagados. ${ }^{13}$ A criação desta noção de pertencimento de um projeto maior foi condição importante - mas não mecânica - para que dos processos de independência da América ibérica resultassem os fenômenos que delas resultaram. De muitas maneiras distintas, foram necessárias formas de identificação coletiva que possibilitassem a adesão a projetos políticos que até então não existiam. ${ }^{14}$

Nesta conjuntura, a produção periódica, suporte material da esfera pública, gera e atende demandas, num processo contínuo de circulação de informações e ideias, com considerável poder de alcance, tanto pelo número, quanto pela variedade do público, pois que os escritos podiam atravessar fronteiras, criando espaços de influências mútuas. Os impressos "transpunham mares e faziam viajar seus leitores". ${ }^{15}$ Importante esclarecer que, neste contexto, a ideia de público atingido pela produção periódica não se restringe aos letrados. A leitura nos tempos do Antigo Regime não consistia unicamente numa atitude individual e privada, era praticada também como atividade coletiva, promovendo interseções entre expressões orais e escritas. $^{16}$

A circulação de periódicos promoveu o alargamento desses espaços públicos de discussões e influências, extrapolando às fronteiras dos Estados, como provam as

\footnotetext{
${ }^{13}$ ANDERSON, Benedict. Nação e Consciência Nacional. São Paulo: Ática, 1989 - capítulos 2 ao 4; MOREL, Marco; BARROS, Mariana Monteiro de. Palavra, imagem e poder. O surgimento da imprensa no Brasil do século XIX, op. cit.; Marco MOREL. Independência no papel: a imprensa periódica. In.: JANCSÓ, István (org.), Independência: História e Historiografia. São Paulo: Hucitec Fapesp, 2005, p. 617-636.

${ }_{14}$ PIMENTA, João Paulo Garrido. O Brasil e a América Espanhola (1808-1822). São Paulo: FFLCHUSP, Tese de Doutorado, 2003.

${ }^{15}$ MOREL, Marco; BARROS, Mariana Monteiro de. Palavra, imagem e poder. O surgimento da imprensa no Brasil do século XIX, op. cit., p.16. Aqui cabe citar as correspondências do comerciante José Ignácio de Pombo ao naturalista José Celestino Mutis (1803-1807), onde o primeiro, do Porto de Cartagenas de Índias, em Nova Granada, versava sobre notícias dos mais diversos periódicos: Gazetas de Madri, Berlim, Paris, Londres, Havana e Estados Unidos. Citado por SILVA, Renán. Prácticas de lectura, ámbitos privados y formación de un espacio público moderno. In.: GUERRA, François-Xavier; LEMPÉRIÈRE, Annick. Los espacios públicos em Iberoamérica, op. cit., p. 103-106.

${ }^{16}$ MOREL, Marco; BARROS, Mariana Monteiro de. Palavra, imagem e poder. O surgimento da imprensa no Brasil do século XIX, op. cit., p. 45-46. PÉREZ VILA também assinala as leituras coletivas como multiplicadoras dos conteúdos difundidos por periódicos na América hispânica. PÉREZ VILA, Manuel. Bolívar y el periodismo. In.: Bolivar y el periodismo: Seminário Latino-americano, 22 a 24 de junho de 1983. Caracas: Publicaciones del Congreso de la Republica de Venezuela, p. 287-296.
} 
publicações periódicas da América e Europa, que demonstravam interesses mútuos, frequentemente comentando ou reproduzindo textos reciprocamente. Esse é precisamente o caso do que aqui nos interessa mais de perto.

O debate estabelecido entre o Correio Braziliense e o Correo del Orinoco, entre 1817 e 1820, teve como eixo central os acontecimentos da capitania lusoamericana de Pernambuco em 1817. Ele nos conduz à ideia de revolução como conceito fundamental para o entendimento daquela conjuntura, permitindo-nos, ademais, vislumbrar a interação e influência mútua entre dois de seus quadrantes: Brasil e Venezuela.

Antes de proceder à análise das fontes realizamos uma apresentação das mesmas no contexto do desenvolvimento da imprensa na Capitania-Geral da Venezuela e no Brasil, situando ambos os espaços no quadro geral da imprensa na América ibérica. Na sequência, no segundo capítulo, apresentamos um panorama da crise política dos impérios ibéricos no período antecedente a 1817 - ano do movimento republicano em Pernambuco, mote do debate analisado - tendo em vista o entendimento dos processos que determinaram o contexto no qual foram elaborados os discursos. No capítulo subsequente, analisamos as circunstâncias específicas do ano de 1817: os eventos de Pernambuco no lado lusitano da América, e a renovação dos esforços voltados para a concretização do projeto republicano na Venezuela, ou seja, momento de grande relevância nos desdobramentos dos processos que culminaram nas respectivas independências políticas. No quarto e último capítulo, apresentamos um breve estudo semântico do termo chave do debate- revolução - que nos forneceu ferramenta fundamental para finalmente realizar o estudo da contenda entre os periódicos. 


\section{CAPÍTULO 1: A IMPRENSA NA AMÉRICA IBÉRICA}

A arte da impressão foi introduzida em território americano no século XVI, poucas décadas após a chegada dos europeus. México (1539) e Lima (1580) foram as primeiras localidades da América Ibérica a usufruir de serviços tipográficos. Inicialmente, o ato de imprimir era voltado para a promoção da catequese. A produção periódica foi iniciada somente no século XVIII como meio de divulgação e fomento de ideias sobre arte, sociedade e política, contribuindo para difusão dos novos referenciais que se desenvolviam no velho continente e, em decorrência, em todo o território dos impérios ibéricos. Além de ser utilizada na difusão de conteúdos religiosos e de formalidades relativas à gestão imperial.

Em comparação ao restante da América, tanto nos territórios luso- americanos como na Capitania-Geral da Venezuela, a imprensa periódica, inaugurada em 1808 , iniciou-se tardiamente. A Gazeta de México y Noticias de Nueva España, foi o primeiro periódico hispano-americano, iniciado em 1722. Ainda no século XVIII, seguem a Gazeta de Goathemala (1729), Gazeta de Lima (1743), Gazeta de La Havana (1764) e, posteriormente, El Periódico de La Habana (1790), El Diário de Lima (1790), Mercúrio Peruano e Papel Periódico de Santa Fé de Bogotá (1791), e Primicias de la Cultura de Quito (1792). Na região do Prata, em 1801, foi lançado o Telégrafo Mercantil, mesmo ano de o Correo, Curioso, Erudito, Económico y Mercantil em Santa Fé de Bogotá, e, no ano seguinte, Semanário de Agricultura, em Buenos Aires. Em 1806, foram lançados o Redactor Americano em Santa Fé de Bogotá, a Gazeta de Puerto Rico em 1807 e, no mesmo ano, em Montevidéu, o Estrella del Sur. Em 1808, ano no qual em Bogotá é lançado mais um periódico - o Semanário del Nuevo Reino de Granada -, a imprensa na Venezuela é inaugurada 
com a Gazeta de Caracas $^{17}$ e, no Brasil, com a Gazeta do Rio de Janeiro. ${ }^{18}$

Mesmo que tardia em relação as demais localidades americanas, a imprensa periódica no Brasil, e na Venezuela, surgiu num momento de grande importância para o delineamento das políticas futuras nesses territórios. A nova conjuntura, estabelecida na Europa pelas ações napoleônicas, obrigou as monarquias ibéricas ao reordenamento de suas relações com a América, num processo de transformações aceleradas, no qual o periodismo foi protagonista na difusão de informações e ideias, conectando, em muitos casos, localidades distintas.

\section{1- A imprensa na Venezuela e o Correo del Orinoco}

Francisco de Miranda ${ }^{19}$ foi o primeiro a concretizar o funcionamento de uma imprensa voltada para a Capitania-Geral da Venezuela. A bordo da embarcação Leander, Miranda comandou a expedição rumo aquele território - iniciada em fevereiro de 1806 a partir de Nova Iorque -, e coordenou os trabalhos de impressão de

${ }^{17}$ ROSAS MARCANO, Jesús; SANOJA HERNÁNDEZ, Jesús; FRANCISCO LIZARDO, Pedro. Papel de la Prensa en la Lucha por la Independência de Venezuela. In.: Bolívar y el periodismo, Seminário Latino-americano, 22 a 24 de junho de 1983, op. cit., p. 237 et seq.

${ }^{18}$ SODRÉ, Nelson Werneck. História da imprensa no Brasil. $4^{\mathrm{a}}$ ed. Rio de Janeiro: Mauad, 1999; MOREL, Marco; BARROS, Mariana Monteiro. Palavra, imagem e poder. O surgimento da imprensa no Brasil do século XIX, op. cit.; SILVA. Maria Beatriz Nizza da. A Gazeta do Rio de Janeiro (18081822). Cultura e sociedade. Rio de Janeiro: Ed. UERJ, 2007.

19 Francisco de Miranda (1750-1816), o "Precursor" da independência da Venezuela, como ficou conhecido por parte da historiografia daquele país, era natural de Caracas. Aos 21 anos, comprou na Espanha o título de capitão e iniciou carreira militar na África. Deixou o exército espanhol com a patente de tenente coronel e foi para os Estados Unidos, onde passou 18 meses estudando o processo de independência estadunidense. Miranda era tido como homem de vasta cultura e grande curiosidade. Por quatro anos (1785-1789) viajou pela Europa antes de alistar-se no exército francês - durante a Revolução - chegando ao posto de marechal de campo. Foi preso sob a acusação de pertencer ao Partido dos Girondinos. Após a saída da prisão, deixou a França e circulou pela Inglaterra e Estados Unidos tentando angariar auxílio para uma ação que visava promover a independência política da Venezuela. Conseguiu recursos para realizar duas incursões na costa venezuelana em 1806, sendo repelido pelas forças espanholas. Retornou a Londres com o objetivo de recompor forças para uma nova investida. Seus planos foram adiados com a suspensão da promessa de apoio britânico quando do início dos conflitos deflagrados por Napoleão. Anos mais tarde, encontrou-se com Simón Bolívar, que o convenceu de que sua experiência era necessária para a nova fase política da Venezuela. Diccionario de historia de Venezuela, tomo 3. Caracas: Fundación Polar, 1997; MIJARES, Augusto. El Libertador. Caracas: Academia Nacional de la Historia - Ediciones de la Presidencia de la República, 1987, p. 120-170. 
uma oficina instalada no convés do navio. Dali imprimiram-se ofícios e proclamações, explicitando os propósitos de sua empreitada, destinados aos "amigos e compatriotas" e a "todas as partes do mundo tão logo chegassem ao seu destino". 20

Porém, o primeiro mecanismo de impressão efetivamente instalado na Venezuela foi levado a Caracas por Mateo Gallagher e Jaime Lamb em 1808. ${ }^{21}$ A arte de imprimir foi inaugurada no território da Venezuela no dia a 24 de outubro daquele ano com a publicação do primeiro número da Gazeta de Caracas. $^{22}$

Fundada no ano em que Napoleão invadiu a Espanha - obrigando à renúncia o rei Carlos IV e seu herdeiro, Fernando VII, provocando a reação da população espanhola em defesa dos direitos do monarca, e a formação de juntas de governo espalhadas por todo o território na busca da manutenção da ordem golpeada -, a Gazeta de Caracas era publicada como órgão oficial do governo espanhol daquela capitania, praticamente como uma extensão da Gazeta de Madrid, sua principal fonte. Apesar de seu primeiro redator, Andrés Bello, ser natural da Venezuela, neste primeiro momento, o semanário, convertido em instrumento de defesa da monarquia espanhola, não trazia muitas notícias locais. Impresso até janeiro de 1822, o periódico sofreu todos os revezes do processo que culminou na independência do país: passando sucessivamente de mãos realistas a republicanas, e vice-versa, até sua extinção pelo

\footnotetext{
${ }^{20}$ FEBRES CORDERO, Julio. Historia de la Imprenta y del Periodismo en Venezuela (1800-1830). Caracas: Banco Central de Venezuela, 1974, p. 15-47.

${ }^{21}$ A origem do equipamento já foi tema de polêmica na historiografia venezuelana: uma parte dele seria o sobressalente da oficina de Gallagher em Trindad e a outra, adquirida em Nova Granada. Alguns historiadores acreditam na hipótese de que a imprensa de Gallagher em Trindad fosse a mesma utilizada por Miranda anos antes, e negociada diretamente entre ambos. É o que afirmaram Aristides Rojas, Ricardo Becerra e outros contestados por Pedro Grases. Febres Cordero fez um balanço da discussão defendendo a primeira hipótese: FEBRES CORDERO, Julio. Em Historia de la Imprenta y del Periodismo en Venezuela (1800-1830), op. cit.

${ }^{22}$ No ano de 1815 alterou-se a grafia do título do periódico de Gazeta para Gaceta.
} 
governo independente, que a substituiu como órgão oficial por uma nova publicação, Íris de Venezuela. ${ }^{23}$

Em janeiro de 1810, a invasão francesa da Andaluzia provocou a dissolução da Junta Central de Governo, aprofundando a crise de sucessão da autoridade real espanhola. Assim como em outros territórios hispano-americanos, em resposta à instabilidade da situação metropolitana, constituiu-se em Caracas, no dia 19 abril do mesmo ano, uma "Junta Suprema de Gobierno Defensora de los Derechos del Rey Fernando VII". Na prática, tal iniciativa representou o rompimento com o governo estabelecido na metrópole. A Gazeta passou então a instrumento desta Junta até julho de 1811, quando se tornou veículo oficial da Primeira República da Venezuela.

A inquietação política e o clima de relativa autonomia em relação a Espanha, propiciaram a proliferação de impressos e novos periódicos e, com eles, a veiculação de discursos opositores ao governo metropolitano - estes, em pouco tempo, transformaram-se em discursos pró-independência. Em Caracas, foram criados quatro novos periódicos - quantidade bastante relevante para o período -, a maioria teve circulação relativamente breve, mas o suficiente para efervescer ainda mais os embates políticos na Venezuela. No mês de novembro de 1810 inaugurou-se o Semanário de Caracas, editado por Miguel José Sanz e José Domingos Díaz. ${ }^{24}$ Em janeiro do ano seguinte, foram lançados El Patriota de Venezuela e o Mercúrio

\footnotetext{
${ }^{23}$ Para detalhamento sobre as diferentes orientações editoriais: Gaceta de Caracas. Edição fac-similar em comemoração ao Bicentenário de Simón Bolívar. Caracas: Biblioteca de la Academia Nacional de la Historia, 1983, estudo prelminar; ROSAS MARCANO, Jesús; SANOJA HERNÁNDEZ, Jesús; FRANCISCO LIZARDO, Pedro. Papel de la Prensa en la Lucha por la Independencia de Venezuela. In Bolivar y el periodismo, op. cit.

${ }^{24} \mathrm{~A}$ união dos dois editores, com posicionamento político distintos, não durou muito tempo. O último número do Semanário de Caracas foi publicado em 21 de julho de 1811. A colaboração de Díaz - que anos mais tarde, frente à Gazeta de Caracas, tornar-se-ia o principal opositor de Bolívar no campo das ideias -, era resumida aos temas de agricultura, economia e estatística. PINO ITURRIETA, Elias A. La mentalidade venezolana de la emancipacion (1810-1812). Caracas: Universidad Central de Venezuela, 1971, p. 104-118; RODRÍGUEZ, Manuel Alfredo. El Correo del Orinoco, periódico de la emancipación americana. Caracas: Instituto Nacional de cultura y Bellas Artes, s.d., p. 126.
} 
Venezolano. O primeiro, era órgão oficial da Sociedade Patriótica, ${ }^{25}$ publicado por iniciativa de Antonio Muñoz Tebar e Vicente Salias. O outro, fundado e redigido por Francisco Isnardi, era instrumento criollo de contestação ao governo espanhol. ${ }^{26}$ Sua existência foi abreviada para que Isnardi assumisse a redação do periódico oficial do Primeiro Congresso da Venezuela, El publicista de Venezuela, inaugurado em 4 de julho de $1811^{27}$

A produção periódica não era exclusividade da capital. Em Cumaná, a segunda cidade da Venezuela a gozar dos benefícios da tipografia, publicou-se em outubro de 1811 o primeiro número do El Venezolano, que segundos os editores, tinha o objetivo de "proseguir el arte liberal del impreso". ${ }^{28}$ Em Valencia e Maracay também se imprime a partir de 1812 e, no ano seguinte, na pequena Guiria. ${ }^{29}$

Em outubro de 1812 iniciou-se o segundo período realista da Gazeta de Caracas, até a entrada de Bolívar na capital da província, em agosto do ano seguinte, quando recuperou o governo e a sua imprensa. Ficou sob o domínio do grupo republicano também por pouco tempo. A entrada de José Tomás Boves em Caracas no mês junho de 1814 devolve o periódico às mãos realistas pela terceira vez - o primeiro número desta nova fase publicado em $1^{\circ}$ fevereiro de 1815 -, sendo convertido em instrumento de defesa da ordem colonial, e de propaganda política

\footnotetext{
${ }^{25}$ A "Sociedade Patriótica de Agricultura e Economia" fundada por decreto da Junta de Governo, em 14 de agosto de 1810, com a função de centro de estudo para o desenvolvimento material do país, após junho de 1811 quando Miranda assume sua presidência, foi convertida na principal organização política onde os favoráveis pela independência da Venezuela se articulavam. El Patriota de Venezuela foi publicado até janeiro de 1812. Sobre Sociedade Patriótica: PACHECO TROCONIS, Germán. La sociedad económica de Amigos del País de Caracas, el conocimiento agronómico y el progreso agrícola (1830-1844). In.: Revista Tierra Firme, jul. 2003, vol. 21, n. ${ }^{\circ}$ 83, p. 335-350. In.: http://www2.scielo.org.ve/scielo.php?script=sci_arttext\&pid=S0798$29682003000300006 \& \operatorname{lng}=\mathrm{es} \& \mathrm{nrm}=\mathrm{iso}>$. ISSN $0798-2968$.

${ }^{26} \mathrm{O}$ terceiro, e último número, foi publicado em maio de 1811. Sobre El Patriota de Venezuela e o Mercúrio Venezolano: PINO ITURRIETA, op cit., p.127-136 e p. 93-104, respectivamente.

${ }^{27}$ Semanário publicado até novembro do mesmo ano. PINO ITURRIETA, op cit., p.118- 126.

${ }^{28}$ Citado por FEBRES CORDERO, Julio, op. cit, p.75.

29 Nestas últimas localidades os impressos produzidos não eram periódicos. Vide FEBRES CORDERO, op. cit, p. 75-96.
} 
contra o movimento de independência, permanecendo assim até junho de 1821, quando foi retomado pelo Governo republicano, que o extinguiu no ano seguinte.

A imprensa realista não contou somente com a Gazeta de Caracas. Domingo de Monteverde - responsável pela campanha militar que terminaria com a queda da Primeira República da Venezuela em 1812 -, usou a imprensa de Valencia para publicação de boletins, assim como outras oficinas locais foram utilizadas pelas forças de Espanha. Em Cumaná, por exemplo, publicaram El tapabocas, no ano de 1813. ${ }^{30}$ Além da oficina portátil utilizada pelo general Pablo Morillo durante as expedições iniciadas em 1815 com o propósito de reconquistar a Venezuela à Espanha. $^{31}$

Assim, em princípios do século XIX a imprensa na Venezuela, como em toda a América hispânica, estava convertida em uma poderosa arma de persuasão política tantos dos ideais do movimento pela independência, quanto do contrário. Os combates no campo ideológico e político eram tão acirrados quanto o embate das armas nos campos de batalha. A desqualificação moral do inimigo era tática imprescindível nesta guerra, na qual "convencer era tão importante quanto vencer". ${ }^{32}$ Assim, entre os esforços contra as forças realistas, foi inaugurado, por ordem de Simón Bolívar, o Correo del Orinoco em junho de 1818.

Publicado na cidade de Angostura - atual Ciudad Bolívar -, onde em 1818 estava a base das forças republicanas durante a Guerra pela Independência da Venezuela, este semanário de quatro páginas teve 128 números, entre junho de 1818 e

\footnotetext{
${ }^{30}$ Sobre a imprensa realista na Venezuela: FEBRES CORDERO, op. cit., p. 97-99.

${ }^{31}$ SEGUNDO SÁNCHEZ, Manuel. La imprenta de la Expedición Pacificadora, 1916. In.: Gaceta de Caracas, op. cit., 1983, volume 7, estudo preliminar.

${ }^{32}$ Formulação utilizada por PÉREZ VILA, Manuel. Bolívar y el periodismo. In.: Bolívar y el periodismo, op. cit., p. 287-296.
} 
março 1822 , com mais cinco edições extraordinárias, não numeradas. ${ }^{33}$ Contou com cinco redatores, três impressores e dezesseis colaboradores, o que torna quase impossível a tarefa de identificação dos artigos não assinados e aqueles assinados por pseudônimos. ${ }^{34}$ Colaboravam também correspondentes, como Guillermo Whiter, “inglês ilustrado, informante ponderado dos acontecimentos da política internacional europeia, particularmente daqueles relacionados com a formação das novas nacionalidades". 35 Durante os quatro anos de existência do Correo del Orinoco, embarcações carregadas com seus exemplares partiam regularmente de Angostura em direção as Antilhas - que junto à Venezuela e Nova Granada formavam a principal zona de sua difusão - e dali eram expedidos principalmente para a América do Norte e Europa. $^{36}$

Voz do movimento pela independência política da projetada "República da Colômbia”, que Bolívar propunha criar com as antigas colônias do Vice-Reino de Nova Granada, ${ }^{37}$ o Correo del Orinoco era uma extraordinária fonte de informação e vinculação ideológica com movimentos análogos, à medida que reproduzia trechos de outros periódicos da América e da Europa com o objetivo de conectar sua causa às que lhe eram interessantes. ${ }^{38}$ Como arma tática de informação, o periódico era

\footnotetext{
${ }^{33}$ Em quase quatro anos a publicação sofreu 18 pequenas interrupções (de duas a quatro semanas), mais duas maiores: entre 21 de novembro de 1818 a 30 de janeiro de 1819 e, em 1821, de 18 de agosto a 29 de novembro.

${ }^{34}$ As colunas intituladas "Cartas de um Patriota" são atribuídas ao Dr. Cristóbal de Mendoza, colaborador do jornal a partir de 1820. Ver CORREA, Luis; DUARTE LEVEL, Lino. La doctrina de la revolución emancipadora en el Correo del Orinoco. Caracas: Academia Nacional de História, s.d., p. 107-136. Uma breve biografia dos redatores e principais colabores foi elaborada por ALFREDO RODRIGUEZ, Manuel. El Correo del Orinoco, periódico de la emancipación americana, op. cit., p. 63-87. A mesma obra também oferecer um balanço de estudos que identificaram a colaboração pessoal de Bolívar através de texto assinados com pseudônimos, p. 49-52.

${ }^{35} \mathrm{Ibdem}$, p. 32.

${ }^{36}$ RODRÍGUEZ, Manuel Alfredo. El Correo del Orinoco, periódico de la emancipación americana, op. cit., p. 114-117.

${ }^{37}$ O Vice-Reino de Nova Granada era formado por Nova Granada, pela Capitania Geral da Venezuela e Real Audiência de Quito. Seu território correspondia ao que atualmente está dividido entre Colômbia, Venezuela, Equador e Panamá.

${ }^{38}$ ANGELES SERRANO, María de los; VENEGAS, Asalia. El Correo del Orinoco: un Instrumento poderoso en la Independencia de América Latina. In.: Bolívar y el periodismo, op. cit, p. 272-273.
} 
responsável por difundir entre compatriotas e estrangeiros os ideais e propósitos do movimento republicano, assim como disseminar uma ideia positiva dos resultados das suas empreitadas.

Além de ocupar-se em difundir os sucessos da empreitada pela independência da Venezuela, como um dos elementos principais na estratégia de guerra, o periódico era responsável pela defesa do movimento republicano contra as ofensivas de José Domingo Díaz ${ }^{39}$ veiculadas pela Gaceta de Caracas. Díaz, redator da Gaceta, era ferrenho defensor e apologista do antigo regime, sendo assim o principal opositor da causa republicana diante da opinião pública. Nas palavras de Manuel Alfredo Rodríguez, Domingo Díaz “com a pluma foi para causa realista na Venezuela o que Boves foi com a espada". ${ }^{40}$ Tentou disseminar em seus escritos a ideia de uma ruptura violenta da "felicidade americana" provocada pelo movimento de 1810. Eram comuns argumentos como estes publicados na Gazeta de Caracas em abril de 1815:

"Venezuela fué feliz mientras fuéron constantes estos principios; mientras al nombre de su Rey temblaban los perversos, y se llenaban de respeto los honrados; mientras su voluntad y sus órdenes eran ciegamente obedecidas (...)

\footnotetext{
${ }^{39}$ José Domingo Díaz nasceu em Caracas no ano de 1772. Filho de família não nobre, mas com confortável condição financeira, cursou Filosofia, e se formou pela Faculdade de Medicina da Real e Pontifícia Universidade no ano de 1794. Em 1809 tornou-se sócio da Academia da Corte de Madri. Assim como sua carreira burocrática, a produção intelectual foi fecunda - realizou tratamentos experimentais contra a lepra, traduziu a obra do estadunidense Benjamin Rush, sobre febre amarela, além de realizar estudos sobre doenças endêmicas e a vacina anti-varíola. Sua atividade política foi intensa e controvertida, distanciando-se gradativamente dos mantuanos - assim chamados porque suas mulheres tinham o privilégio de usar o manto -, grandes fazendeiros escravistas, um grupo socialmente distinto entre os criollos. O principal atrito se deu quando da sua nomeação, em 1810, pela Junta de Sevilha, para o cargo de controlador-inspetor de Hospitais, não reconhecida pelos criollos da Junta Governativa de Caracas formada em abril daquele ano. Seu trabalho realizado no Semanário de Caracas, destacou-se pelas criticas reformistas ao sistema de educação, em especial ao atraso dos estudos de medicina. Após o fracasso da Primeira República, passou a militar fortemente contra o governo proposto por seus conterrâneos republicanos, tornando-se uma das principais vozes realistas na Venezuela via Gaceta de Caracas. Ver PINO ITURRIETA, Elias. In.: Gaceta de Caracas, op. cit, volume 6, estudo preliminar.

${ }^{40}$ RODRÍGUEZ, Manuel Alfredo, op. cit., p.130.
} 
Entonces Venezuela era feliz; sus campos la llenaban de riquezas: su población se doblaba; su opulência volaba hácia un término inconcebible; la paz reynaba en las famílias; los menores crímenes espantaban, y los mayores se desconocían. El gênio feroz de la discórdia civil no había roto los lazos de su asociación ni en los caminos, ni en los pueblos, ni en los campos publicaban sus estragos los esqueletos de nuestros hermanos. Todo era paz, unión, tranquilidad y abundancia, nacidos exclusivamente del amor à su Rey, y lla obediência à las leyes.

Un corto número de hombres perversos, ignorantes, presumidos y llenos de todos os vícios se apoderaron del gobierno y echaron llos fundamentos de la destruccion de Venezuela". ${ }^{41}$

Em seu discurso propagandístico, não poupou acusações e ofensas pessoais a Simón Bolívar, expoente máximo do processo pró-independência:

"Si à los pueblos de Venezuela ultrajados y destruídos por el mas brutal de todos os déspotas, por sus colegas y por su gavilla, les he presentado sucesivamente los proyectos las maquinaciones, y los fines que tuveron, y à que se dirigiéron. Si han visto ya al Inhumao, cobarde, cruel, insensato, pueril, orgulloso, pérfido e ignorante, es necessário que acaben de conocerle, así para que se deteste su memoria, como para que se aprecie mas el bien que se posee". ${ }^{4}$

\footnotetext{
${ }^{41}$ Gaceta de Caracas, n. ${ }^{\circ}$ 10, 05 de abril de 1815, op. cit., vol. 4, p. 82-83.

${ }^{42}$ Gaceta de Caracas, n. ${ }^{\circ}$ 13, 26 de abril de 1815, op . cit., vol. 5, p. 109.
} 
Outro recurso recorrente era a exaltação das virtudes do rei espanhol em oposição à toda sorte de vícios atribuídas à Bolívar e ao movimento que comanda. Como podemos exemplificar com este trecho de 1815 :

"iQue contraste tan vergonzoso para los perversos que amando el desorden sieguen al Bárbaro y sus delírios! Baxo el falso título de su peculiar liberdad, y de necesidades del estado nuestra pátria fué robada por sus agentes, $\mathrm{y}$ nuestros compatriotas sacrificados à su ambición. Quedó destruído adonde quiera que alcanzó el contacto de su corrompido corazón: el honor, la hacienda y la vida desaparecieron, y Venezuela fué el teatro de la abominación mas escandalosa. (...)

Compatriotas: ved al Rey, su caráter paternal, y el amor con que nos distingue. El no exige de nosotros en recompensa, sino una ciega obediência á sus decretos; el debido respecto á sus autoridades; la maior sumisión á las leyes. Manda y quiere que vivamos en paz; que cumplamos nuestra respectivas obligaciones; que nos amemos mutuamente; que concurramos de buena fé á la gran obra de la tranquilidad y confianza pública; y que seamos todos sus hijos, todos españoles", 43

O Correo del Orinoco seguia a mesma tendência nas suas investidas contra a Gaceta de Caracas e o governo espanhol. Em agosto de 1818, ao refutar artigos de vários números do periódico opositor, usa os seguintes termos:

\footnotetext{
${ }^{43}$ Gaceta de Caracas, n. $^{\circ}$ 11, 12 de abril de 1815, op. cit., vol. 4, p. 95.
} 
"El redactor de la Gazeta de Caracas es veterano, no solo en mentir, sino en falsificar. Si antes ha vivido de su lengua, ahora vive de su pluma. Nadie extraña que un personaje tan ridículo y despreciable se haya proposto hacerse un nombre con su interminable charla de Sandeses y Chismes". 44

Três semanas depois, mais uma vez se defendendo contra as acusações veiculadas pela Gaceta de Caracas:

"Sin embargo de ser estos unos hechos de notoria evidencia, y que pueden atestiguar varios emigrados realistas que actualmente se hallan en las Antillas, y otros que regresaron a esta Capital, el impostor Gazetero o Goberno de Caracas ha tenido la infame desverguenza de asegurar con toda la firmeza propia del descaro que el venerable Prelado fue sacrificado escandalosamente por el General Arismendi. (...). Estaba reservado a los Españoles establecer una Gazeta, y Gazeta oficial, consagrada especialmente a la mentira, a la impostura, a toda espécie de calumnias y de falsedades, y burlarse del mundo civilizado, solo por el empeño estolido de degradarnos". ${ }^{4}$

Contudo, o periódico republicano impresso em Angostura não era arma apenas para defesa, mas também para o ataque. Era comum o uso dos termos tirania, despotismo e seus correlatos, ao se referir a Fernando VII e seu governo, constantemente responsabilizados pelas agruras americanas. Em julho de 1818, por exemplo, o Correo del Orinoco acusou os espanhóis por pertubarem "el orden en

\footnotetext{
${ }^{44}$ Correo del Orinoco n. ${ }^{\circ}$ 6, $1^{\circ}$ de agosto de 1818. In.: RIVAS MORENO, Geraldo (ed.). Correo del Orinoco - Angostura 1818-1821. Edicion Facsimilar. Bogotá: Fundación FICA, 1998, p. 24.

${ }^{45}$ Correo del Orinoco n. ${ }^{\circ}$ 9, 22 de agosto de 1818, op. cit., p. 36
} 
América, pues que ellos son los que vienen a violar, matar y robar, y como nosotros no sufrimos pacientemente el exercicio de estas costumbres Españolas, no tenemos orden". 46

A refutação e desmoralização da Gaceta de Caracas também era tarefa cumprida com frequência. Em abril de 1819, ao comentar dois números do periódico opositor, o Correo del Orinoco publicou que "Han llegado casualmente a nuestras manos los números 236 y 237 de esta graciosísima Gazeta, que como todas las de los Españoles de Fernando no llevan otro objeto que mantener los pueblos en la ilusión y en el error". 47

Assim, as batalhas nos campos das letras eram disputadas com o mesmo empenho dos exércitos em armas. Nesta guerra de ideias, a interceptação de documentos, para reproduções seguidas de contestações, era tática recorrente. Nas páginas do periódico de Angostura refutavam-se as notícias publicadas pelo exército espanhol sobre as derrotas republicanas, e vários ofícios do general espanhol realista Pablo Morillo eram reproduzidos sempre acompanhados de comentários, como esta nota do redator que acompanha um ofício do General ao Ministro da Guerra em Espanha, a 7 de março de 1818:

"Como estos son todos partes de los Cabecillos Españoles. Basta compararlos para convencerse de que son un texido de imposturas y falsedades, que solo merecen el desprecio de los que saben ler con juicio y reflexión. Señor Murillo, hasta para mentir se requiere arte, y sin ella jamás saldrá Vmd. de la clase de un embustero ordinario, que

\footnotetext{
${ }^{46}$ Correo del Orinoco n. ${ }^{\circ}$ 4, 18 de julho de1818, op. cit., p. 14.

${ }^{47}$ Correo del Orinoco n. ${ }^{\circ}$ 28, 24 de abril de 1819, op. cit., p. 109.
} 
se desmiente cada pase y se contradice si mismo. Veamos si esto es lo que Vmd. sucede en sus Ofícios". 48

O Correo del Orinoco cumpria ainda uma função normativa, veiculando atas, leis, proclamas, informando aos venezuelanos sobre as definições da República, sendo assim instrumento importantíssimo também nos esforços de unificação e centralização do governo republicano. Portanto, se o Correo del Orinoco não pode ser considerado fonte definitiva sobre o que realmente era a República da Venezuela no período nenhuma fonte o é -, é fonte imprescindível para se entender o que se projetava ser esta República.

O periódico de Angostura evidencia como um projeto republicano e independentista compreendia o alargamento de um espaço público de discussão e, como estava atento à importância da opinião pública. Como exemplificam o Boletim sobre a batalha de Boyacá, publicado também em inglês na edição de 19 de setembro de 1819 , e a edição extraordinária de 25 de julho de 1821 , noticiando a Batalha de Carabobo, publicado em três idiomas - espanhol, inglês e francês. ${ }^{49}$ Da mesma forma, a necessidade de refutar o Correio Braziliense sobre suas ideias de revolução, que, além da preocupação com o tema em si, indica interesse sobre as informações circulantes na vizinhança monarquista.

Em 1820, Bolívar partiu de Angostura para não mais retornar. O triunfo de seu exército em Carabobo, no ano seguinte, praticamente define a vitória do movimento

\footnotetext{
${ }^{48}$ Correo del Orinoco n. ${ }^{\circ}$ 5, 27 de julho de 1818, op. cit., p. 18.

${ }^{49}$ A Batalha de Boyacá - território colombiano limítrofe à Venezuela -, em 7 de agosto de 1819, foi crucial para a proclamação da República da Colômbia, em dezembro do mesmo ano. E, a vitória em Carabobo, no dia 24 de junho de 1821, decisiva para independência do território da Venezuela, quando o último dos grandes exércitos realistas foi derrotado. A partir deste momento, só ficaram algumas posições ilhadas derrotadas por Bermúdez em Cumaná - outubro de 1821-, pelo almirante Padilha na batalha naval de Maracaibo - 24 de julho de 1823 -, e por José Antonio Páez, com a captura do Forte de Porto Cabello, em 8 de Novembro de 1823. As edições que noticiaram as ditas batalhas. In.: Correo del Orinoco. op. cit., p. 157-159 e 449, respectivamente.
} 
pela independência da Venezuela, e assim a missão do Correo del Orinoco estava praticamente cumprida. Sua impressão foi interrompida por mais de três meses - 18 de agosto a 29 de novembro de 1821 - e, em março de 1822, foi oficialmente encerrada.

\section{2- A imprensa no Brasil e o Correio Braziliense}

O surto minerador no século XVIII promoveu, na segunda metade do século, o desenvolvimento de centros urbanos, espaços onde novas atividades econômicas possibilitaram o surgimento de novas modalidades de trabalho e, consequentemente, novas formas de sociabilização. O aumento do comércio de livros, apesar da censura, a formação de grandes bibliotecas particulares e o surgimento de espaços de discussão e, portanto, de difusão de ideias a partir de impressos - sociedades literárias e o próprio local de comércio das obras impressas -, eram sinais de um novo perfil de sociedade que se delineava a partir dos setecentos. ${ }^{50}$ Apesar de inventariadas mais de trezentas obras anteriores a 1808 , de autores nascidos na América portuguesa ${ }^{51}$, as mudanças do século XVIII não chegaram ao ponto de promover a instalação da imprensa no território do Brasil. Existem registros de poucas iniciativas isoladas que foram suprimidas pelas autoridades metropolitanas.

No início de 1706, com a permissão do governador Francisco de Castro Morais, instalou-se no Recife uma pequena tipografia para impressão de letras de câmbio e orações, que foi liquidada pela carta régia de 8 de junho do mesmo ano.

\footnotetext{
${ }^{50}$ Conforme assinalado na introdução deste trabalho, interseções entre expressões orais e escritas, e entre as práticas letradas e iletradas ampliavam este quadro para muito além da esfera alfabetizada.

${ }^{51}$ Não só livros, mas impressos relatando festejos e acontecimentos, antologias e índices, poesias, textos sobre gramática, botânica, agricultura e medicina, além de manuscritos inéditos de autores clássicos. Inventário realizado por MORAES, Rubens Borba de. Bibliografia brasileira do período colonial. São Paulo: IEB-USP, 1969. Citado por MARTINS, Ana Luiza; LUCA, Tania Regina de (org). História da Imprensa no Brasil. São Paulo: Contexto, 2008.
} 
Quarenta anos depois, também com conhecimento da administração local, Antônio Isidoro da Fonseca, antigo impressor em Lisboa, transferiu-se para colônia trazendo o material com o qual montou no Rio de Janeiro uma pequena oficina. Chegou a imprimir alguns trabalhos antes que a metrópole cuidasse da sua extinção. "Mandou a corte aboli-la e queimá-la, para não propagar ideias que podiam ser contrárias ao interesse do Estado". ${ }^{52}$ Werneck Sodré relaciona o caso a ordem régia de 6 de julho de 1747, que mencionava o conhecimento de terem vindo para o Brasil "quantidade de letras de imprimir", que mandava sequestrar para o Reino, por conta do dono, notificando-o que "não imprimissem livros, obras ou papéis algum avulsos, sem embargo de quaisquer licenças que tivessem para dita impressão, sob pena de que, fazendo o contrário, seriam remetidos presos para o Reino para se lhes impor as penas em que tivessem incorrido, de conformidade com as leis e ordens a respeito". 53 Somente em 1808 - entre as providências iniciais da Corte portuguesa transferida para América -, instituiu-se a Impressão Régia, por decreto de 13 de maio. Apesar da censura e tentativas metropolitanas de controle dos impressos que por aqui circulavam, a instauração da imprensa no Brasil não aconteceu num vazio cultural, mas em meio a uma densa trama de relações e maneiras de transmissão de ideias e informações já existentes. Neste contexto, o periodismo surgiu com papel protagonista, marcando e ordenando discursos numa cena pública que refletia as transformações em amplos setores do Império português e do mundo ocidental, em suas dimensões políticas e sociais. Assim, em 10 de setembro daquele ano saia a público o número inaugural da Gazeta do Rio de Janeiro, primeiro periódico inteiramente produzido no Brasil. ${ }^{54}$

\footnotetext{
${ }^{52}$ SODRÉ, Nelson Werneck, op. cit., p. 17.

${ }^{53}$ Citado por SODRÉ, Nelson Werneck, op. cit., p. 17-18.

${ }^{54}$ Sua publicação seguiu ininterrupta até 31 de dezembro de 1822 .
} 
Embora seu projeto inicial fosse de uma publicação semanal, o periódico passou a ser bissemanal ainda no seu primeiro mês, saindo às quartas-feiras e aos sábados. Inicialmente dirigida por frei Tibúrcio José da Rocha, quatro anos depois, por Manuel Ferreira de Araújo Guimarães, e após a mudança de orientação política promovida pelo movimento liberal português (1821), a Gazeta do Rio de Janeiro passou a ter como novo redator o cônego Vieira Goulart. ${ }^{55}$ Era uma publicação elaborada nos moldes do Antigo Regime: impressão oficial dependente de autorização prévia para veiculação de conteúdos, que funcionava como porta voz da Coroa. Segundo John Armitage, "só se informava ao público com toda a fidelidade do estado de saúde de todos os príncipes da Europa, e de quando em quando as suas páginas eram ilustradas com algum documento de ofício, notícia dos dias natalícios, odes e panegíricos a respeito da família reinante". ${ }^{56}$ Além dos ofícios, decretos, leis e anúncios de produtos e serviços disponíveis na nova sede da Corte, em suas páginas também se reproduziam extratos informativos sobre a política internacional inicialmente, preferindo notícias relacionadas aos conflitos peninsulares. De caráter predominantemente informativo, raramente veiculava artigos de opinião, o que a

\footnotetext{
${ }^{55}$ Pouco se sabe sobre o primeiro redator de periódico no Brasil. Não se conhece data de nascimento ou morte, tendo-se apenas vagas informações de sua origem portuguesa, e do cargo de oficial da Secretaria de Estado dos Negócios Estrangeiros e da Guerra, que ocupou no Brasil. Manuel Ferreira de Araújo Guimarães (1777-1838), nascido na Bahia e formado em Portugal, também foi o fundador do jornal literário e político, "O Patriota", em 1813, era engenheiro militar, professor das Academias de Marinha de Lisboa e do Rio de Janeiro e foi deputado da Assembleia Constituinte brasileira de 1823. Francisco Vieira Goulart (? - 1839), cônego, natural da Ilha Terceira, nos Açoires, segundo suas próprias palavras fora"encarregado de vários trabalhos físicos e econômicos na capitania de São Paulo em 1796. Voltou à sua terra natal e retornou ao Brasil em 1811 quando recebeu a Ordem de Cristo. "Quando rebentou o movimento constitucional no Rio de Janeiro, redigiu o periódico $O$ Bem da Ordem, aprovado por D. João VI, que mandou imprimir a custa da nação para ser enviado, como foi, às várias províncias do Brasil". Iniciou suas atividades na Gazeta do Rio de Janeiro em 4 de agosto de 1821. Além de dirigir a Imprensa Régia, foi bibliotecário da Biblioteca Nacional no Rio de Janeiro no Primeiro Reinado. SILVA, Maria Beatriz Nizza da, op. cit., p. 10-22.

${ }_{56}$ ARMITAGE, John. História do Brasil desde o periododa chegada da família de Bragança, em 1808, até a abdicação de D. Pedro I em 1831. Citado por SODRÉ, Nelson Werneck, op. cit., p. 20.
} 
limitava enquanto veículo de propagação e fomentação de discussões públicas sobre os assuntos ligados à política. ${ }^{57}$

Contudo, a simples circulação de informações promovida pela Gazeta já era bastante relevante, pois compunha uma política de Estado que, em última medida, respondia às demandas impostas pela necessidade de manutenção da integridade da monarquia portuguesa numa conjuntura a ela desfavorável. Foi um dos meios privilegiados de operar esta unidade promovendo, entre os súditos portugueses, a ideia de comunhão de interesses. Como assinalado por Garrido Pimenta, "além de disponibilizar conhecimento sobre as diversas partes do Brasil, da Europa e do mundo, e portanto, dos desafios impostos ao conjunto da nação portuguesa, a Gazeta do Rio de Janeiro propiciava aos seus leitores a materialização mesmo da nação e a face mais visível de sua unidade, que eram o Estado, a dinastia e o monarca". 58

Até a segunda década dos oitocentos, foram poucos os jornais impressos no Brasil. Depois da Gazeta do Rio de Janeiro, publicaram-se a Idade de Ouro do Brasil, de maio de 1811 a junho de 1823 , e $O$ Patriota, de janeiro de 1813 a dezembro de 1814. Também circulavam periódicos impressos no exterior, voltados aos assuntos da América portuguesa: o Correio Braziliense, $O$ Investigador Português, $O$ Contemporâneo e O Português ou Mercúrio Politico, Comercial e Literário. ${ }^{59}$ Entre estes, o Correio Braziliense foi produção de grande destaque na promoção do alargamento do horizonte da imprensa nos domínios portugueses na América.

\footnotetext{
${ }^{57}$ MOREL, Marco. La Gênesis de la Opinión Pública Moderna y el Proceso de Independência: Rio de Janeiro1820-1840. In.: GUERRA, François-Xavier; LEMPÉRIÈRE, Annick. Los espacios públicos em Iberoamerica, op. cit., p. 302; PIMENTA, João Paulo Garrido. O Brasil e a América Espanhola (18081822), op. cit., p. 41.

${ }^{58}$ PIMENTA, João Paulo Garrido. O Brasil e a América Espanhola (1808-1822), op. cit., p. 42.

${ }^{59}$ SODRÉ, Nelson Werneck, op. cit., p. 30-34.
} 
Periódico mensal editado em Londres, desde junho de 1808, por Hipólito da Costa, tributário do reformismo ilustrado, ${ }^{60}$ no primeiro número de sua publicação expõe os objetivos de sua empreitada:

"Levado destes sentimentos de Patriotismo, e desejando aclarar os meus compatriotas sobre os fatos políticos, civis e literários da Europa, empreendi este projeto, o qual espero mereça a geral aceitação daqueles a quem o dedico.

Longe de imitar só, o primeiro despertador da opinião pública nos fatos que excitam a curiosidade dos povos, quero, além disso, traçar melhorias das ciências, das artes e em uma palavra de tudo aquilo que pode ser útil à sociedade em geral". ${ }^{61}$

No tocante a última parte de sua proposta, o Correio Braziliense converteu-se em veículo pelo qual seu editor objetivava convencer as elites políticas portuguesas de que a melhor alternativa para a crise em que se encontrava estava na união de todos em torno da reforma monárquica. ${ }^{62}$

\footnotetext{
${ }^{60}$ O Correio Braziliense foi publicado sem interrupções até 1822, somando um total de 175 números. Seu editor era natural da colônia de Sacramento - povoação portuguesa na margem oriental do Rio da Prata, hoje território do Uruguai -, refugiado na capital inglesa desde 1805 sob acusação de envolvimento com a maçonaria. Sua identidade política foi fortemente influenciada por dom Rodrigo de Sousa Coutinho, o conde de Linhares - com quem desenvolveu um relacionamento conturbado -, afilhado de batismo e herdeiro político do Marquês de Pombal e seu despotismo ilustrado, além de ser a principal figura do chamado "partido inglês" na política portuguesa. Sobre Hipólito da Costa: DOURADO, Mecenas. Hipólito da Costa e o Correio Braziliense. Rio de Janeiro: Editora Biblioteca do Exército, 1957, 2 vols.; RIZZINI, Carlos. Hipólito da Costa e o Correio Braziliense. São Paulo: Companhia Editora Nacional, 1957; na coletânea COSTA, Hipólito José da. Correio Braziliense ou Armazém Literário. Vol. XXX (tomo 1). São Paulo: Imprensa Oficial do Estado, 2002: LUSTOSA, Isabel. His Royal Highness e Mr. Da Costa, p. 15-61; PAULA, Sérgio Goes de e LIMA, Patrícia Souza. Os paradoxos da liberdade, p. 111-161; COSTELLA, Antônio F.. Notas genealógicas: o ramo inglês, p. 161-167; COSTA, Fernando Hypólito da. Notas genealógicas: o ramo brasileiro, p. 269-321. ${ }^{61}$ Correio Braziliense n. ${ }^{\circ}$ 1, junho de 1808, op. cit., vol. 1, p. 4.

${ }^{62}$ JANCSÓ, István; SLEMIAN, Andréa. Um caso do patriotismo imperial. In.: COSTA, Hipólito José da. Correio Braziliense ou Armazém Literário, op. cit., vol. 30 (tomo1), p. 611.
} 
O periódico era impresso no formato de uma brochura e organizado em quatro seções principais: "Política", "Comércio e Artes", "Literatura e Ciências", e "Miscelânea". Na primeira seção, reproduzia documentos oficiais do governo português ou outros relacionados a ele - ao contrário dos periódicos oficiais como a Gazeta do Rio de Janeiro -, com o propósito de promover o fomento da discussão pública sobre assuntos políticos. ${ }^{63}$ Nas duas seções seguintes, eram reproduzidos, e ocasionalmente comentados, extratos de outros impressos, cartas, tabelas e notas. $\mathrm{Na}$ última parte, o editor do Correio Braziliense fazia suas reflexões sobre os assuntos considerados de maior relevância. O objetivo era expor e discutir criticamente os assuntos do mundo ocidental, e principalmente, os relativos à administração portuguesa, postura causadora, por diversas vezes, da censura à distribuição do periódico no Brasil. Antes mesmo de completar um ano, a 27 de março de 1809, o jornal teve a circulação proibida, os exemplares enviados ao Brasil foram apreendidos por ordem do conde de Linhares ao juiz da Alfândega, José Ribeiro Freire:

"O Príncipe Regente Nosso Senhor, a cuja Real Presença levei o ofício de V. M. justamente com o aviso e a brochura vinda de Londres, cheia de calúnias contra a nação e o governo inglês; cheia de atrozes falsidades contra várias pessoas e das maiores absurdidades sobre economia política, o qual V. M. justamente deteve. É servido ordenar que V. M. mande guardar o mesmo Aviso e obras, não o entregando a pessoa alguma e que o mesmo pratique com todas as cópias e exemplares de semelhantes obras que possam vir para o futuro, não querendo S. A. R. permitir que se divulgue nos seus Estados uma obra cheia de veneno político e falsidade e que

\footnotetext{
${ }^{63}$ DINES, Alberto. O patrono e seu modelo. In.: COSTA, Hipólito José da. Correio Braziliense ou Armazém Literário, op. cit., vol. 1, p. xxxviii.
} 
pode iludir gente superficial e ignorante, além de ser um verdadeiro libelo. É igualmente S. A. R. servido que V. M. mande mais um exemplar e Aviso para ficar nesta Secretaria de Estado, e que remeta outro ao Intendente Geral da Polícia, a quem expedem as ordens particulares sobre o procedimento que se deve tomar a este respeito". 64

As "calúnias" e as "absurdidades" citadas provinham das críticas veiculadas pelo Correio Braziliense, em outubro de 1808, às ordens estabelecidas "por vários papéis oficiais". Entre eles, o que determinava a adoção do antigo sistema de aposentadorias, que segundo Hipólito da Costa, era "um dos mais opressivos regulamentos do intolerável governo feudal", e que por isso, "não pode deixar de fazer o novo governo do Brasil odioso ao povo". Entre os vários decretos comentados, o de 11 de junho de 1808, que discriminava os portos do Brasil pelos quais se permitia a entrada e mercadorias estrangeiras. O editor iniciou seu comentário questionando "que razão se possa dar de limitar-se o comercio do Brasil a 4 portos somente, senão, o efeito do antigo prejuízo, do sistema de monopólio, que tem sempre em Portugal feito preferir o interesse de certos indivíduos ao da nação geral”. E ao concluir, avisou que em outra ocasião trataria "mais por extenso destes regulamentos", certo da "desaprovação formal de todos os homens que tem algum conhecimento de economia política, e da situação do Brasil”. ${ }^{65}$

Apesar das tentativas de censura, as páginas do periódico editado em Londres por Hipólito da Costa tornaram-se o grande expoente no campo da opinião no universo luso-americano - antes da década de 1820. A necessidade de combater e

\footnotetext{
${ }^{64}$ Citado por DOURADO, Mecenas, op. cit., vol. 1, p. 271. Segundo o autor, era o primeiro ato proibindo a circulação do Correio Braziliense na América Portuguesa.

${ }^{65}$ Correio Braziliense n. ${ }^{\circ}$ 5, outubro de 1808, op. cit., vol. 1, p. 420-425.
} 
neutralizar sua ação levou o governo português a estimular e até mesmo financiar tentativas de publicações contrárias. Já em 1809 publicaram-se as Reflexões sobre o Correio Braziliense, redigido por frei Joaquim de Santo Agostinho Brito França Galvão - impressos apenas seis números -, panfletos foram distribuídos em todo território português em ambos os lados do Atlântico, sem grande resultado e, então, em 1811, fez-se um empreendimento de maior vulto, O Investigador Português, produzido também em Londres com orientação direta do embaixador português na Inglaterra, D. Domingos de Sousa Coutinho, o conde de Funchal e irmão do conde de Linhares. Sem o mesmo fôlego editorial do Correio Braziliense, O Investigador Português encerrou suas atividades em fevereiro de $1819 .{ }^{66}$

As análises de Hipólito da Costa não se restringiam às possessões portuguesas; como já dito, versavam também sobre os acontecimentos de outras partes do mundo, em especial da Espanha e seus domínios na América . Os acontecimentos vizinhos poderiam ser utilizados como exemplos na tentativa de prevenir a Corte lusitana sobre os perigos de uma administração equivocada.

Mesmo antes das convulsões em território americano - explicadas e até justificadas, segundo Hipólito da Costa, pela má conduta do governo da Espanha -, a corrupção da administração espanhola e a urgência de reformas para corrigi-la já eram apontadas nas páginas do Correio Braziliense. Em fevereiro de 1810, publicou:

"E na verdade se o sistema de Governo estava tão corrompido, como todos se vêem obrigados a confessar, que outro meio se podia conceber, para regenerar a Nação senão a convocação de Cortes, que são as únicas que podem ter essa influência e autoridade para fazer reformas da magnitude que são necessárias?

\footnotetext{
${ }^{66}$ SODRÉ, Nelson Werneck, op. cit., p. 30-32; MECENAS, Dourado, op. cit., p. 318-322.
} 
Na nossa opinião, que julgamos ser também a de todos os homens imparciais, ou as Cortes de Espanha hão de proceder seriamente a essa reforma; ou Napoleão há de modelar aquele país como lhe convier". ${ }^{67}$

Da mesma forma, as críticas contundentes ao governo português veiculadas pelo Correio Braziliense, tinham objetivo reformador. Pregava a mudança no sentido de melhorar a administração portuguesa principalmente no tocante à sua colônia na América, como exemplifica este trecho de julho de 1810 sobre o gerenciamento das finanças do Brasil:

“(...) não há repartição em Portugal onde se possam cometer abusos mais prejudiciais à Nação do que na repartição do Erário. Há dois anos e meio que se transplantou para o Brasil a Corte, e até agora as finanças daquele pais não tem de forma alguma melhorado; (...)" Um dos maiores defeitos da administração internas das colônias portuguesas, foi sempre a falta de responsabilidade eficaz, nas pessoas que exercitam a autoridade, e isto procede não de que as leis, em teoria, não os façam responsáveis; mas pela distancia das colônias à metrópole; por não haver liberdade de imprensa, que publique os abusos dos que governam; pela falta de assembleias ou conselhos coloniais independentes da Coroa, que sirvam de contrabalançar o poder dos governadores". 68

\footnotetext{
${ }^{67}$ Correio Braziliense n. ${ }^{\circ}$ 21, fevereiro de 1810, op. cit., vol. 4, p. 208.

${ }^{68}$ Correio Braziliense n. ${ }^{\circ}$ 26, julho de 1810, op. cit., vol. 5, p. 120.
} 
Dessa maneira Hipólito da Costa preocupava-se em prevenir o governo português sobre as possíveis consequências desastrosas de uma administração ruim. Os acontecimentos da vizinhança hispânica serviriam como exemplo do indesejável. Em agosto de 1810, após tantas críticas aos equívocos do governo metropolitano, o editor do Correio Braziliense não se mostrou surpreso com os acontecimentos na América Espanhola:

"Havíamos anunciado no nosso numero passado a revolução de Caracas, e neste noticiamos a do Rio-da-Prata, executada justamente no mesmo sentido; e seguindo naturalmente os mesmos passos. (...). Nós demos a entender, por várias vezes no nosso periódico, que sabíamos da tendência progressiva do espírito de independência na América; (...)”. ${ }^{69}$

Em sentido contrário, a Gazeta do Rio de Janeiro abstinha-se de noticiar os acontecimentos da turbulenta vizinhança hispânica - aparentemente buscando poupar os domínios portugueses de exemplos, cujas consequências, no Brasil, eram ainda imprevisíveis. $^{70}$

Contudo, a aparente contraposição entre o Correio Braziliense, publicação crítica em relação ao governo português, e a Gazeta do Rio de Janeiro, veículo oficial desse governo, não pode ser tomada como absoluta. Esses periódicos compartilhavam a defesa do governo monárquico, da dinastia de Bragança e do projeto de união entre

\footnotetext{
${ }^{69}$ Correio Braziliense n. ${ }^{\circ}$ 27, agosto de 1810, op. cit., vol. 5, p. 238-239. No capítulo 3 tratamos detalhadamente da postura do Correio Braziliense em relação à América espanhola convulsionada.

${ }^{70}$ PIMENTA, João Paulo Garrido. Estado e nação no fim dos Impérios ibéricos no Prata (1808-1828). São Paulo: Hucitec, 2002, p. 103-105.
} 
as partes do Império português para sua manutenção. ${ }^{71}$ A principal diferença entre eles consistia na forma de defesa desses propósitos. Ao Correio Braziliense, por exemplo, era essencial o conhecimento sobre o que se passava na parte espanhola da América e, para isso, acompanhava atentamente a circulação de periódicos sobre o assunto, tanto os europeus quanto os hispano-americanos. Como prova o debate travado com o Correo del Orinoco entre 1817-1820.

Assim, além de informar a América portuguesa em relação aos principais acontecimentos do mundo ocidental, o periódico editado por Hipólito da Costa também levava as discussões sobre os assuntos do Império português para além de suas fronteiras - circulando, seguramente, por muitas regiões da América e da Europa. O Correio Braziliense era o grande responsável pela inserção do mundo lusoamericano num espaço público de discussão mais amplo, que transpunha os limites dos Estados existentes, contribuindo, assim, para que processos históricos distintos convergissem e se influenciassem. É precisamente o que se vislumbrou a partir de seu debate com o Correo del Orinoco, entre 1817 e 1820.

\footnotetext{
${ }^{71}$ Marco MOREL; Mariana Monteiro de BARROS. Palavra, imagem e poder, op. cit., p. 19.
} 


\section{CAPÍTULO 2: A CRISE POLÍTICA DOS IMPÉRIOS IBÉRICOS}

2.1- Investidas napoleônicas: os primeiros impactos na América ibérica (1808-1809)

De forma bastante preliminar, podemos afirmar terem as investidas napoleônicas na península ibérica, no final do ano de 1807 e início de 1808, desencadeado processos cujos desdobramentos não imediatos resultaram na independência política das colônias de Espanha e Portugal na América. As soluções imediatas adotadas pelas duas metrópoles - Portugal e Espanha - e as reações provocadas em suas respectivas possessões americanas foram bastante distintas, mas, assim como o princípio, o final dos processos evidencia a unidade da conjuntura em que estão inseridos.

No caso português, o translado forçado da Corte para os trópicos provocou a transferência do centro do Império de Lisboa para o Rio de Janeiro, garantindo imediatamente a integridade da representação dinástica, além de promover expectativas positivas entre as elites das diversas partes do Brasil, que, mais próximas do centro do poder, podiam almejar a ampliação de sua participação nos assuntos da gerência pública. $^{72}$

A situação espanhola, num primeiro momento, pode parecer oposta. O monarca espanhol e seu herdeiro foram obrigados a renunciar ao trono em favor de José Bonaparte, irmão de Napoleão, estabelecendo a difícil questão da legitimidade do poder na ausência do soberano, tanto para península quanto para a America. ${ }^{73} \mathrm{Na}$

\footnotetext{
72 JANCSÓ, István; PIMENTA, João Paulo Garrido. Peças de um mosaico (ou apontamentos para o estudo da emergência da identidade nacional brasileira). In.: MOTA, Carlos Guilherme (org.). Viagem Incompleta. A experiência brasileira 1500-2000. São Paulo: SENAC, 2000, p. 153.

${ }^{73}$ Antes do apogeu da crise, a Espanha assinou com a França o Tratado de Fontainebleau, em 27 de outubro de 1807, pelo qual os dois países acordaram a conquista e partilha de Portugal. As tropas franco-espanholas, comandadas por Junot, ocuparam Portugal, mas contrariando as cláusulas do
} 
ausência do rei, cessavam também todas as autoridades delegadas, e havia que constituir uma solução governativa que exercesse a soberania reassumida pelo povo. ${ }^{74}$

A partir da confirmação das renúncias, em maio de 1808, a população espanhola se levantou contra a ocupação francesa. Pouco tempo depois, também na América, multiplicaram-se as demonstrações de fidelidade à dinastia bourbônica, e até mesmo, em alguns casos, o envio de recursos para guerra em território metropolitano. $^{75}$

$\mathrm{Na}$ busca da manutenção da ordem golpeada, estabeleceram-se Juntas Provinciais de Governo. Algumas delas, em razão da importância da cidade onde se constituíram, transformaram-se em centros de poderes territoriais ao submeterem autoridades locais de toda uma região. Oviedo, Valladolid, Badajoz, Sevilha, Valência, Lérida e Zaragoza foram os centros onde se constituíram “Juntas Supremas Provinciais". Um mês após a renúncia forçada do monarca, “a península se encontra governada de acordo com o seguinte esquema: dois capitães gerais e treze Juntas Supremas de origem popular e caráter colegiado, das quais dependem um número indeterminado de Juntas, locais ou especializadas, como a de armamentos que se criaram em alguns pontos". ${ }^{76}$

A necessidade de conservação da unidade nacional e de concentração dos esforços de guerra contra os franceses levaram as Juntas Provinciais, através de medidas não coordenadas porém convergentes, à formação de um governo central.

tratado, Napoleão não só se apoderou de todo país como investiu contra a própria Espanha. Utilizando a situação, a oposição ao governo de Carlos IV conseguiu sua abdicação em favor de Fernando, seu herdeiro - motim de Aranjuez, em 17 de março de 1808. As tropas francesas comandadas por Murat ocuparam Madri. Napoleão convocou Carlos IV e seu herdeiro à Baiona, onde conseguiu a abdicação de ambos em seu favor - no dia 6 de maio daquele ano -, e nomeou seu irmão José Bonaparte para o governo de Espanha.

${ }^{74}$ GUERRA, François-Xavier. Modernidad e Independências, op. cit., p. 127; ARTOLA, Miguel. La burguesía Revolucionaria (1808-1874), 5 ed., Madri: Alianza Editorial, 1977, p. 9-15.

${ }^{75}$ PARRA-PEREZ, Caracciolo. Historia de la primera Republica de Venezuela. Caracas: Biblioteca Nacional de História, 1959, volume 1, p. 319.

${ }^{76}$ ARTOLA, Miguel. Antiguo Régimen y Revolución liberal, op. cit, p.161 et seq. 
Apesar da unanimidade quanto à necessidade de centralização do governo, foi difícil harmonizar as pluralidade de posições quanto sua composição e atribuições. Finalmente, em pouco mais de três meses, estabeleceu-se em Sevilha - capital da Andaluzia - a Junta Central de Governo. ${ }^{77}$

Porém, "por mais que se decidisse considerá-la envolta com o manto da legitimidade, não podia ser equiparada a uma sucessão dinástica". ${ }^{78}$ A aceitação do poder desta Junta supunha o reconhecimento de sua representatividade, diferente da legitimidade real, que era inquestionável. A partir de então, a relação entre o governo metropolitano e a administração colonial seria gradativamente redefinida.

$\mathrm{Na}$ América, as demonstrações de fidelidade ao rei não significavam exatamente fidelidade à nova ordem estabelecida na metrópole, pelo menos não para alguns setores das sociedades hispano-americanas. Na Cidade do México, em setembro de 1808, anunciou-se a criação de uma instância local que governasse em nome do rei cativo. ${ }^{79}$ No mesmo mês, formou-se a junta de governo de Montevidéu. ${ }^{80}$

Não demorou muito para um seleto grupo da província de Caracas se manifestar na mesma direção. Em 24 de novembro de 1808 entregou-se ao Capitão Geral e Governador da Província, dom Juan de Casas, uma representação com quarenta e cinco assinaturas cujo objetivo final era declarar o estabelecimento de uma “junta em pleno e livre exercício de autoridade, que se deva exercer em nome e representação" do "augusto soberano, o senhor dom Fernando VII" ${ }^{81}$ Este movimento ficou conhecido como a conjura dos mantuanos. ${ }^{82}$ Tal petição tinha como

\footnotetext{
${ }^{77}$ Para o processo de formação das Juntas: ARTOLA, Miguel. Antiguo Régimen y Revolución liberal, op. cit., p. 159-174; Idem. La burguesia revolucionaria (1808-1874), op. cit., p. 7-37.

${ }^{78}$ HALPERIN DONGHI, T.. Reforma y disolución de los imperios ibéricos 1750-1850, op. cit., p. 116.

${ }^{79}$ Ibdem, p. 117.

${ }^{80}$ Ver PARRA-PEREZ, Caracciolo, op. cit., p. 344 e PIMENTA, e João Paulo Garrido. O Brasil e a América Espanhola (1808-1822), op. cit., p. 64.

${ }^{81}$ PARRA-PEREZ, Caracciolo, op. cit, p. 334.

${ }^{82}$ Como já assinalado, os mantuanos eram um grupo socialmente distinto entre os criollos. Inés Quintero usa a demoninação principales ao se referir a eles. Sobre nobreza criolla da Venezuela:
} 
principal argumento a igualdade de direitos entre os súditos dos dois lados do Atlântico, e propunha, para a Venezuela, uma solução correspondente à peninsular:

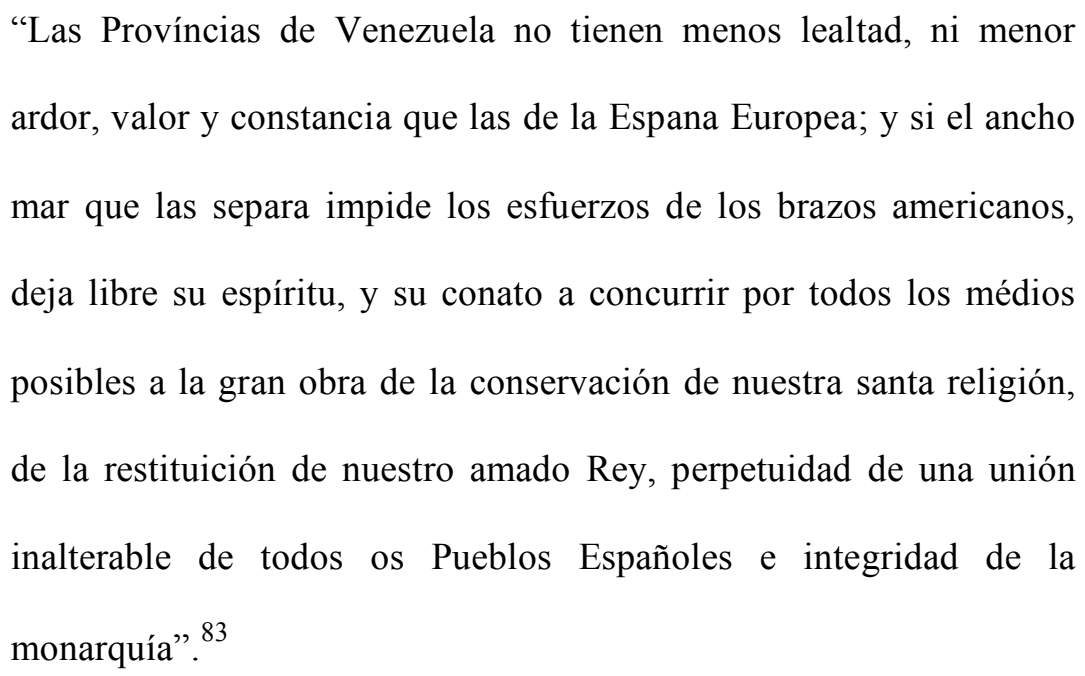

Embora a fidelidade ao monarca fosse reiterada, e os argumentos se fundamentassem em valores típicos do Antigo Regime - defesa da Religião, da Monarquia e do Rei -, efetivamente, buscava-se um governo em opção ao metropolitano, cujo futuro dependia do curso incerto da guerra. Alguns historiadores afirmam, equivocadamente, que sob estas demonstrações de fidelidade ao monarca e de preocupação com o bem público, os caraquenhos ocultavam o deliberado propósito de separar-se da metrópole. Segundo Parra-Perez, os eventos posteriores dão a estas hipóteses aparente fundamento, mas seria aventureiro tê-las como indiscutíveis, pois estes mesmos eventos demonstram que os mantuanos careciam de planos definidos. ${ }^{84}$ Neste sentido, Inês Quintero adota como mais precisa a interpretação do historiador Elias Pino Iturrieta, por considerar que os “desajustes políticos da metrópole

QUINTERO, Inés. La conjura de los mantuanos. Caracas: Universidad Católica Andrés Bello, 2002; Idem. Los Nobles de Caracas. Caracas: Academia Nacional de História, 2005. In.: www.anhistoriavenezuela.org/pdf/discursos/dis34.pdf

${ }^{83}$ Documento transcrito por QUINTERO, Inés. La conjura de los mantuanos, op. cit., p. 106.

${ }^{84}$ PARRA-PEREZ, Caracciolo. Historia de la primera Republica de Venezuela, op. cit., p. 334. 
constituíram a conjuntura apropriada para que este setor da sociedade colocasse em marcha as suas aspirações de poder, seus desejos de obter um maior controle da província." ${ }^{85} \mathrm{Na}$ visão destes autores, a consequência fundamental desta conjura, foi uma maior ruptura entre os mantuanos e as autoridades espanholas - que aos poucos, os substituíam na preferência, concedendo prerrogativas aos pardos. ${ }^{86}$ Assim tal movimento, embora não tivesse aspirações de independência, estabeleceu uma situação determinante para o desenlace dos acontecimentos posteriores naquela província.

Movimentos análogos se sucederam em outros territórios das possessões espanholas em ultramar num sincronismo determinado principalmente pelo exemplo peninsular: o estabelecimento de juntas autônomas governativas em nome do rei cativo. No ano de 1809, foram constituídas as juntas de Chuquisaca (no Alto Peru, em 25 de maio), La Paz (16 de julho), Quito (no vice-Reino de Nova Granada, em 10 de agosto) e iniciativas foram sufocadas em Buenos Aires. ${ }^{87}$

Estas ações no sentido de exercício do poder político desvinculado da metrópole não podem ser caracterizadas como o princípio de movimentos pela independência política destes territórios, tampouco como escaramuças entre elites americanas e espanholas. A análise de tais iniciativas deve considerar a perspectiva de grupos locais, compostos tanto por criollos como por peninsulares fixados nos

\footnotetext{
${ }^{85}$ QUINTERO, Inés. La conjura de los mantuanos, op. cit., p. 14 (tradução livre).

${ }^{86}$ Ver PINO ITURRIETA, Elias. Mantuanos e Independência. In.: Gran enciclopédia de Venezuela. Caracas: Editorial Globe, tomo 3, 1998, p. 251. Citado por QUINTERO, Inês, op. cit, p. 14. O termo "pardo" era utilizado para designar qualquer tipo de mestiço. A população parda era bastante heterogênea, com distinções internas definidas por características econômicas, sociais, pelo ganho da atividade desenvolvida e por sua ascendência - aqueles que não tinham nenhum traço étnico negro eram positivamente distinguidos. Os pardos não podiam ocupar cargos públicos, militares ou eclesiásticos. A partir da instituição, por Carlos IV, da real cédula de "Gracias al Sacar", em 10 fevereiro de 1795, tornou-se possível a compra de privilégios que antes eram exclusivos dos brancos. Vide SALCEDO-BASTARDO, José Luis. Historia fundamental de Venezuela. $11^{\mathrm{a}}$ ed., Caracas: Universidad Central de Venezuela, Ediciones de la Biblioteca, 2006, p. 98-103.

${ }^{87}$ PARRA-PEREZ, Caracciolo. Historia de la primera Republica de Venezuela, op. cit., p. 345-346 e PIMENTA, João Paulo Garrido. O Brasil e a América Espanhola (1808-1822), op. cit., p. 64-65.
} 
trópicos - como os espanhóis Francisco de la Cámara, Antonio e Sebastián Férnandez de Léon, participantes da conjura mantuana -, ávidos por ampliar o poder de decisão em suas respectivas províncias, mas também a necessidade de uma resposta urgente à crise peninsular para garantir a ordem interna nos territórios americanos, o que somente seria possível em nome do legítimo detentor do poder, o rei. "A conduta dos notáveis de Caracas era exatamente a mesma que as dos capitulares de Nova Espanha (...) e dos patrícios de Quito. Nos discursos de todos eles está presente o mesmo propósito de lealdade, a mesma preocupação em evitar o desmantelamento da unidade espanhola e o interesse em atender a emergência que agitava a vida política da península". ${ }^{88}$ Contudo, para o poder metropolitano, sobreavisado pela experiência das colônias norte-americanas - há pouco independentes -, tais manifestações foram consideradas traições e, por isso, foram reprimidas.

Ainda em 1809, a Junta Central de Sevilha declarou igualdade entre todas as províncias da monarquia espanhola, inclusive as americanas, e convocou seus representantes para formação do governo e discussão sobre as reformas que a conjuntura exigia. ${ }^{89}$ As eleições dos representantes americanos para a Junta central peninsular provocou ampla mobilização em toda a América Espanhola. Dentre as complexas e oscilantes implicações na nova maneira de relacionamento entre a península e a América, inaugurada com privação da figura do rei, a escolha de deputados americanos para o governo central espanhol é um fato sem precedentes na história e foi fundamental para a definição de iniciativas de rompimento com o poder metropolitano iniciadas no ano seguinte. Embora o processo eleitoral não tivesse sido concluído em todo território americano e, os poucos deputados eleitos não chegaram a

\footnotetext{
${ }^{88}$ QUINTERO, Inés. La conjura de los mantuanos, op. cit., p. 116.

${ }^{89}$ A Junta Central ainda convocou as Cortes em Cádiz - uma assembleia constituinte - para submeter o projeto de elaboração de uma Constituição para toda a nação espanhola. Vide ARTOLA, Miguel. Antiguo Régimen y Revolución liberal, op. cit., p. 159-174.
} 
tomar assento nas Cortes - devido dissolução da Junta Central no início de 1810 -, o desenvolvimento destas eleições evidenciaram o distanciamento de interesses entre os pilares da monarquia espanhola, revelaram atores da vida política americana e neles alimentaram um novo imaginário sobre as políticas em seus respectivos territórios. ${ }^{90}$

Assim, as redefinições impostas às monarquias ibéricas pela política francesa na Europa alimentaram em determinados grupos de suas respectivas possessões americanas o mesmo anseio pela ampliação de espaços de poder.

Na América portuguesa, com o translado da família real para o Brasil, as linhas gerais da política e econômica do Império lusitano passaram a ser definidas a partir do novo eixo organizador estabelecido no Rio de Janeiro. ${ }^{11}$ Em sentido contrário ao dos seus vizinhos hispânicos, que sem o soberano buscaram alternativas ao governo metropolitano, os luso-americanos criaram expectativas positivas em relação à proximidade com o seu rei.

Uma das primeiras medidas tomadas pelo governo português em território americano foi a abertura dos portos do Brasil ao comércio com navios estrangeiros, por meio da Carta Régia de 28 de janeiro de 1808, e consequentemente o que implicaria o fim do exclusivo metropolitano. Uma outra medida, de abril do mesmo

\footnotetext{
${ }^{90}$ Sobre as eleições na América espanhola e suas implicações: François-Xavier GUERRA. Modernidad e independencias, op. cit., p. 177-225; RODRÍGUEZ, Jaime E.. La independência de la América española. México: Fondo de Cultura Econômica, 2006, p. 82-88. Um resumo sobre o processo na Venezuela foi feito por QUINTEIRO, Inês. Soberania, representación e independência en Caracas, 1808-1811. In.: Procesos. Revista Ecuatoriana de Historia, n. ${ }^{\circ 29}, 1^{\circ}$ semestre/2009, p. 5-20.

${ }^{91}$ Sobre a transferência da Corte para América: PRADO JR., Caio. Evolução política do Brasil: colônia e império. 20a ed., São Paulo: Brasiliense 1989; HOLANDA, Sérgio Buarque de. A herança colonial - sua desagregação. In.: Idem (dir.). História geral da civilização brasileira, Tomo II , $1^{\circ}$ vol. São Paulo: Difusão Europeia do Livro, 1970, p. 09-39; DIAS, Maria Odila da Silva. A interiorização da Metrópole 1808-1853. In.: MOTA, Carlos Guilherme (org.). 1822: Dimensões. São Paulo: Perspectiva, 1972, p.160-184; NOVAIS, Fernando A.. Portugal e Brasil na crise do antigo sistema colonial (1777-1808), op. cit.; ALEXANDRE, Valentim. Os sentidos do Império. Questão Nacional e Questão colonial na Crise do Antigo Regime Português. São Paulo: Edições Afrontamento, 1993; JANCSÓ, István; PIMENTA, João Paulo Garrido. Peças de um mosaico (ou apontamentos para o estudo da emergência da identidade nacional brasileira), op. cit.; SLEMIAN, Andréa. Vida política em tempo de crise: Rio de Janeiro (1808-1824). São Paulo: Hucitec, 2006, p. 11-91.
} 
ano, golpeou definitivamente o pacto colonial ao definir o fim das proibições de atividades industriais nos domínios ultramarinos. ${ }^{92}$

Como já citado, a inauguração da imprensa com a publicação da Gazeta do Rio de Janeiro, também está entre os atos inaugurais da administração portuguesa em sua nova sede. Mas foi o Correio Braziliense que, desde seus primeiros números, mostrou-se atento aos desdobramentos do conflito em território europeu especialmente a situação peninsular - na América. A delicada questão da legitimidade de governo dos domínios espanhóis na ausência do monarca Fernando VII, é colocada em pauta logo na sua edição inaugural:

"Estes acontecimentos em Espanha são sem dúvida, intimamente ligados com os do Império do Brasil, por mais de um motivo; porque não só mostram que a Corte de Portugal não podia ter outra alternativa senão a mudança para o Brasil; pois nenhuns sacrifícios que o Príncipe Regente fizesse, poderiam obter lhe da França nem já as aparências de Soberania, que ainda então gozava o rei de Espanha (...), mas, além disso, devolvem à família de Bragança o direito do trono de Espanha; e por consequência, um justo título de se apossar daquela parte das colônias espanholas, que ficarem ao alcance de suas forças.

Como quer que seja o governo do Brasil não pode olhar para Espanha em outro ponto de vista, senão como um país que o inimigo está de posse; e as medidas, que há que tomar, devem todas estribarse neste princípio, que o Governo atual de Espanha, e o Corpo da antiga Monarquia Espanhola, são já duas entidades inteiramente diferentes. (...)

\footnotetext{
${ }^{92}$ ALEXANDRE, Valentim. Os sentidos do Império, op. cit., p. 209 et seq.
} 
Nestes termos não hesito em declarar a minha opinião de que, o Príncipe Regente do Brasil, que, por parte de sua mulher, é o único herdeiro legítimo da Monarquia Espanhola, deve apossar-se de todo o que lhe ficar ao capto; antes que o inimigo comum tome medidas convenientes, para se afirmar por tal maneira, no trono de Espanha, que até as colônias não lhe escapem". ${ }^{93}$

A ideia de estender a influência do governo português na América hispânica em torno da alegação dos direitos da princesa Carlota Joaquina (esposa de dom João, filha de Carlos IV, portanto irmã de Fernando VII), não era, evidentemente, uma sugestão de Hipólito da Costa. O projeto carlotista foi acalentado pela administração portuguesa desde os primeiros meses de 1808 e apresentado a grande parte dos domínios espanhóis na América, com repercussões variadas, que não podem ser resumidas pelos termos de adesão ou recusa, pois que implicaria no equívoco de conferir a estes territórios um quadro político homogêneo. ${ }^{94}$

Com o Manifesto de Sua Alteza Real Dona Carlota Joaquina Infanta de Espana, Princesa de Portugal e do Brazil dirigido aos vassalos espanhóis, D. Carlota Joaquina declarou-se "suficientemente autorizada a exercer as vezes" de seu Augusto pai “como a sua mais próxima representante, neste continente da América, para com seus fiéis e amados vassalos". 95 Pela Justa Reclamação, que os representantes da Casa Real de Hespanha, D. Carlota Joaquina de Bourbon Princesa de Portugal e do Brazil; e D. Pedro Carlos de Bourbon e Bragança, Infante de Hespanha fazem a S. A.

\footnotetext{
${ }^{93}$ Correio Braziliense n. ${ }^{\circ}$ 1, junho de 1808, vol. 1, op. cit., p. 61-63.

${ }^{94}$ Sobre o carlotismo: PIMENTA, João Paulo Garrido. O Brasil e a América Espanhola (1808-1822), op. cit., p. 53-64; Idem. Estado e nação no fim dos Impérios Ibéricos no Prata (1808-1828). São Paulo: HUCITEC, 2002, p. 71-102; PEREIRA, Sara Marques. D. Carlota Joaquina e os "espelhos de Clio": actuação política e figurações historiográficas. Lisboa, Horizonte, 1999.

95 Publicado pelo Correio Braziliense n. ${ }^{0}$ 7, dezembro de 1808, op. cit., vol. 1, p. 550-553. O documento também foi reproduzido pela Gazeta de Caracas, de 2 de novembro de 1810. In Gaceta de Caracas, op. cit., volume 2.
} 
R. o Príncipe Regente de Portugal, os herdeiros espanhóis solicitam o apoio de D. João - e, em decorrência da aliada Grã-Bretanha - no combate à extrapolação dos intentos napoleônicos em território americano e na manutenção de seus direitos dinásticos neste mesmo território:

"Cheios de horror com tais atentados; julgamos próprio do nosso dever implorar o auxílio de V.A.R. como amparo, e protetor natural imediato; pedindo-lhe socorros, contra a propagação deste sistema usurpador, que absorve os Estados da Europa uns depois dos outros, empenhando a V.A.R. a favor de nossa causa; para que, com o seu poder e respeito, nos ponha em estado (como os mais imediatos parentes do Rei da Espanha) de poder conservar os seus direitos, e assegurar com eles os nossos, combinando as forças portuguesas, espanholas e inglesas, para impedir os franceses, que com seus exércitos pratiquem na América as mesmas violências e subversões que já cometeram sobre quase toda a extensão da Europa". ${ }^{96}$

D. João, por sua vez, responde positivamente ao pedido, num documento assinado na mesma data - 19 de agosto de 1808 -, comprometendo-se em empenharse contra o inimigo comum de Portugal e Espanha.

Era esperado do conflito entre as nações europeias, opondo até 1808 Portugal à França e Espanha, ${ }^{97}$ ter seus desdobramentos nas respectivas possessões americanas, provocando o ressurgimento e ampliação de disputas fronteiriças na região do Prata,

\footnotetext{
${ }^{96}$ Publicado pelo Correio Braziliense, n. ${ }^{0}$ 7, dezembro de 1808, vol. 1, op. cit., p. 545.

${ }^{97}$ Considerando a situação inicial de 1808 , quando a monarquia portuguesa foi obrigada à transferir-se para os trópicos, aceitando o auxílio britânico, para escapar das tropas francesas, que com o apoio espanhol, já alcançavam a fronteira lusitana em Alcântara. Sobre acordos entre estas nações ver HALPERIN DONGHI, Tulio. Reforma y disolución de los imperios ibéricos 1750-1850, op. cit., p. 7580.
} 
ao sul, e com a Guiana, ao norte do Brasil. A Corte portuguesa necessitava de uma política externa que lhe resguardasse da expansão dos vetores revolucionários em sua nova sede, em terras americanas. Também a ausência do soberano espanhol, fonte da legitimidade da unidade monárquica, ameaçava a coesão das possessões espanholas e abria espaços para o vislumbre de novas alternativas. "É assim que, em estreita ligação com as contingências francesas, vão sendo introduzidas no mundo lusoamericano também contingências espanholas - e, portanto, hispano-americanas -, numa situação que teria no Rio da Prata o seu principal espaço de definição," ${ }^{98}$ por se tratar de importante entreposto comercial sul-americano .

Logo após a chegada da Corte no Rio de Janeiro, numa primeira investida na região, em março de 1808, o governo português, por iniciativa de dom Rodrigo de Sousa Coutinho, encaminha a Liniers, vice-rei do Rio da Prata, uma carta sugerindo a aceitação da proteção portuguesa, em virtude do subjugo da metrópole espanhola pelas forças francesas. Em contrapartida, prometia a manutenção dos impostos estabelecidos e dos privilégios existentes. A alternativa era a ameaça de um confronto armado contra as forças luso-britânicas. A resposta de Buenos Aires foi negativa, e as hostilidades contornadas pela tentativa de um acordo comercial. Contra a vontade do conselho Municipal, Liniers enviou um representante para negociações no Rio de Janeiro. $^{99}$

Os planos de estender a influência do governo português na região foram levados adiante com a articulação do projeto carlotista, uma proposta com certo grau de legitimidade dinástica, que poderia atender algum interesse separatista incipiente. A dificuldade do governo português em realizar uma intervenção eficaz na região do

\footnotetext{
${ }^{98}$ PIMENTA, João Paulo Garrido. O Brasil e a Amzérica Espanhola (1808-1822), op. cit., p. 34.

${ }^{99}$ ALEXANDRE, Valentim. Os sentidos do Império, op. cit., p. 244.
} 
Prata teria afastado progressivamente muitos partidários deste projeto. $^{100}$ Independente dos motivos de seu fracasso, o projeto carlotista, apoiado pela GrãBretanha - que interessada em sua expansão comercial marítima encontraria na América ibérica a possibilidade de um mercado especialmente vantajoso para o investimento em empréstimos a juros -, representou uma alternativa planejada pelo governo português diante das incertezas e temores em relação ao futuro da Corte Bragantina na América, mas também era a expressão de suas pretensões expansionistas, que encontravam terreno fértil para novas iniciativas.

Ao norte, uma vez declarada a guerra à França, o governo português já preparara ataque aos domínios franceses na América. Contudo, a preocupação com a defesa dos limites luso-americanos em relação a vizinhança francesa exigiu breves esforços. Em novembro de 1808, partiram do Pará as tropas portuguesas sob o comando do tenente-coronel Manoel Marques. Após rápidos conflitos, em janeiro do ano seguinte, o governo francês rendeu-se cedendo a ilha de Caiena às forças portuguesas. ${ }^{101}$

Não somente pelo resguardo de suas fronteiras, a tomada de Caiena fora conveniente para a Corte Bragantina. As mudas de plantas exóticas e especiarias, com alto valor no mercado internacional, vindas daquele território, antes em remessas clandestinas, a partir de 1809 ficaram à disposição dos portugueses. A cana caiena, a noz-moscada, o cravo-da-índia, a fruta-pão e a fruta-do-conde foram introduzidas no Brasil através de Caiena. Também de lá já tinham vindo as primeiras mudas de café ainda no século XVIII. Ao total, foram enviadas 82 espécies acompanhadas das instruções para o cultivo. Com a criação do Real Horto (1808), no Rio de Janeiro, e

\footnotetext{
${ }^{100}$ Ibdem, p. 247.

${ }^{101}$ Em 1814, após o tratado de paz de Paris, este território foi devolvido à França. LIMA, Oliveira. Dom João VI no Brasil 1808-1821. $3^{\mathrm{a}}$ ed., Rio de Janeiro: Topbooks, 1996, p. 285-300.
} 
do Horto de Olinda (1811), consolidou-se a rota de remessas de espécies vegetais de Caiena para o Pará, e de lá para o restante do Brasil. ${ }^{102}$

Parece-nos evidente que a indefinição da situação das possessões espanholas na América constituía um espaço que exigia maiores esforços da monarquia portuguesa, no sentido de medidas cautelares para manutenção de sua integridade na nova sede; ao mesmo tempo, criava condições para iniciativas expansionistas.

As relações entre a América portuguesa e a América hispânica seriam rapidamente reconfiguradas a partir das novas condições políticas consequentes do agravamento da crise dos Impérios ibéricos. A inauguração dos processos de rompimento com o poder metropolitano pela América espanhola - cujos resultados seriam as independências -, foram motivos de temores ainda maiores à administração lusitana, cada vez mais atenta aos acontecimentos na turbulenta vizinhança.

Foi a partir do território da Venezuela que os primeiros sinais da ruptura da América com o governo espanhol se fizeram evidentes, principalmente ao governo português. Como exemplifica o texto de Pedro de Sousa Holstein, futuro conde de Palmela - representante português junto à dissolvida Junta de Sevilha - ao relatar a situação na América a Dom Rodrigo de Sousa Coutinho, ministro português: “A província de Caracas foi a primeira a dar o exemplo", e tal movimento teria "um aspecto mais temível, e mais obstinado, que [de] todas as outras". ${ }^{103}$

2.2- A contestação do poder metropolitano pela América espanhola e sua repercussão no Brasil (1810-1813)

\footnotetext{
${ }^{102}$ SOARES, Ana Carolina Eiras Coelho; DUARTE, Elaine Cristina Ferreira. O Arquivo Nacional e a História Luso-Brasileira: Caiena. In.:

http://www.historiacolonial.arquivonacional.gov.br/cgi/cgilua.exe/sys/start.htm?infoid=307\&sid=47\&t $\mathrm{pl}=$ printerview

${ }^{103}$ Ofício nº ${ }^{\circ}$ 11, Cádiz, 23 de setembro de 1810. Documentos Avulsos, Legação em Cádiz. Citado por PIMENTA, João Paulo Garrido. O Brasil e a América Espanhola (1808-1822), op. cit., p. 84.
} 
Em janeiro de 1810 a invasão francesa da província da Andaluzia provocou a dissolução da Junta Central de Governo - em seguida substituída por um Conselho de Regência em Cádiz -, abrindo nova crise de sucessão. Apesar de representante frágil do monarca cativo, e debilmente reconhecida como esfera portadora de legitimidade dinástica, sua extinção promoveu o adensamento de concepções que foram convertidas em projetos antes inexequíveis. A reação da América se deu num conjunto de movimentos desprovidos de articulação direta cuja simultaneidade e semelhança constituíram notáveis sintomas do caráter estrutural da crise dos impérios ibéricos. ${ }^{104}$ Em várias cidades, inclusive em capitais administrativas - Caracas, Buenos Aires, Santa Fé de Bogotá, Santiago do Chile e Quito -, os Conselhos Municipais constituíam suas próprias juntas governativas rompendo claramente com a administração metropolitana.

Os desdobramentos deste processo na Venezuela, assim como os demais hispano-americanos, se deram em respostas imediatas às aceleradas mudanças na Metrópole. Os acontecimentos em território europeu aumentavam o clima de instabilidade em toda América espanhola, e a ansiedade por notícias ampliava os espaços para boatos e agitações - fazendo dos periódicos ferramentas mais importantes que nunca. Em Caracas, a situação chegou ao ponto do então Capitão Geral da Província, don Vicente Emparan, publicar em 7 de abril de 1810 uma declaração atribuindo a falta de notícias metropolitanas às condições meteorológicas desfavoráveis para navegação, garantindo na Espanha tudo correr bem. Uma semana depois, chegava em Puerto Cabello - na província de Caracas -, uma embarcação vinda de Sevilha trazendo as inquietantes notícias. As autoridades provinciais se

${ }^{104}$ Ibdem, p.73-74. 
viram obrigadas a colocar soldados nas ruas de Caracas recomendando tranquilidade geral, pois circulavam rumores alarmantes de uma conspiração estar prestes a se concretizar diante da perda do poder central. A grande massa da população, por sua vez, sem a dimensão precisa dos acontecimentos, agarrava-se ao sentimento de lealdade ao rei e à religião. ${ }^{105}$

Na manhã de 19 de abril de 1810 uma sessão extraordinária do Conselho Municipal foi convocada e a população chamada para reunião na Praça Central. O ato em si já representava uma sublevação da ordem, uma vez que o Conselho se reuniu ilegalmente, sem convocação prévia do Capitão Geral, o único com prerrogativas para tanto. Este, sem apoio, viu-se obrigado à renunciar ao governo da província. ${ }^{106}$ Assim, Caracas ficou sem a representação da autoridade metropolitana. O Conselho constituiu uma Junta Suprema de Governo com a admissão de pessoas autointituladas representantes dos mais diversos setores daquela sociedade. Na nota de publicação da Ata de tal Assembleia, o novo governo é saudado como representante do povo em nome de Fernando VII:

\begin{abstract}
“En el mismo día, por disposición de lo que se manda en el acuerdo que antecede, se hizo publicación de éste en los parajes más públicos de esta ciudad, con general aplauso y aclamaciones del pueblo, diciendo: ¡Viva nuestro rey Fernando VII, nuevo Gobierno, muy ilustre Ayuntamiento y diputados del pueblo que lo representan!"107
\end{abstract}

\footnotetext{
${ }^{105}$ PARRA-PEREZ, Caracciolo. op. cit., p. 379-381.

${ }^{106}$ As forças armadas, sob o comando de oficiais criollos vinculados às grandes propriedades - como a família del Toro - tiveram papel determinante na renúncia do governador Emparan. Sobre a Junta de Caracas e as forças armadas: THIBAUD, Clément. Repúblicas en armas. Los ejércitos bolivarianos en guerra de Independencia en Colômbia y Venezuela. Bogotá: Editorial Planeta, 2003, p. 44-53.

${ }^{107}$ Documento reproduzido integralmente pela Biblioteca Virtual Miguel de Cervantes: http://www.cervantesvirtual.com/servlet/SirveObras/04700741222647284199079/index.htm
} 
O documento deixa clara a urgência de uma resposta prática ao agravamento da crise de governo diante do total subjugo da Espanha pelas forças francesas:

"En la ciudad de Caracas a 19 de abril de 1810, se juntaron en esta sala capitular los señores que abajo firmarán, y son los que componen este muy ilustre Ayuntamiento, con motivo (...) principalmente con el de atender a la salud pública de este pueblo que se halla en total orfandad, no sólo por el cautiverio del señor Don Fernando VII, sino también por haberse disuelto la junta que suplía su ausencia en todo lo tocante a la seguridad y defensa de sus dominios invadidos por el Emperador de los franceses, y demás urgencias de primera necesidad, a consecuencia de la ocupación casi total de los reinos y provincias de España, de donde ha resultado la dispersión de todos o casi todos los que componían la expresada junta y, por consiguiente, el cese de su funciones. Y aunque, según las últimas o penúltimas noticias derivadas de Cádiz, parece haberse sustituido otra forma de gobierno con el título de Regencia, sea lo que fuese de la certeza o incertidumbre de este hecho, y de la nulidad de su formación, no puede ejercer ningún mando ni jurisdicción sobre estos países, porque ni ha sido constituido por el voto de estos fieles habitantes, cuando han sido ya declarados, no colonos, sino partes integrantes de la Corona de España, y como tales han sido llamados al ejercicio de la soberanía interina, y a la reforma de la constitución nacional; (...) el indicado nuevo gobierno, en cuyo caso el derecho natural y todos los demás dictan la necesidad de procurar los medios de su conservación y defensa; y de erigir en el seno mismo de estos países un sistema de gobierno que supla las 
enunciadas faltas, ejerciendo los derechos de la soberanía, que por el mismo hecho ha recaído en el pueblo, conforme a los mismos principios de la sabia Constitución primitiva de España, y a las máximas que ha enseñando y publicado en innumerables papeles la junta suprema extinguida". 108

Esta Junta enviou emissários às principais cidades da Província de Caracas ${ }^{109}$ e das demais províncias, em busca de adesão ao movimento de ruptura com a metrópole. Alguns conselhos municipais encaminharam delegados à Junta Central, constituindo assim, em nome do rei cativo, o primeiro governo da Venezuela autônomo em relação a administração peninsular. Outros negaram a autoridade da Junta caraquenha. Em Coro, por exemplo, declararam mais do que nunca, permanecer fiéis às leis e rechaçar a usurpação do governo formado em Caracas "por ímpios rebeldes", ordenando a prisão dos enviados da Junta Suprema. Também Maracaibo e Guayana manifestaram o desejo de permanecerem obedientes ao governo espanhol. Havia entre os homens de governo na Venezuela uma visão partilhada por todos quanto aos direitos de Fernando VII e a luta contra Napoleão, porém discordavam sobre a solução mais adequada à crise instaurada.

Dessa maneira, entre adesões e rechaços, nas eleições para deputados, no mês de novembro, a província de Caracas nomeou vinte e quatro representantes; Barinas, nove; Cumaná, quatro; Barcelona, três; Mérida, três; Trujillo, um; e Margarita mais um. No dia 02 de março de 1811, destes quarenta e cinco deputados, trinta se

\footnotetext{
${ }^{108}$ Ibdem: http://www.cervantesvirtual.com/servlet/SirveObras/04700741222647284199079/index.htm

${ }^{109}$ Mapa com representação dos territórios provinciais da Venezuela: Anexo 2.
} 
reuniram em Caracas e instalaram o Congresso Geral de Venezuela. ${ }^{110}$ Estes deputados instauraram um sistema federativo de governo jurando:

“(...) à la pátria conservar y defender sus derechos y los del Señor don Fernando VII, sin la menor relacion, ò influxo con la Francia; independientes de toda forma de Gobierno de la Península de Espana; y sin otra representacion que la que residen el Congresso General de Venezuela". ${ }^{111}$

A constituição do Congresso Geral da Venezuela, e os demais governos autônomos formados na América hispânica, mesmo sob juramento de fidelidade ao monarca espanhol impedido, estabeleciam, na prática, uma alternativa ao governo metropolitano. Processo que se mostraria irreversível num futuro muito próximo. Dessa maneira, mesmo não se tratando de uma ruptura premeditada, os acontecimentos de 1810 foram permeados por uma dimensão de continuidade, tornando-os menos imprevisíveis do que os de 1808 para os homens vinculados à administração colonial. Segundo Halperin Donghi, "para magistrados, militares, clérigos e os notáveis com direito a voto, 1810 não foi surpresa maior que 1808; o ocorrido nesta data - com um poder metropolitano demasiadamente débil tanto na metrópole como para arbitrar entre as distintas forças rivais nas colônias - lhes havia ensinado que qualquer nova crise na relação com a metrópole podia ter consequências irrevogáveis sobre sua própria posição nas Índias, razão para adotar uma atitude menos passiva frente a provável crise". ${ }^{112}$

\footnotetext{
${ }^{110}$ A relação dos deputados eleitos por província publicada na Gazeta de Caracas de 19 de fevereiro de 1811 e, na edição de 5 de março de 1811, junto ao anúncio da instalação do Congresso, a lista dos nomes dos presentes. In.: Gazeta de Caracas, op. cit., vol. 2.

${ }^{111}$ Gazeta de Caracas, n. ${ }^{\circ}$ 22, 05 de março de 1811, op. cit., vol. 2.

${ }^{112}$ HALPERIN DONGHI, op. cit., p. 123 (tradução livre).
} 
No caso da Venezuela, as províncias de Maracaibo, Coro e Guayana se mantiveram obedientes ao governo espanhol peninsular, que em breve contaria com os recursos destas regiões para reação realista.

Ainda em 1810, a Junta de Governo encaminhara a Londres uma comitiva em busca de apoio, ou ao menos de neutralidade, de S. M. Britânica em relação ao governo autônomo da Venezuela. Entre os comissários, Simón Bolívar - então com vinte e seis anos, e nomeado coronel pela mesma Junta -, que contrariando as instruções que recebera, empenhou-se no regresso do general Francisco de Miranda a Caracas. As tensões internas do congresso recém-instituído, sobre a gerência política do país, foram aumentadas pela presença de Miranda. Por causa das investidas comandadas por ele em 1806, era considerado por alguns como traidor do rei, e frequentemente relacionado ao radicalismo francês. Mas nenhuma objeção o impediu de participar direta ou indiretamente dos processos decisórios. Miranda resolveu apoiar-se na Sociedade Patriótica como instrumento da execução de um plano pela independência política venezuelana.

A situação interna de governo, já conflituosa, progrediu para o enfrentamento entre as tendências no Congresso: os partidários da Sociedade Patriótica defendiam o rompimento definitivo com a monarquia espanhola, enfrentando a resistência de muitos deputados, uns por se negarem a faltar com o juramento de fidelidade ao soberano espanhol, e outros porque temiam uma repercussão internacional que prejudicasse a economia e comércio das províncias. A dita Sociedade venceu as eleições, conseguindo a presidência da Casa; os chamados "homens de Miranda" (Simón Bolívar, Coto Paul, Pena, García de Sena, José Feliz Ribas, Muñoz Tébar, os Carabaños, os Salias, Soublette, Sanz de Buroz, entre outros) tomam a direção do movimento pela autonomia política do país. 
Neste sentido, os desdobramentos deste processo na Venezuela explicitam a realidade comum de toda América Espanhola: a necessidade de resposta urgente à instabilidade consequente da indefinição na esfera política, viabilizou ação de pequenos grupos, - mas nada desdenháveis, considerando que frequentemente pertenciam à camada da sociedade com grandes propriedades, como o próprio Bolívar - desenvolvidos a partir da difusão de novos valores emergentes de espaços diferenciados de sociabilidade, que propiciaram a irrupção de mutações múltiplas no campo das ideias, do imaginário, dos valores e dos comportamentos, que se opunham aos padrões praticados no chamado sistema de Antigo Regime.

Assim, na Venezuela, os homens orientados por esses valores "modernos", norteados pela ideia do direito natural de liberdade, trilharam muito rapidamente um caminho em direção ao total rompimento com a Espanha e seu monarca, nesta altura já incapaz "de gobernar estos Pueblos bajo principios de justicia, aunque quisiera". 113 Em 5 de julho de 1811 declarou-se, formalmente, a Independência da Venezuela.

Apesar da declaração de independência não instaurar de maneira formal uma República - prudência explicada pelo posicionamento de lealdade ao monarca mantido pela maioria da população ${ }^{114}$-, o período inaugurado é tratado pela historiografia venezuelana como a Primeira República. Afinal, a soberania, reassumida pelo "povo", era exercida por meio de seus supostos representantes:

"Nosotros, pues, a nombre y con la voluntad y autoridad que tenemos del virtuoso pueblo de Venezuela, declaramos solemnemente al mundo que sus Provincias Unidas son, y deben ser desde hoy, de hecho y de derecho, Estados libres, soberanos e

\footnotetext{
${ }^{113}$ Declaração de Independência da Venezuela. In.: Gazeta de Caracas, 9 de julho de 1811, op. cit.

${ }^{114}$ THIBAUD, Clément. Repúblicas en armas, op. cit., p. 64-72 passim
} 
independientes y que están absueltos de toda sumisión y dependencia de la Corona de España o de los que se dicen o dijeren sus apoderados o representantes, y que como tal Estado libre e independiente tiene un pleno poder para darse la forma de gobierno que sea conforme a la voluntad general de sus pueblos.",115

A partir de então, a indiscutível autoridade do monarca espanhol, a quem deviam fidelidade, se converteu em símbolo da arbitrariedade e incapacidade de governo:

“América volvió a existir de nuevo, desde que pudo y debió tomar a su cargo su suerte y conservación; como España pudo reconocer, o no, los derechos de un rey que había apreciado más su existencia que la dignidad de la nación que gobernaba.

Cuantos Borbones concurrieron a las inválidas estipulaciones de Bayona, abandonando el territorio español, contra la voluntad de los pueblos, faltaron, despreciaron y hollaron el deber sagrado que contrajeron con los españoles de ambos mundos, cuando, con su sangre y sus tesoros, los colocaron en el trono a despecho de la Casa de Austria; por esta conducta quedaron inhábiles e incapaces de

${ }^{115}$ Acta de la Independencia de Venezuela. In.: Gazeta de Caracas, 16 de julho de 1811, op. cit., vol. 3. Embora o termo "povo" fosse utilizado de forma indiscriminada nos discursos, na Venezuela, em princípios do século XIX, o voto era censitário, um direito reservado aos homens brancos proprietários, com patrimônio a partir de dois mil pesos. Vide: HALPERIN DONGHI, Tulio, op. cit., p. 137. SALCEDO-BASTARDO, José Luis. Historia fundamental de Venezuela, op. cit., p. 239: "La democracia criolla que se pretendia implantar seméjase a la de Atenas, avanzada en las superficialidades y admirable en el juego de la esclarecida minoria autodenominada povo, cuyo ejercicio público era, sin embargo, sostenido por el trabajo esclavista". Sobre organização da sociedade da Venezula no início do século XIX: IZARD, Miguel. El miedo a la Revolucion. La lucha por la libertad en Venezuela (1777-1830). Madri: Editorial Tecnos, 1979, capítulo 2. 
gobernar a un pueblo libre, a quien entregaron como un rebaño de esclavos". 116

Assim, a causa da Independência da Venezuela ganhou feições de guerra. Expedições realistas orientadas pela metrópole foram enviadas para América. As forças armadas da jovem República contavam com milícias urbanas e a formação de batalhões a partir de uma política de promoções que ignorou as fronteiras sociais estabelecidas até então. Abriu-se a oportunidade para obtenção de posições, salários e prestígios até então inacessíveis para algumas camadas daquela sociedade. ${ }^{117}$ Contudo, estes esforços não foram suficientes para impedir a vitória realista no ano seguinte, e a força da reação metropolitana não foi o único motivo para a efêmera duração da Primeira República da Venezuela.

Seu fim também se deveu à instabilidade interna do movimento independentista. As querelas entre os grupos opositores, que não se preocupavam em medir as consequências de suas posições nas filas republicanas - imaginando trabalhar, segundo ideais e métodos diferentes, pelo triunfo da causa comum - seria uma das razões principais do fim da primeira experiência republicana na Venezuela. ${ }^{118}$ Segundo Parra-Perez, somam-se ao insucesso a inabilidade do governo com as contas públicas, medidas que se chocavam com os interesses econômicos de alguns ${ }^{119}$ e com a religiosidade da maioria. Quintero traz luz à questão, identificando contradições de outra natureza ao analisar a constituição da Primeira República da

\footnotetext{
${ }^{116}$ Acta de la Independencia de Venezuela. In.: Gazeta de Caracas, 16 de julho de 1811, op. cit.. Sobre liberdade nos discursos da Primera República: CASTRO LEIVA, Luis. La elocuencia de la libertad. In.: Idem. De la patria boba a la teologia bolivariana. Obras, vol. 1, Caracas: Fundación Polar Universidad Católica Andrés Bello, 2005, p. 185-250.

${ }^{117}$ THIBAUD, Clément. Repúblicas en armas, op. cit., p. 52-53.

118 PARRA-PEREZ, C.. Historia de la primera República de Venezuela, vol. 2, op. cit., p. 32-33.

${ }^{119} \mathrm{Em} 14$ de maio de 1811, Miranda decretou lei que ofereceu liberdade aos escravos que se alistassem no exército e servissem à causa republicana por dez anos. Esta medida provou a reação dos grandes proprietários contra o regime. PARRA-PEREZ, op. cit., p. 308-309.
} 
Venezuela como ato coordenado por um grupo reduzido de criollos, assinalando que a decisão de desprendimento do reino espanhol e a construção de uma nova nação se deram a partir de premissas radicalmente opostas às práticas políticas, culturais e sociais vigentes há trezentos anos. Por isso a ruptura proposta pelo movimento republicano, inevitavelmente, gerou as mais compreensíveis reservas e os mais acirrados enfrentamentos. ${ }^{120}$ Thibaud assinala outro fator importante para o desfecho contrário ao movimento pró-independência: a dificuldade em definir a identidade do inimigo. Para que a causa ganhasse contornos de nacional, o opositor necessariamente precisaria ser identificado como estrangeiro, mas não o era - o combate entre as cidades rivais foi mais determinante do que a ação realista neste primeiro momento da guerra. $^{121}$ Neste contexto de completa instabilidade, soma-se a desolação, consequente das batalhas, espalhadas por todo o território venezuelano, estabelecendo um panorama favorável a demonstrações contrárias à ação independentista.

Assim, a agonizante República ficou em situação praticamente irremediável após o terremoto de 26 de março de 1812, que arrasou quase todo o país. Em junho, o golpe final foi a tomada de Porto Cabello, ${ }^{122}$ uma das principais bases de operações republicanas e porta de entrada de armas e demais socorros estrangeiros, pelas forças realistas comandadas por Monteverde. Esta seria a primeira grande derrota do então coronel Simón Bolívar.

Assumindo o fracasso do movimento pró-independência, o general Miranda negociou sua rendição e, em 30 de julho de 1812, os realistas retomaram Caracas. Evidentemente, não foi este um ato consensual entre seus membros. No mesmo dia

\footnotetext{
${ }^{120}$ QUINTERO, Inês. Un salto en el abismo. In.: Biblioteca electrónica (julho/2000): http://www.analitica.com/bitBlioteca/venezuela/5julio.asp

${ }^{121}$ THIBAUD, Clément. Repúblicas en armas, op. cit., p. 93-97.

122 Sobre batalhas durante a "Primeira República": PARRA-PEREZ, Caracciolo. Historia de la primera Republica de Venezuela, volume 2, op. cit., p. 235-381; MIJARES, Augusto. El Libertador, op. cit., p. 203-221, SALCEDO-BASTARDO, José Luis, op. cit., p. 241-252.
} 
em que as forças comandadas por Monteverde entraram em Caracas, um segmento do movimento republicano condenava Miranda por traição. Na noite de 31 de julho, alguns oficiais liderados por Simón Bolívar prenderam o general momentos antes de seu embarque, em La Guairá. ${ }^{123}$

Halperin Donghi resume a Primeira República como um governo em que o poder era zelosamente monopolizado e internamente dividido por uma oligarquia fechada, cuja trajetória teve duas principais consequências: o impedimento da possibilidade de uma nova ordem ganhar a simpatia dos populares, pois os excluía, e a perda de toda possibilidade de proteção que poderia salvar a República durante a luta. $^{124}$

A partir da assinatura da rendição, o momento foi de forte perseguição aos participantes da iniciativa republicana. Assim como os demais oficiais, Bolívar saiu da Venezuela em busca de exílio. Em setembro, conseguiu chegar a Curazao, e desta ilha mudou-se, em outubro, para Cartagena - em Nova Granada -, onde redefiniu sua proposta política, expressa no manifesto de 15 de dezembro de $1812 .^{125}$ Dessa maneira, simultaneamente buscava apoio para uma nova investida em território venezuelano, e introduzia um plano conjunto para independência dos territórios:

"La Nueva Granada ha visto sucumbir a Venezuela, por consiguiente debe evitar los escollos que han destrozado a aquélla. A este efecto presento como una medida indispensable para la seguridad de la Nueva Granada la reconquista de Caracas. A primera vista parecerá este proyecto inconducente, costoso y quizás impracticable; pero

\footnotetext{
${ }^{123}$ O General foi encaminhado a julgamento militar. Manuel María Casas entregou o ilustre prisioneiro aos espanhóis. No final de 1814 Miranda foi transferido para Espanha, onde faleceu dois anos depois, na prisão de La Carraca, em Cádiz.

${ }^{124}$ HALPERIN DONGHI, Tulio, op. cit., p. 139.

${ }^{125}$ Memoria dirigida a los ciudadanos de la Nueva Granada por un caraqueño. Cartagena, 12 de dezembro de 1812. In.: Cartas del Libertador, Tomo 1, Caracas: Vicente Lecuna, 1964, p. 57-66.
} 
examinando atentamente con ojos previsivos, y una meditación profunda, es imposible desconocer su necesidad, como dejar de ponerlo en ejecución probada la utilidad”. ${ }^{126}$

Simón Bolívar conseguiu reunir recursos suficientes para, no final daquele mesmo ano, retomar as batalhas contra grupos realistas na região do rio Magdalena em Nova Granada. Vitorioso, em maio de 1813, alcançou Cúcuta, na fronteira com a Venezuela, de onde iniciou mais uma sequência de campanhas vitoriosas e, em julho, avançou sobre Mérida, onde foi aclamado Libertador. De vitória em vitória, entrou triunfante em Caracas, no mês de agosto. Assim, o oficial vencido de Puerto Cabello se converteu em líder do processo de Independência da Venezuela. Em 14 de outubro de 1813, o Conselho Municipal de Caracas foi novamente convocado extraordinariamente, e nesta sessão Bolívar foi nomeado “capitão-general do exército e Libertador". Organizou-se um novo governo, e foram concedidos a Bolívar plenos poderes. Inaugura-se a Segunda República com as províncias de Maracaibo e Guayana ainda sob domínio realista.

Contudo, o futuro do país, assim como o de toda a América hispânica, ainda era incerto. A reação realista não é toda vencida: com o apoio das províncias de Maracaibo, no norte, de Guayana, no sul, conseguem constantes e renovadas energias (humanas e econômicas). Por estas províncias entrava o imprescindível material de guerra que vinha de Porto Rico, Cuba e das ilhas inglesas para reforço dos efetivos metropolitanos. ${ }^{127} \mathrm{E}$, pela segunda vez, o movimento pró-independência fracassaria na tentativa de ampliar sua base de apoio. Neste sentido, as forças realistas também

\footnotetext{
${ }^{126}$ Ibdem, p. 63

${ }^{127}$ SALCEDO-BASTARDO, op. cit., p. 246.
} 
tiveram maior êxito: a ação dos llaneros ${ }^{128}$ chefiados José Tomás Boves, foi decisiva para vitória dos defensores da antiga ordem sobre a Segunda República, forçando Bolívar a novo retiro em Cartagena, em setembro de 1814.

Alguns esforços da historiografia venezuelana no sentido de desvendar um possível conteúdo social no alçamento dos llaneros não são de todo convincentes. Como assinalado por Carrera Damas, o movimento não foi inspirado por nenhum desejo de terra, pois os "pastores de gado" mal podiam ver nestes termos o problema de sua inserção na economia daquele território. Para o autor, a Primeira República havia "lançado sobre os Llanos os dardos de uma legislação destinada a fixar os direitos de propriedade e os deveres dos peões sem terra, perigosa não só para os últimos, pois muitos dos grandes proprietários de gado pastavam seus rebanhos em terras sem dono, e a maioria dos proprietários das terras se apoiavam em títulos duvidosos". ${ }^{129}$ Assim, ainda sob os ecos da Primeira, a Segunda República da Venezuela também se sustentou por pouco tempo. No mesmo sentido, em toda América espanhola, poderes locais buscavam alternativas políticas, edificando novas possibilidades de governo sobre a ruína do vínculo colonial. ${ }^{130}$

O mundo luso-americano acompanhava atentamente estes ruidosos movimentos. A irrupção de novas configurações políticas na América espanhola, a partir de 1810, agravaria os temores relativos às condições de manutenção da ordem dinástica no interior da unidade imperial portuguesa, tornando mais complexa a

\footnotetext{
${ }^{128}$ Peões provenientes dos Llanos - planície que ocupa grande parte do território ao norte da Venezuela.

${ }^{129}$ CARRERA DAMAS, Germán. Boves: aspectos socioeconômicos de las guerras de Independência, $3^{a}$ ed., Caracas: 1972. Citado por HALPERIN DONGHI, Túlio, op. cit., p.141 (tradução livre). Vide também THIBAUD, Clément. De la ficción al mito: los llaneros de la Independencia de Venezuela. In.: CARRERA DAMAS, Germán, et al. Mitos politicos en las sociedades andinas: orígenes, invenciones y ficciones. Paris/Caracas/Lima: IFEA: 2006; THIBAUD, Clément. Repúblicas en armas, op. cit., p. 149-181.

130 HALPERIN DONGHI, Tulio. op. cit., p. 122-150; LYNCH, John. Las revoluciones hispanoamericanas 1808-1826. $8^{\mathrm{a}}$ ed. Barcelona: Ariel, 2001.
} 
interação entre as duas Américas, "uma cada vez menos realista, a outra procurando manter-se como tal". ${ }^{131}$

Embora os homens de Estado do Império português estivessem bem informados sobre a situação na vizinhança hispânica, os eventos inaugurados em 1810 seriam cuidadosamente silenciados pelo veículo oficial de imprensa do governo, a Gazeta do Rio de Janeiro. Eram somente circunstancialmente evocados, aparentemente em busca de um resguardo do mundo português perante um influxo de exemplos e experiências cujos resultados, no Brasil, eram ainda incertos. O silêncio da Gazeta é prova sintomática de como a experiência hispano-americana, a partir de 1810, era condicionante da própria trajetória política da América portuguesa. ${ }^{132}$

Dessa maneira, a difusão pública de tais acontecimentos dependeria quase exclusivamente do Correio Braziliense, que em junho de 1810 já noticiava os acontecimentos de Caracas:

“(...) recebeu o nosso Governo despachos da Ilha de Curaçao, em que se refere que os habitantes de Caracas proclamaram sua independência. Informados da irrupção dos franceses na Andaluzia, de terem ocupado Sevilha, e da precipitada fuga da Junta daquela cidade, e das preparações que se faziam para tomar Cádiz, concluíram que tudo estava perdido, na metrópole; e imediatamente adotaram as medidas que julgaram mais convenientes para assegurar a um tão florescente estabelecimento alguma coisa semelhante à existência política". ${ }^{133}$

\footnotetext{
${ }^{131}$ PIMENTA, João Paulo Garrido. O Brasil e a América Espanhola (1808-1822), op. cit., p. 73.

${ }^{132}$ Sobre o silêncio da Gazeta do Rio de Janeiro: Ibdem, p. 103-105.

${ }^{133}$ Correio Braziliense n. ${ }^{\circ}$ 25, junho de 1810, op. cit., vol. 4, p. 639-640.
} 
$\mathrm{Na}$ edição seguinte, dedicou longo espaço à reprodução de documentos informativos sobre as ocorrências na Venezuela: em um extrato da Gazeta de Caracas se anunciava a formação da Junta de Governo, uma proclamação deste Governo provisório, um manifesto justificando seus procedimentos, uma carta da Junta Suprema de Caracas à Junta Superior de Governo em Cádiz, a resposta de Cádiz a esta correspondência, uma “Ordem da Regência de Espanha ao Capitão General de Caracas" e a respostada de Caracas a esta última. ${ }^{134}$

Os primeiros pareceres de Hipólito da Costa sobre as Juntas de governo hispano-americanas, consideravam as iniciativas justas, quase inevitáveis:

“(...) achando-se a imensa população da América espanhola, sem governo algum, é da natureza das coisas, que procedam a formar um, que melhor convenha à sua situação. (...) é chegado o tempo, em que a forçosa necessidade obriga a tomar uma resolução". ${ }^{135}$

Dois meses depois, reafirmando sua posição:

"A justiça deste modo de proceder nos parece evidente; porque não há mais razão para supor que a província de Caracas ou outra qualquer da América Espanhola se deva submeter ao Governo da província da Galiza, ou de Andaluzia ou de outra qualquer província europeia (...); pois é evidente que faltando o soberano a nação devia escolher um Governo (...)". ${ }^{136}$

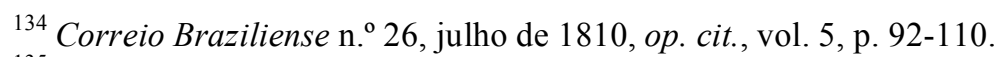

${ }_{135}$ Correio Braziliense n. ${ }^{\circ}$ 22, março de 1810, op. cit., vol. 4, p. 305-306.

${ }^{136}$ Correio Braziliense n. ${ }^{\circ}$ 25, junho de 1810, op. cit., vol. 4, p. 663.
} 
Não só pela orfandade da América espanhola, devido à ausência do rei, justificava o Correio as iniciativas dos novos governos. Seu pensamento reformista fica claro nas críticas ao mau governo espanhol:

"Cansados os caraquenhos de sofrer uma longa série de despotismos de seus Governadores, que se agravavam cada dia mais pela fraqueza, inépcia, do Governo da Metrópole, determinaram escolher, e constituir, uma forma de governo que melhor conviesse para procurar a felicidade comum. (...). As muitas Províncias da América Espanhola, que já se uniram a Caracas, nesta resolução da independência, mostram, que não se limita a província de Venezuela esta notável determinação". 137

No ano seguinte, sobre os desdobramentos dos processos, o Correio Brasilienze, frequentemente, atribuiu ao mau governo metropolitano espanhol a situação das respectivas colônias. Sobre Caracas, em março de 1811, escreveu:

"Nós não podemos ver, sem sumo desgosto, os progressos desta guerra civil, que, suposto seja em algum grão motivada pela ambição de alguns integrantes, e principalmente devida à má política que tem seguido a Metrópole”. 138

Ao se empenhar em "dar uma completa ideia das causas e fins desta importante revolução,"139 o periódico não só informava, mas também propunha a

${ }^{137}$ Correio Braziliense n. ${ }^{\circ}$ 28, setembro de 1810, op. cit., vol. 5, p. 118-119

${ }^{138}$ Correio Braziliense n. ${ }^{\circ}$ 34, março de 1811, op. cit., vol. 6, p. 300

${ }^{139}$ Correio Braziliense n. $^{\circ}$ 26, julho de 1810, op . cit., vol. 5, p. 118. Vários documentos relacionados ao estabelecimento da "Juncta Central de Venezuela" foram reproduzidos na mesma edição - p. 78 et seq. 
reflexão sobre todos os eventos da vizinhança hispânica. O processo vizinho poderia ser o perfeito exemplo das consequências de uma administração equivocada, podendo servir de alerta ao governo português.

Ao sul, em 25 de maio daquele mesmo ano de 1810, estabeleceu-se em Buenos Aires a "Junta Provisional Gubernativa de las Provincias del Río de la Plata a nombre del Señor Don Fernando VII", que, tal qual as demais formadas na América espanhola, rompeu com a lógica absolutista representando uma alternativa de governo - até então não considerada efetivamente. Desse modo, a solução carlotista deixaria, gradativa mas rapidamente, de ser uma opção viável. Também as tentativas de acordo com Montevidéu, Alto Peru e Paraguai, que conservaram-se fiéis ao governo espanhol e não reconheceram a autoridade da Junta de Buenos Aires, malograram.

Assim, só aumentavam os temores, do governo português, causados pelas notícias dos desdobramentos de processos independentistas em suas fronteiras. Em ofício de 26 de fevereiro de 1811, o ministro português, D. Rodrigo de Sousa Coutinho, registrou:

"Sobre a probabilidade de que Montevidéu se entregue e se una enfim a Buenos Aires, me dá o maior cuidado, pois vejo que o único partido que se poderia tomar é aquele que se não há de abraçar e aquele que também não é isento de grandes embaraços e terríveis dificuldades. Temo que o ódio, receio e animosidade dos Espanhóis contra os Portugueses assim como o seu estúpido orgulho ponha um terrível obstáculo a que se unam com Vossa Alteza Real e que 
consintam assim em que ponha um freio à Revolução de Buenos Aires e que se salvem os interesses da Monarquia". 140

Este processo desenrolou-se para ação militar em junho do mesmo ano, quando as tropas estacionadas no Rio Grande do Sul receberam ordens para agir no território objetivando "salvar e pacificar o território desta banda do Uruguai". ${ }^{141}$ Esta iniciativa foi vista com apreensão tanto por Montevidéu como por Buenos Aires, temerosos de uma tentativa de anexação à América portuguesa. Assim, as duas cidades platinas se viram obrigadas ao armistício, assinado em Montevidéu no dia 20 de outubro daquele mesmo ano. Para o governo luso-americano, o acordo representou a vantagem do enfraquecimento de Buenos Aires, evitando a ameaça do estabelecimento de seu domínio na margem esquerda do Prata; mas para as pretensões de Sousa Coutinho, outrora articulista de interesses britânicos em torno do projeto carlotista, significou uma derrota.

Ainda sobre a política externa, é necessário destacar o alinhamento do estado português à Grã-Bretanha, elemento essencial na determinação de suas relações internacionais e, por isso, das suas condições de reação aos vetores impostos pela América espanhola. Em fevereiro de 1810, foram assinados os tratados de comércio e aliança com os britânicos, que na essência definiam a troca do escoamento da produção luso-americana - num momento em que os mercados do continente europeu estavam bloqueados por Napoleão - pela liberação da entrada dos artigos manufaturados britânicos no Brasil. A reciprocidade não era completa, porque o Brasil, concedendo um regime de privilégio, recebia apenas o tratamento de nação

\footnotetext{
${ }^{140}$ Ofício de 26 de fevereiro de 1811. Citado por ALEXANDRE, Valentim. Os sentidos do Império, op. cit., p. 249.

${ }^{141}$ Ordem Régia participada pelo Conde de Linhares, Ministro e Secretário de Estado de S.A.R. o Príncipe Regente de Portugal ao Governador e Capitão General do Rio Grande. Rio de Janeiro, 6 de junho de 1811. In.: Correio Braziliense, n..$^{\circ}$ 43, dezembro de 1811, op. cit., vol. 7, p. 709-710.
} 
mais favorecida; "mas essa diferença de condições perdia importância no curto prazo, até porque, de qualquer forma, a Grã-Bretanha teria sempre uma posição dominante no comércio brasileiro, enquanto durasse a guerra na Europa."142 Entretanto, num prazo maior, o tratado promoveria a alteração estrutural do quadro econômico em que até então se desenvolvera o império português. No período entre os anos de 1808 a 1812, a política econômica portuguesa se revestiria de um reformismo alinhado aos interesses britânicos, tentando adapta-se a um regime livre - cambista.

O ponto mais polêmico dos tratados, e o de maior motivo de desacordos, era o relativo a escravidão. ${ }^{143} \mathrm{O}$ governo lusitano se comprometera em cooperar para extinção do comércio de mão-de-obra escrava. Porém, admitia a escravidão como indispensável à economia do Brasil e, consequentemente, a de todo o reino de Portugal; portanto, a abolição dependeria de um processo gradativo. O governo português considerava os termos negociados amplos o suficiente para permitir a continuação indefinida do tráfico nas regiões onde até então já era praticado. Por outro lado, os ingleses não tardaram em apresar os navios negreiros portugueses. Em suas memórias, Saldanha da Gama, ministro plenipotenciário português, quando se referiu às ações britânicas em portos do Brasil, assinalou: "quando se recebeu no Brasil a notícia do apresamento dos primeiros navios, julgou-se geralmente que isso provinha do capricho do comandante de algum corsário, e que o Governo Britânico daria dentro em breve uma satisfação completa de seus atos, supostos arbitrários; mas os avisos consecutivos que se receberam de outros acontecimentos idênticos

\footnotetext{
${ }^{142}$ ALEXANDRE, Valentim. Os sentidos do Império, op. cit., p. 226. O autor analisou a Carta Régia de março de 1810 destacando as doutrinas do liberalismo econômico em seus argumentos - p. 232-241.

${ }^{143} \mathrm{Ibdem}$, p. 209-232.
} 
espalharam o susto, principalmente entre os habitantes da Bahia, os quais romperam em sérias demonstrações de descontentamento (...)". ${ }^{144}$

Nos anos seguintes, a imprensa refletiu o descontentamento geral e colaborou com o aumento das tensões com duras críticas aos efeitos do acordo. Hipólito da Costa, o principal e mais eloquente crítico da administração portuguesa, publicou na edição n 49 do Correio Braziliense a "Relação das Embarcações Portuguesas que têm sido tomadas pelos Ingleses" entre os anos de 1811 e $1812 .{ }^{145}$ O Investigador Português em Inglaterra, em setembro de 1814, numa crítica sobre os artigos do acordo de 1810, acusa-o de causar à "Nação Portuguesa um prejuízo muito maior do que lhe teria causado a invasão de um exército inimigo". ${ }^{146}$ As pressões eram claras e as tensões crescentes. A administração lusitana seguiu com uma política que objetivava contornar situações, pois como já assinalado, Portugal dificilmente poderia encontrar no sistema internacional, até o final dos conflitos na Europa, forças para oferecer contrapeso à influência britânica.

Apesar dos protestos e descontentamentos acumulados pelos súditos portugueses, os tratados de 1810 alinhavam Portugal e Brasil à política hegemônica mundial - mesmo que, evidentemente, em condição desfavorável. Para a burocracia imperial bragantina, o principal objetivo da aliança com a Grã-Bretanha era salvaguardar a unidade política de seus domínios na América. Afinal, a iniciativa da

${ }^{144}$ GAMA, Antônio Saldanha da, o conde do Porto Santo. Memória Histórica e política sobre o comércio da escravatura entregue no dia 2 de novembro de 1816 ao conde Capo D'Istria, ministro do imperador da Rússia. Lisboa: Imprensa Nacional, 1880. Citado por ALEXANDRE, Valentim, op. cit., p. 270. Saldanha da Gama (1778-1839), lisboeta que desempenhou vários cargos administrativos e diplomáticos do governo português, aos vinte e quatro anos, foi nomeado Capitão-geral do Maranhão (1802), em seguida, Conselheiro do Ultramar (1806), foi Governador Geral de Angola (1807), Conselheiro da Fazenda no Brasil (1810) e integrou a representação portuguesa no Congresso de Viena como ministro plenipotenciário (1814-1815). Quando escreveu suas memórias, exercia a função de ministro plenipotenciário em São Petersburgo (1815). Fonte: Secretaria Geral do Ministério das Finanças e da Administração Pública de Portugal. In: www.sgmf.pt/.../986f54ba22924e958d2b4d53584be561DAntóniodeSaldanhadaGama1.pdf ${ }^{145}$ Correio Braziliense, n. ${ }^{\circ} 49$, junho de 1812, op. cit, vol. 8, p. 746.

${ }^{146}$ O Investigador Português, n..$^{\circ}$ 27, setembro de 1814, p. 412. Citado por ALEXANDRE, Valentim, op. cit., p. 265. 
Província de Caracas, em abril de 1810, foi apenas o primeiro sinal de um processo que levaria toda América espanhola à trilha da ruptura política com sua metrópole, tornando "possível à América portuguesa construir, a partir dos exemplos vizinhos, uma experiência". ${ }^{147}$ De momento, porém, isso era apenas - e cada vez mais aventado.

2.3- O fim do domínio napoleônico: Brasil e Venezuela na tentativa de reordenação do mundo ibérico (1814-1816)

Derrotadas as forças napoleônicas, os representantes das potências europeias, com exceção da Turquia, se reuniram na capital austríaca - entre 1 de outubro de 1814 e 9 de junho de 1815 - com o objetivo de negociar o novo mapa político da Europa, restaurando os princípios das monarquias absolutistas e estabelecendo mecanismos para suas defesas. Neste sentido, a Santa Aliança - criada por Áustria, Prússia e Rússia -, com direito a intervenção militar objetivando a defesa mútua e a manutenção das coroas europeias, foi uma das consequências imediatas do Congresso de Viena. Os parâmetros das negociações foram estabelecidos pela hierarquia política vigente na época, com prioridade para Grã-Bretanha, França e Rússia, e em menor medida, Áustria e Prússia. ${ }^{148}$ Assim, os Estados ibéricos, em meio à crise interna e em condição desfavorável no arranjo político europeu, concentrariam suas forças em conciliar o alinhamento com a Grã-Bretanha com ações que os salvaguardassem no continente americano. $^{149}$

\footnotetext{
${ }^{147}$ PIMENTA, João Paulo Garrido. O Brasil e a América Espanhola (1808-1822), op. cit., p. 147. ${ }^{148}$ HOBSBAWM, Eric J.. A Era das Revoluções, $10^{\mathrm{a}}$ ed., São Paulo: Paz e Terra, 1997, p. 117-126.

${ }^{149}$ A Espanha firmara em 1814 um acordo de aliança com a Grã-Bretanha, também se alinhando à política da potência hegemônica mundial.
} 
Em meio às negociações em Viena, a questão do tráfico de escravos voltou à pauta. Neste ponto, os interesses dos governos português e espanhol convergiam, afinal a escravidão representava parcela dominante da mão-de-obra na América. Organizaram-se em torno da necessidade de frear a campanha britânica contra o tráfico de escravos, alcançando relativo êxito, pois nos acordos mais gerais do Congresso, nada ficou decidido sobre a extinção do tráfico, e por meio de acordos circunscritos, a definição de tal tema ficou adiada para o futuro. Por intervenção britânica, a Santa Aliança não interferiria nos assuntos relativos à América espanhola, demonstração clara de que as atenções da Grã-Bretanha continuavam atentamente voltadas para o Novo Mundo. ${ }^{150}$ Quanto a Portugal, aprovou-se a abolição do comércio de escravos no hemisfério norte, retirando-lhe uma fonte abundante de escravos provenientes das regiões setentrionais da África, mas não era o suficiente para estabelecer o fim definitivo do tráfico. Dom João se viu obrigado a concordar com a abolição do tráfico ao norte do Equador, mas a realidade interna do reino - de total dependência econômica da mão-de-obra escrava -, estabelecia uma imensa distância entre os acordos internacionais e a prática. ${ }^{151}$

A convergência de interesses entre os governos ibéricos tinha limitações estabelecidas principalmente pela instabilidade do quadro político americano. O conde de Palmela, representante português em Viena, foi censurado pelo ministro de Negócios Estrangeiros e Guerra, o marquês de Aguiar, pela iniciativa do estabelecimento de uma ampla aliança entre Portugal e Espanha. Entre outros motivos, o ministro alegava que a ligação com a Espanha trazia o risco de envolver o

\footnotetext{
${ }^{150}$ PIMENTA, João Paulo Garrido. O Brasil e a América Espanhola (1808-1822), op. cit., p. 167.

${ }^{151}$ MARQUESE, Rafael de Bivar. Administração e escravidão. São Paulo: Hucitec, 1999.
} 
governo português na "guerra duradoura e renhida" que se travava na América hispânica. $^{152}$

As redefinições da política europeia, marcadas pelo caráter conservador e reacionário do Congresso de Viena influenciaram, muito rapidamente, o mundo iberoamericano. Já em maio de 1814, Fernando VII, de volta ao trono de Espanha, conseguia extinguir as Cortes e anular a Constituição, revestindo-se novamente do poder absoluto. A partir de então, a causa espanhola na América era a da restauração do poder metropolitano. ${ }^{153}$ Entretanto, a experiência dos seis anos anteriores promoveu a acentuação das contradições entre a política metropolitana e os interesses americanos, a ponto de promover a mutação definitiva dos movimentos iniciais, organizados em torno de ideais restauradores, para iniciativas de independência. Com exceção da região do Prata, o governo espanhol conseguiria um recuo significativo dos movimentos americanos pró-independência nos anos de 1815 e $1816^{154}$

A Venezuela, pela primazia e proporções da guerra pró-independência, era território prioritário para ações restauradoras da monarquia espanhola. Em fevereiro de 1815 , uma expedição numerosa e bem equipada, com mais de 10.000 homens, ${ }^{155}$ sob o comando de Pablo Morillo, foi enviada à América com o intuito de reintegrar suas antigas colônias ao domínio de Espanha. As forças de Morillo subjugaram temporariamente Venezuela e Nova Granada.

$\mathrm{Na}$ ausência de qualquer instituição que sustentasse um centro orientador, a luta pela causa republicana ficou a cargo de pequenos grupos que realizavam esforços irregulares de guerra. No final de 1814 e início de 1815, no leste da Venezuela,

\footnotetext{
${ }^{152}$ Despacho de Aguiar para Palmela, de 4 de março de 1816. Citado por ALEXANDRE, Valentim, $o p$. cit., p. 333-335.

${ }^{153}$ FONTANA, Josep. La crisis del antiguo régimen (1808-1833). 4.aed., Barcelona: Grijalbo, 1992; HALPERIN DONGHI, Tulio, op. cit., p. 150-153.

${ }^{154}$ PIMENTA, João Paulo Garrido. O Brasil e a América Espanhola (1808-1822), op. cit., p. 150-156; HALPERIN DONGHI, Túlio, op. cit., p. 150-187.

${ }^{155}$ SALCEDO-BASTARDO, José Luis. Historia fundamental de Venezuela, op. cit., p. 246.
} 
multiplicavam-se forças de resistência aos exércitos realistas formadas por corpos livres de fugitivos que se uniam a antigos soldados - a razão não era unicamente ideológica, pois muitos lutavam pelo desejo de escapar da morte certa. $\mathrm{Na}$ parte ocidental do país, a causa independentista era defendida por grupos provenientes do exército granadino sob o comando de José Antonio Páez como grande comandante militar. $^{156}$

Dessa maneira, a guerra entre os anos de 1815 a 1817 foi caracterizada pela fragmentação das forças que constituíam corpos militares, debilmente politizados e sem centro definido, criando condições para o surgimento de líderes militares com grande autonomia que definiram novas hierarquias civis e militares segundo lógicas não-institucionalizadas. ${ }^{157}$

Enquanto isso, Bolívar, de volta a Cartagena desde setembro de 1814, na impossibilidade de retorno ao território venezuelano, decide embarcar para um exílio voluntário na Jamaica, em maio de 1815 , onde permanece sete meses. ${ }^{158}$ Em

\footnotetext{
156 José Antonio Páez era natural de Acarigua, Venezuela. Nascido em uma família modesta, em 13 de junho de 1790, seu pai era empregado do governo espanhol no estanco de tabaco de Guanare. Aos 17 anos, acusado de um assassinato que alegava ter cometido em legítima defesa, refugia-se nas planícies da província de Barinas - nos llanos - trabalhando para Manuel Antonio Pulido. Ao final de 1810 integrou o corpo de cavalaria formado por ordem de seu patrão para lutar contra o governo criado em Caracas em 19 de abril. No ano de 1813 , com a patente de primeiro sargento, aderiu à causa independentista. Em janeiro de 1814 se uniu às forças comandadas por Ramón García de Sena, em Barinas. Em 18 de fevereiro, sob ordens de Antonio Rangel, participou da vitória contra as forças realistas comandadas por Aniceto Matute. No mês de setembro do mesmo ano, juntou-se às colunas chefiadas por Rafael Urdaneta. A derrota imposta pelas forças de Morillo o leva ao exílio na Colômbia, onde ao final de 1814 uniu-se a vários oficiais formando um corpo de cavalaria. Inicialmente, sob o comando de Antonio Figueredo, em pouco tempo, ascende como líder do grupo e ganha autonomia. Entre os anos de 1816 e 1817 Páez consolidou-se como chefe supremo do exército dos llaneros, tornando-se um dos maiores expoentes da causa republicana no período. Em 10 de maio de 1821, as forças comandadas por Páez saíram de Achaguas para unir-se a Bolívar na Batalha de Carabobo, em 24 de junho - batalha que selaria a independência da Venezuela. PÁEZ, José Antonio. Autobiografia. Nova Iorque: H. R. Elliot, 1945 (1867); THIBAUD, Clément. Repúblicas en armas, op. cit., p. 276282; Campaña de Carabobo. In.: Diccionario Multimedia de Historia de Venezuela. Fundación Polar: Caracas, 1995.

${ }^{157}$ THIBAUD, Clément. Repúblicas en armas. Op. cit., p. 261-309.

${ }^{158}$ Em 6 de setembro de 1815, publica a célebre "Carta da Jamaica". Em resposta a uma missiva de Henry Cullen - inglês radicado naquela Ilha -, Bolívar avaliou os fracassos preliminares dos processos de independência da América espanhola e afirmou a certeza da vitória da causa revolucionaria. Sentenciou: "el destino de América se ha fijado irrevocablemente: el lazo que la unía a España está cortado(...)." Contudo, assinalou a incerteza do futuro independente: "Todavía, es más difícil presentir la suerte futura del Nuevo Mundo, establecer principios sobre su política, y casi profetizar la naturaleza
} 
dezembro de 1815, chegou ao Haiti, onde viviam exilados muitos oficiais venezuelanos. A experiência haitiana (1791-1804) que ainda era exemplo de horror para muitos - o fim de uma sociedade escravista a partir da rebelião da população negra -, era constantemente evocada tanto pelos partidários do Antigo Regime na América hispânica, quanto por setores independentistas - para que tais excessos fossem evitados. ${ }^{159}$ Ademais, era exemplo de um movimento vitorioso de rompimento com o poder metropolitano, e, sobretudo, o refúgio e o apoio do governo haitiano interessado na instauração de governos americanos menos hostis à "República dos Negros" - eram indispensáveis. Simón Bolívar conseguiu recursos para uma nova expedição. Alcançou o território venezuelano em Margarita, no mês de maio de 1816 e, na sequência, conseguiu seu reconhecimento como "Chefe Supremos da República" por parte de uma assembleia de notáveis - reunião de oficiais exilados. Isso lhe deu a base necessária para iniciar a terceira e última fase pela concretização do projeto da República da Venezuela. ${ }^{160}$

No plano externo, a situação na Europa ao final do período napoleônico repercutiu diretamente nos negócios americanos. Sem os inconvenientes da guerra, a política britânica volta seus interesses para os territórios hispano-americanos, que ofereciam maiores possibilidades para expansão do seu comércio do que as relações com a Espanha. Produtos como cacau, café, frutos e couro, muito apreciados, foram

del gobierno que llegará a adoptar. Toda idea relativa al porvenir de este país me parece aventurada. ¿Se puede prever cuando el género humano se hallaba en su infancia rodeado de tanta incertidumbre, ignorancia y error, cuál sería el régimen que abrazaría para su conservación?" Analisou as insuficiências político-militares do movimento revolucionário na Venezuela, atribuindo-as à herança colonial que não ofereceu lição válida de organização e ação pública. Neste documento, também reconheceu a impossibilidade de realização de uma América unida por um único governo: "Es una idea grandiosa pretender formar de todo el mundo nuevo una sola nación con un solo vínculo que ligue sus partes entre si y con el todo. Ya que tiene un origen, una lengua, unas costumbres y una religión debería por consiguiente tener un solo gobierno que confederase los diferentes estados que hayan de formarse; mas no es posible porque climas remotos, situaciones diversas, intereses opuestos, caracteres desemejantes dividen a América." Cartas del Libertador, tomo I (1799-1817), 2a edição. Caracas: Banco de Venezuela/Fundación Vicente Lecuna, 1964, p. 215-235.

${ }^{159}$ HALPERIN DONGHI, Tulio, op. cit., p. 176.

160 THIBAUD, Clément. Repúblicas en armas, op. cit., p. 297. 
objetos de barganha nas Antilhas, onde se reanimou a guerra. Assim, para as forças republicanas, melhoraram progressivamente as condições de obtenção de armas e suprimentos. Agora, já não contavam somente com os que capturavam em suas vitórias e, já não eram, como antes, explorados pelos especuladores e traficantes que aproveitavam a ocasião para exercer práticas abusivas. ${ }^{161}$

A pacificação peninsular também impôs a necessidade de redefinições ao Império português. No tocante às suas relações com a América hispânica, o reforço do absolutismo espanhol na Europa indicava uma tendência à restauração dos princípios legitimistas na América - bastante interessante para o governo lusitano -, mas também implicava em “uma contração de parte importante da política externa joanina, agora parcialmente condicionada por um fortalecimento da Espanha e pela demonstração prática de sua capacidade de intervenção militar no continente americano". ${ }^{162}$

Quanto às demandas internas do reino, as pressões pelo retorno do rei à antiga sede do reino se tornaram crescentes. Com o final do conflito no continente europeu, em princípio, não haveria mais motivos para permanência da Corte portuguesa no Brasil. Porém, a monarquia portuguesa em crise, para garantir a unidade de seu império, mais do que nunca, precisava criar condições para sua manutenção em território americano. Em sentido contrário à pressão peninsular, os esforços da Coroa pareciam voltados a equipar sua nova capital a fim de torná-la permanente. Respondendo à coligação de forças que praticamente exigia o seu retorno a Portugal, dom João elevou o Brasil a condição de Reino Unido em 16 de dezembro de 1815, legitimando o Rio de Janeiro como sede da monarquia portuguesa. ${ }^{163}$ Assim, além de

\footnotetext{
${ }^{161}$ SALCEDO-BASTARDO, José Luis, op. cit., p. 248.

${ }^{162}$ PIMENTA, João Paulo Garrido. O Brasil e a América Espanhola (1808-1822), op. cit., p. 149.

${ }^{163}$ LIMA, Oliveira. Dom João VI no Brasil 1808-1821, op. cit., cap. XIII, p. 335-356; SCHWARCZ, Lilia Katri Moritz. A Longa Viagem da Biblioteca dos Reis: do terremoto de Lisboa à Independência do
} 
neutralizar as tensões causadas pelas pressões em torno do regresso do rei a Lisboa, a elevação do Brasil a reino serviu para a afirmação de sua integridade territorial, buscando evitar o exemplo da vizinhança hispânica.

Neste sentido, no início de 1816, o governo lusitano reacendeu a questão platina investindo contra o território hispânico de Maldonado, Colônia do Sacramento e Montevidéu. O projeto de anexação, do lado Oriental do Prata, prolongar-se-ia até os finais da década de $1820 .{ }^{164}$ Ainda no ano de 1816 , faleceu a rainha dona Maria I, consequentemente, o príncipe regente, que na prática já respondia pela política portuguesa, teria agora o seu reinado formalizado. ${ }^{165}$

Entretanto, o saldo da criação do Reino Unido não era essencialmente positivo para a monarquia portuguesa. Os esforços pela unidade do reino evidenciaram e aprofundaram, ainda mais, suas contradições internas. As cisões entre as partes do Estado português - já aumentadas desde 1808, quando o Rio de Janeiro passou a contar com várias das mesmas instituições que vigoravam em Lisboa ${ }^{166}$-, tornaramse cada vez mais evidentes. No Brasil, o estabelecimento da sede do Império alimentava o ideário relacionado ao fim da condição colonial e, do outro lado do Atlântico, a porção europeia do reino se ressentia pela ausência do soberano e o sentimento de redução, provocado pela inversão do eixo organizador do Império. Na previsão do diplomata português, Silvestre Pinheiro Ferreira - em 1815 -, o Príncipe

Brasil. São Paulo: Cia das Letras, 2002, p. 301-315; PIMENTA, João Paulo Garrido. O Brasil e a América Espanhola (1808-1822), op. cit., p. 186-190; ARAÚJO, Ana Cristina. Um Império, um Reino e uma Monarquia na América: as vésperas da Independência do Brasil. In.: JANCSÓ, István (org.). Independência: História e historiografia. São Paulo: Hucitec, 2005, p. 262-170.

${ }^{164}$ A partir de 1820, com o início da revolução liberal em Espanha - golpe decisivo nos planos de Madri para intervir militarmente no Prata - a questão platina se altera progressivamente para um conflito restrito à dimensão americana. ALEXANDRE, Valentim, op. cit., p. 338-373.

${ }^{165}$ Contudo, a planejada aclamação de dom João foi adiada pelo movimento de contestação ao governo português iniciado em Pernambuco, no dia 6 de março de 1817, do qual trataremos mais adiante. A coroação de dom João VI, Rei do Reino Unido de Portugal, Brasil e Algarves, ocorreria onze meses depois, em fevereiro de 1818.

${ }^{166}$ SLEMIAN, Andréa e PIMENTA, João Paulo Garrido. O nascimento político do Brasil. As origens do Estado e da Nação (1808-1825). São Paulo: DPA\&A Editora, 2003. 
Regente, D. João, “enfrentava então um duplo dilema: o da emancipação das colônias, no caso de (...) regressar à Europa"; e o "da insurreição do Reino de Portugal, se aqueles povos, perdida a esperança que ainda os anima de tornarem a ver o seu amado príncipe, se julgarem reduzidos à humilhante qualidade de colônia". ${ }^{167}$

O debate em torno da sede do governo dividiu opiniões e configurou um gradativo antagonismo de posições no universo político português, cujo último desdobramento conduziria à independência do Brasil. Conforme assinalado por Ana Cristina de Araújo, a “cisão da casa reinante de Bragança, dividida entre dois Estados com a mesma chancelaria, a institucionalização do Reino Unido substancia, no plano simbólico, a decadência de um sistema imperial e a fraqueza política de um regime". 168

O sentimento de instabilidade da monarquia portuguesa em território americano foi severamente agravado pelos acontecimentos de 1817 em Pernambuco. Os tão temidos ecos dos movimentos hispano-americanos se fizeram sentir dentro dos domínios portugueses. Mesmo sufocado pelo governo lusitano, o movimento pernambucano comprovou que os receios de convulsão na América portuguesa, não eram apenas invenções estimuladas pela observação da turbulência nos domínios espanhóis na América. ${ }^{169}$ Tanto assim que teriam impacto também na América espanhola, como nos mostra o Correo del Orinoco.

\footnotetext{
${ }^{167}$ Documentos para História da Independência, vol.1. Rio de Janeiro: Biblioteca Nacional, 1923, p. 129. Citado por ARAÚJO, Ana Cristina. Um Império, um Reino e uma Monarquia na América: as vésperas da Independência do Brasil, op. cit., p. 264.

${ }^{168}$ Ibdem

${ }^{169}$ PIMENTA, João Paulo Garrido. O Brasil e a América Espanhola (1808-1822), op. cit., p. 215-236.
} 


\section{CAPÍTULO 3: 1817}

\section{1- Esforços para o estabelecimento da República na Venezuela}

Em 1817, praticamente toda a América espanhola estava em convulsão. Nas palavras de Halperín Donghi, "a guerra é o que sobreviveu da Revolução" ${ }^{170}$ As forças realistas seguiram combatendo os movimentos de independência política, agora, não apenas como aspiração de alguns setores das sociedades americanas, mas como desenlace inevitável - e irreversível -, da crise do Antigo Regime naqueles territórios.

Como em quase todo o restante da América hispânica, na Venezuela, o período entre 1817-1820 foi caracterizado pela concretização de um projeto de independência que logo em seguida se mostraria vitorioso. Neste cenário, a província de Guayana representava um depósito de recursos materiais praticamente intacto. Até a vitória das forças republicanas na batalha de San Félix, em 11 abril de 1817, e a tomada de Angostura - atual Ciudad Bolívar - em junho sequente, Guayana tinha sido uma região mantida continuamente sob domínio realista, escapando ilesa da destruição provocada pela guerra que assolava o restante do país. Uma vez que o movimento republicano se firmara ali, não ocorreriam mais reveses de importância para a conclusão do processo de Independência. ${ }^{171}$

Por sua localização estratégica - facilidade de comunicação e deslocamento pelo rio Orinoco -, Angostura tornou-se a base geopolítica do movimento de independência da Venezuela, garantindo uma relativa segurança material e psicológica, necessária não só para guerra, como também para a constituição das

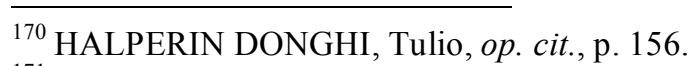

${ }^{171}$ SALCEDO-BASTARDO. José Luis, op. cit., p. 249-251.
} 
bases legais de um governo centralizado. Nas palavras de Simón Bolívar em carta dirigida ao general Francisco Rodríguez:

"Por fin tenemos a Guayana libre e independiente. (...) Esta provincia es un punto capital; muy proprio para ser defendido y más aun para ofender: tomamos la espalda al enemigo desde aquí hasta Santa Fé y poseemos un inmenso territorio en una y otra ribera del Orinoco, Apure, Meta y Arauca. Además poseemos ganados y caballos". 172

Na mesma data, a Fernando Peñalver, concluía que:

"La ocupación de las plazas de Guayana y del Orinoco por nosotros, facilita extraordinariamente las empresas de los comerciantes que quieran introducirnos estos elementos: aquí serán satisfechos en ganados, mulas o en los frutos del país. La navegación está expedita y segura; nada hay que temer de los enemigos(...)". ${ }^{173}$

No dia seguinte, em carta para o coronel Leandro Palácios, Bolívar assinalou a situação privilegiada de Guayana em relação ao restante do país, e a importância de sua conquista para a causa independentista:

“¡Al fin tengo el gusto de ver libre a Guayana! (...) El país no ha quedado en el mejor estado, por lo que casi se ha aniquilado en los

\footnotetext{
${ }^{172}$ Carta de Simón Bolívar ao General Francisco Rodríguez, Marquês del Toro. Guayana, 06 de agosto de 1817. In.: Cartas del Libertador, tomo I (1799-1817), $2^{\mathrm{a}}$ edição. Caracas: Banco de Venezuela/Fundación Vicente Lecuna, 1964, p. 403.

${ }^{173}$ Carta de Simón Bolívar a Fernando Peñalver. Guayana, 06 de agosto de 1817. In.: Cartas del Libertador, op. cit., p. 406.
} 
siete meses de sitio, y porque una gran parte de la gente emigró con los españoles. (...)

Hemos encontrado las plazas bien guarnecidas de artillería, algunos almacenes de vestidos, municiones, fusiles $\mathrm{y}$ otros efectos interesantes. Yo creo que este suceso acabará de ganarnos la opinión de los extranjeros y de decidir a los venezolanos que han quedado aún en esas colonias, para venirse a su país a trabajar por la libertad". ${ }^{174}$

Contudo, a vitória do movimento republicano ainda não era nítida aos olhos de seus protagonistas. Após a conquista de Angostura, as forças pró-independência eram um conjunto heterogêneo de corpos dispersos por todo território da Venezuela, que seguiam empreendendo esforços irregulares de guerra, como reconhece o próprio Bolívar em carta ao comandante Tovar Ponte:

"Ya es tiempo de que te vengas, a ver si la patria recobra sus hijos dispersos, y para que veas que, las circunstancias, no son las mismas que el 19 de abril; entonces el derecho tenía algún valor, pero ahora la fuerza y la maña es la que manda, y eso con mucha dificultad, porque nuestras guerrillas son verdaderamente independientes $(\ldots){ }^{\prime \prime}{ }^{175}$

\footnotetext{
${ }^{174}$ Carta de Simón Bolívar ao coronel Leandro Palacios. Guayana, 07 de agosto de 1817. In.: Cartas del Libertador, op. cit., p. 407.

${ }^{175}$ Carta de Simón Bolívar a Martín Tovar Ponte. Guayana, 06 de agosto de 1817. In.: Cartas del Libertador, op. cit., p. 405.
} 
Constituir um governo centralizado de fato, e não só simbólico, era fundamental à causa. Assim, a organização interna da República representava uma empreitada tão árdua quanto o combate contra as forças realistas.

As diferenças e contradições internas tornaram-se mais agudas nesta fase de institucionalização do governo em sua nova sede. O caso de Manuel Piar, o general responsável pela vitória na batalha de San Félix, descrita por Bolívar como "o mais brilhante sucesso que alcançaram as nossas forças na Venezuela", ${ }^{176}$ é excelente exemplo das dificuldades da administração da república armada neste período. ${ }^{177} \mathrm{Em}$ junho de 1817 o "Chefe Supremo da Venezuela" lhe escreveu:

\footnotetext{
"General, prefiero un combate con los españoles a estos disgustos entre los patriotas. Vd. sí que está prevenido contra sus compañeros, que debe saber que son sus amigos, y de quien no debe separarse para el mejor servicio de la causa. Lo contrario es servir a lado de la opresión.
}

Sí, sí nos dividimos, sí nos anarquizamos, sí nos destrozamos mutuamente, aclararemos las filas republicanas, haremos fuertes las

\footnotetext{
${ }^{176}$ Carta de Simón Bolívar ao coronel Leandro Palacios. La Mesa de Angostura, 16 de maio de 1817. Ibdem, p. 365. Manuel Piar era natural da Ilha de Curaçao, filho de María Isabel, uma mulata holandesa, e de Fernando Piar, marinheiro espanhol. Chegou à Venezuela com sua mãe quando tinha aproximadamente dez anos. Fixou residência em La Guaira, onde aos 23 anos participou da chamada conspiração de Gual e España, em meados de 1797. Em janeiro de 1807 foi para o Haiti integrando as forças revolucionárias da Ilha. De volta à Venezuela, uniu-se ao movimento de independência participando da Batalha de Sorondo no rio Orinoco, em 1812. Traçou carreira militar notável junto às forças independentistas. Após sua vitória em San Félix, em abril de 1817, foi promovido ao posto de general em chefe. TOUR, Antonio Octavio. Biografía del general Manuel Carlos Piar. Caracas: Venevasco, 1985.

${ }^{177}$ THIBAUD também utiliza a expressão governo militar, pois neste período a república e o exército eram entidades intercambiáveis: THIBAUD, Clément. La Administración de La República Armada. In.: República en armas. Los ejércitos bolivarianos en la guerra de Independencia en Colombia y Venezuela. Bogotá: Planeta, 2003, p. 317 -332.
} 
de los godos, triunfará España y con razón nos titularán vagabundos". 178

Semanas depois, um atentado contra Bolívar na laguna de Casacoima província de Guayana - só aumentaria as tensões. Piar fora acusado de insubordinação ao governo, deserção e conspiração contra a ordem social. Contudo, pouco mais de dois meses antes de seu julgamento oficial, já estava condenado pelo movimento republicano, como se pode verificar na proclamação de Simón Bolívar no início do mês de agosto:

"Sí, Venezolanos, el General Piar ha formado una conjuración destructora del sistema de igualdad, libertad y independencia. (...)

Calumniar al gobierno de pretender cambiar la forma republicana en la tiranía; proclamar los principios odiosos de la guerra de colores para destruir así la igualdad que desde el día glorioso de nuestra insurrección hasta el momento ha sido base fundamental. Instigar a la guerra civil, convidar a la anarquía, aconsejar al asesinato, el robo y el desorden, es en sustancia lo que ha hecho Piar desde que obtuvo la licencia de retirarse del ejercito, que con tantas instancias había solicitado, por que los medios estuvieran a su alcance". ${ }^{179}$

O General Manuel Piar foi julgado e condenado à pena capital pelo conselho de guerra, presidido por Luis Brión, em 15 de outubro daquele mesmo ano. A sentença foi executada no dia seguinte por fuzilamento. As acusações contra Piar, não

\footnotetext{
${ }^{178}$ Carta de Simón Bolívar ao General Manuel Piar. San Félix, 19 de junho de 1817. In.: Cartas del Libertador, op. cit., p. 381

${ }^{179}$ Simón Bolivar jefe Supremo de la República de Venezuela. Cuartel General de Guayana, 5 de agosto de 1817. In.: http://www.simon-bolivar.org
} 
comprovadas documentalmente no processo, ${ }^{180}$ evidenciam as principais dificuldades da unificação do movimento republicano em torno de um governo centralizado e institucionalizado.

A primeira acusação, de que o general pardo teria a ambição de sublevar pardos contra os brancos, conspirando, assim, contra a ordem e tranquilidade pública, é bastante significativa quanto à questão racial. Fernando Galindo, em defesa do réu argumentou:

“El general Manuel Piar es el más loco de los hombres, o él no ha intentado tal conspiración. O él perdió el juicio en aquellos días, o no hizo más que prorrumpir indiscretamente contra los que se imaginaba le querían sacrificar. Nada apoya más esta razón que la pretendida indignación contra los mantuanos, que es el fundamento y origen de toda esta causa. Esta es una clase de hombres que desde 19 de abril se extinguió junto con la tiranía, y a nadie todavía en Venezuela le ha ocurrido un pretexto semejante para revolucionar". ${ }^{181}$

Assim, a questão da desigualdade racial e a tirania - termo recorrente nos discursos usado para assinalar todo e qualquer tipo de situação que possa ser considerada injusta - seriam os principias motivos para "revolucionar", ou seja, sublevar a ordem estabelecida. Como estas questões teriam sido sanadas com a quebra do vínculo com o poder metropolitano através da proclamação de 19 de abril de 1810

\footnotetext{
${ }^{180}$ O julgamento do General Manuel Piar está disponível In.: http://www.simon-bolivar.org/principal/bolivar/juicio_a_piar.html

Defensa de S. E. El Señor General Manuel Piar, acusado de insubordinado a la suprema autoridad, de conspirador contra el orden y tranquilidad pública y, últimamente, de desertor y sedicioso. Cuartel General de Angostura, 15 de outubro de 1817.

In.: http://www.simon-bolivar.org/principal/bolivar/juicio_a_piar.html
} 
- pelo menos na esfera dos discursos -, não havia mais motivos para questionamentos. Na prática, a questão racial ainda estava distante de uma solução. ${ }^{182}$

No mesmo período, a fragmentação e autonomia das diversas forças próindependência tornavam quase todos os chefes militares suscetíveis à acusação de insubordinação contra o governo republicano. Bermúdez, Mariño e seus aliados haviam organizado um congresso com o objetivo de definir o direcionamento da guerra independente de Bolívar; José Antonio Páez comandava com completa autonomia as forças entre Arauca e Apure; somente Monagas estava totalmente submetido às ordens do "Libertador". ${ }^{183}$ Por que apenas o general Piar foi acusado formalmente, submetido a julgamento e condenação máxima? A origem parda de Manuel Piar, e sua experiência no processo haitiano, sem dúvida, aterrorizavam os demais comandantes militares temerosos da possibilidade de insubordinação de suas tropas. ${ }^{184}$ Segundo Clément Thibaud, Piar cristalizava todos os temores de uns, os 'brancos', e as esperanças de outros, os 'pardos'. ${ }^{185}$ Sua condenação amenizaria consideravelmente os temores de uma revolta popular ou escrava no seio da República e, ao mesmo tempo, reafirmaria a autoridade do pretendido poder central.

Sobre a acusação de insubordinação à autoridade suprema, a defesa de Piar argumentou:

"Comencemos por establecer la diferencia que hay entre
insubordinación y temor. Aquella es un acto escandaloso de

${ }^{182}$ GÓMEZ, Alejandro E.. Del affaire de los mulatos al asunto de los pardos. In.: CALDERÓN, Maria Teresa; THIMBAUD, Clément (org.). Las Revoluciones en el mundo atlántico. Bogotá: Universidad Externado de Colombia, Tauros Historia, 2006, p. 301-321; Idem. The 'Pardo Question'. In.: Revista digital Nuevo Mundo Mundos, Nuevos Materiales de seminarios, de 15 de setembro de 2008. http://nuevomundo.revues.org/index34503.html

${ }_{183}^{183}$ THIBAUD, Clément. República en armas, op. cit., p. 317.

${ }^{184}$ GÓMEZ, Alejandro E.. La Revolución Haitiana y la Tierra Firme hispana. In.: Revista digital Nuevo Mundo Mundos Nuevos, Debates 2005, de 17 de fevereiro de 2006. http://nuevomundo.revues.org/index211.html

${ }^{185}$ THIBAUD, Clément. República en armas, op. cit., p. 318. 
desobedecimiento y de resolución; este es un miedo mezclado de confianza y de respeto mismo a la autoridad, que impele a cometer errores involuntarios. (...) Tal es el estado en que desgraciadamente se encontraba aquél cuando recibió la intimación del general Bermúdez, comunicada por su edecán Machado, para marchar a presentarse al Supremo Jefe al Cuartel general de Casacoima. Rodeado por muchas partes de enemigos particulares, advertido de que se le perseguía por los mismos que más le habían apreciado; asestado por émulos o enemigos secretos; instruido falsamente por amigos suyos, residentes en el Cuartel General, que se proyectaba su sacrificio; (...)se creyó perdido, y se vio fuera de sí, cuando le ordenó la ida a Casacoima".

Elencando os inimigos de Manuel Piar:

“(...). El Coronel Francisco Sánchez emprendió allí el repase de nuestro ejército a Barcelona: y sin la firme resolución del general Piar y de otros jefes justos y constantes no poseeríamos tranquilamente hoy a Guayana. Sánchez fue despedido, como es notorio, del ejército del general Piar, y desde entonces el juro venganza. (...)

Son también sus enemigos el coronel Pedro Hernández y el teniente coronel Olivares: el primero, porque en la acción de San Félix fue fuerte y públicamente reprendido por él, declarándose aquél desde entonces en su contra; y el segundo, por el suceso de Upata con el 
subteniente Arias, en el que Piar le echó toda la culpa a Olivares, y este acabó por no ser más su amigo". ${ }^{186}$

Assim, os argumentos tratam de conspirações, rivalidades internas, indícios significativos da instabilidade e fragmentação do movimento republicano neste momento. Outro elemento importante a ser considerado é a liderança regional e força militar que tinha Manuel Piar. Citando mais uma vez a defesa do general:

“Cómo es que en el primer documento se atreve a llamar serpiente y monstruo de la República al que más ha contribuido a regenerarla, al libertador del oriente, al héroe de Maturín, al afortunado en los Corocillos al espanto de los españoles en Cumanacoa, al que con su nombre y su audacia sola fue triunfador en el Juncal, al que pulverizó en San Félix las huestes arrogantes de Morillo y al que nunca ha sido vencido entre los generales de Venezuela?"187

Segundo Thibaud, "ao concentrar-se no general pardo de origem estrangeira, Bolívar não buscava rebaixar o poder dos caudillos, senão eliminar um terrível rival que compartilhava sua ambição "reguladora'."188 De qualquer maneira, o caso do general Piar no contexto dos esforços de instituição formal do governo republicano é significativo, pois em último caso, representou um esforço na fixação de limites à autonomia de cada força que realizava a guerra territorial. A utilidade da condenação do general Piar pode ser resumida nas seguintes palavras de Bolívar dirigidas ao general Bermúdez:

\footnotetext{
${ }^{186}$ Defensa de S. E. El Señor General Manuel Piar. Documento citado.

${ }^{187} \mathrm{Ibdem}$

${ }^{188}$ THIBAUD, Clément. República en armas, op. cit., p. 318.
} 
“(...) que Vd. marche a Maturín, y que volando se encargue del mando de la provincia de Cumaná, en donde acabará de conjurar los elementos de sedición y de guerra civil, obras como vd. sabe del general Piar. (...)

Sofocada la sedición, sometidos o castigados de alguna manera los culpables, la vindicta pública estará satisfecha; se vigorizarán la disciplina y obediencia del ejército; nuestros enemigos del extranjero no tacharán nuestra obra de falta de autoridad; y los malvados godos, se encontrarán sin base para calumniarnos; no dirán que somos una horda de vagabundos." 189

Contudo e apesar da impossibilidade de organização plena de um regime representativo, sob ordens de Simón Bolívar, estabeleceram-se em Angostura, no ano de 1817, os fundamentos institucionais da nova República, procurando substituir a imagem de fragmentação por um sentido de ordem e juridicidade. Na impossibilidade da representação do povo, foram estabelecidos instrumentos de governo legitimados pela guerra e pelas necessidades de combate. O momento de "tão extraordinários, tão rápidos e impetuosos movimentos de guerra", exigia um governo forte e militar. Assim foi justificada a criação do Conselho de Estado que junto ao presidente, Simón Bolívar, concentravam os poderes do governo. ${ }^{190}$ Além deste Conselho de Estado, instituiu-se a Alta Corte de Justiça, incumbida da difícil tarefa de fazer respeitar os direitos dos cidadãos contra qualquer arbitrariedade de "chefe civil ou militar". ${ }^{191}$

\footnotetext{
${ }^{189}$ Carta de Simón Bolívar ao general José Francisco Bermúdez. Angostura, 04 de outubro de 1817. In.: Cartas del Libertador, op. cit., p. 426.

${ }_{190}$ Acta de instalación del Consejo de Estado en Angostura, 10 de novembro de 1817. Citada por THIBAUD, Clément. República en armas, op. cit., p. 319-320.

${ }^{191}$ Ibdem, p. 321.
} 
Dessa forma, a institucionalização de 1817 buscava dirigir o país rumo ao fim da guerra civil ao regularizar a gestão dos conflitos.

No momento em que em que foram lançadas as bases para as instituições centrais, Bolívar definiu espaços de domínio dos caudillos nas regiões de combate. Estas circunscrições correspondiam às zonas de influências dos chefes militares já estabelecidas. Podemos citar, por exemplo, a nomeação de Monaguas para governador e comandante geral da província de Barcelona - da parte sobre influência republicana, pois a capital ainda estava sob domínio realista; e de Bermúdez, para a província de Cumaná. Cada governador - comandante possuía sua guarda de honra, elemento essencial de sua influência. ${ }^{192}$

Assim, a fragmentação das tropas republicanas era evidenciada territorialmente, pois foram constituídas três zonas de influências independentes uma das outras: a do ocidente, comandada por Páez; a do centro, por Bolívar; e a do oriente, mais indefinida e conflituosa, Arizmendi, Bermúdez e Mariño disputavam a supremacia. Nestas aéreas muitas guerrilhas coexistiam com os corpos regulares em constituição. Por decreto de 24 de setembro de 1817, foi instituído um estado geral maior para organização e direção dos exércitos. Bolívar, como presidente, desempenhava o papel de mediador entre os grupos guerreiros já constituídos, o que lhe possibilitava a manutenção de sua condição de líder, pois que manejava os instrumentos legais que determinavam as relações de força. ${ }^{193}$

Junto aos demais esforços de institucionalização da República nesta terceira fase, foram estabelecidas diretrizes para a distribuição de terras contemplando a massa popular combatente e a liberdade para alistados no exército. Compreendeu-se que as vitórias realistas sobre as duas tentativas anteriores de instauração da

\footnotetext{
${ }^{192}$ Acta de instalación del Consejo de Estado en Angostura. Citada por THIBAUD, República en armas, op. cit., p. 321.

${ }^{193}$ THIBAUD, Clément. República en armas, op. cit., p. 321-322.
} 
República estavam relacionadas, direta ou indiretamente, à reação popular. ${ }^{194}$ Neste sentido, devemos considerar a adesão dos llaneros à causa independentista. O mesmo grupo que três anos antes garantiu a vitória realista sob comando de Boves, hostilizados pela política do novo governo espanhol, passaram a engrossar as linhas do movimento independentista sob o comando de Antonio Páez, que a partir de então, tornar-se-ia um dos maiores expoentes da causa republicana no período. O grupo comandado por Páez foi de capital importância para a empreitada republicana, inclusive em território granadino. ${ }^{195}$

Assim, no ano de 1817, a guerra pela independência tinha como um dos cenários mais dinâmicos o Sul da Venezuela. Guayana - província cujo território era contíguo ao da capitania luso-americana do Pará, norte do Brasil - estava ocupada militarmente pelas forças independentistas e, em Angostura, estabeleciam-se as bases do governo central republicano. Ao final daquele ano, o movimento pela independência da Venezuela já tinha assegurado suas posições em todo leste e sul do país. Em fevereiro do ano seguinte, os esforços independentistas seguiram vitoriosos no combate contra o exército do general espanhol Pablo Morillo em Calabozo, Província de Caracas - hoje parte do estado de Guarico - e ocuparam os vales de Aragua. ${ }^{196}$

Nesta fase, a luta pela independência tinha contornos de guerra civil, condição que obrigava não só indivíduos, mas comunidades inteiras a tomarem partido na guerra, pois sofriam diretamente suas consequências. Assim, a utilização da imprensa para propagação de rumores e para a difusão de uma imagem positiva dos resultados

\footnotetext{
${ }^{194}$ No discurso de Abertura do Congresso de Angostura, em 1819, Simon Bolívar propõe o fim absoluto da escravidão - como forma de afiançar a República -, mas a proposta foi rejeitada pela maioria dos deputados. Na República da Venezuela a abolição seria declarada somente em 23 de março de 1854.

${ }^{195}$ THIBAUD analisou os motivos da "virada dos llaneros" e fez um balanço historiográfico sobre a questão. República en armas, op. cit., p. 332-351.

${ }^{196}$ Mapas da divisão territorial da Venezuela no período e atual: anexos 2 e 3, respectivamente.
} 
das empreitadas republicanas, bem como dos seus ideais e propósitos, era arma tática fundamental no combate ao inimigo. Como assinalado pelo próprio Bolívar, a imprensa era "tan útil como los petrechos". ${ }^{197}$

Neste contexto, concebido como veículo oficial do governo da Terceira República da Venezuela, o Correo del Orinoco converteu-se em uma das principais armas do movimento republicano, com a missão de difundir a nova ordem que se queria estabelecer.

No cumprimento da tarefa de difundir uma imagem positiva das ações republicanas, a manipulação e a omissão de informações eram expediente frequentemente utilizado. "Na debilidade extrema em que se encontrava, Bolívar, não teve outra alternativa a não ser dissimular um exército que não possuía". ${ }^{198}$ Neste aspecto, o caso de Manuel Piar mais uma vez nos serve de exemplo, pois nas páginas do Correo del Orinoco, não se encontra uma linha sobre seu processo e julgamento. Apenas em agosto de 1818, quase um ano depois da execução do general pardo, devido a necessidade de propagar uma imagem coesa da República, o Correo del Orinoco publicou:

"Han llegado a nuestras manos las Gazetas de Caracas del 8, 15 y 22 de abril en que se insertan varias cartas del Gefe supremo al Secretario Brizeño, y las contestaciones de este relativas a los proyectos del General Piar. Estamos autorizados para asegurar al público que los documentos en cuestión, están alterados, trunados, $\mathrm{y}$ dislocados". 199

\footnotetext{
${ }^{197}$ Carta de Simón Bolívar a Fernando Peñalver. Guayana, $1^{\circ}$ de setembro de 1817. In.: Cartas del Libertador, op. cit., p. 412.

${ }^{198}$ THIBAUD, Clément. República en armas, op. cit., p. 328.

${ }^{199}$ Correo del Orinoco, n. ${ }^{\circ} 6,1^{\circ}$ de agosto de 1818, op. cit., p. 24.
} 
Sendo um dos elementos principais na estratégia de guerra, o periódico era responsável pela defesa do movimento republicano contra as ofensivas impressas veiculadas pela Gaceta de Caracas, que utilizava dos mesmos métodos pela causa contrária - exagerando, ocultando ou até mesmo forjando informações. ${ }^{200} \mathrm{O}$ Correo del Orinoco cumpria ainda uma função normativa, veiculando atas, leis, proclamas, informando a todos os venezuelanos sobre as definições da República, sendo assim instrumento importantíssimo também nos esforços de unificação e centralização do governo republicano.

Portanto, o Correo del Orinoco é fonte importantíssima em relação ao que se projetava para a República da Venezuela neste período.

Uma questão central com a qual a República da Venezuela teria que lidar era o desafio de definir um posicionamento em relação à vizinhança monarquista. A neutralidade do governo português em relação às guerras em território hispânico na América seria vital ao movimento republicano, que não tinha forças para combate em nova frente. Os registros conhecidos dos contatos entre a República da Venezuela e a América portuguesa ainda carecem de estudo aprofundado, mas nos permitem vislumbrar um conjunto de ações muito elucidativas da importância que eles tiveram para a configuração geral das lutas de independência.

Em de março de 1818, Joaquim José Vitorino da Costa, governador da capitania de São José do Rio Negro ${ }^{201}$ encaminhou junto a um relatório para o Conde de Vila Flor, capitão-geral do Grão-Pará, uma cópia “do ofício do novo comandante pelos rebeldes ali, Hipólito Cuevas, de 21 de dezembro" do ano anterior,

\footnotetext{
${ }^{200}$ ROSAS MARCANO, Jesús; SANOJA HERNÁNDEZ, Jesús; LIZARDO, Pedro F.. Papel de la Prensa en la Lucha por la Independência de Venezuela. In.: Bolívar y el periodismo, op. cit., p. 237245.

${ }^{201}$ Criada em 1755, era submetida ao Estado do Grão-Pará e Maranhão, abrangia território que hoje corresponde aos estados do Amazonas e Roraima.
} 
encaminhado ao comandante de fronteira no forte de São José de Marabitanas, ${ }^{202}$ o tenente Pedro Miguel Ferreira Barreto. O capitão Cuevas escrevia em nome do general José Antonio Páez, um dos principais chefes militares na guerra pela independência da Venezuela :

"El Ciud. Benemerito José Antonio Páez, del orden del Libertador, General de Brigda de los Ejércitos de la República y en nombre del que obra en el Bajo Apure y Llanos de Casanare y me ha destinado no atacar ni destruir los Pueblos de Alto Orinoco y Rio Negro si no a restituir a sus moradores su Libertad Civil y Política y el goce de sus naturales e inpresseptibles Drõs, pues así como la protección acordada por la sociedad a cada uno de sus miembros para la conservación de sus personas de sus Drõs y de sus propiedades; la gral de la República consiste en la identidad de opinión en los Pueblos que la componen.

No me detendré en cuestionar por menor acerca de la Justicia que le asiste a nuestra causa, por ser materia tratada larga y vulgarmente por muchos y graves A. A., solamente diré con el célebre D’ inglés Adam Smit que la Independencia de la América Española es un acontecimiento que está en el orden de la naturaleza.

No es nuestro ánimo declarar a nadie la guerra si no defendernos de la opreción y así este V., persuadido que nuestras tropas jamás llegarán a invadir los pueblos de su Guarniçon y a un que enemigos hacen de nosotros un retrato extraordinario puede V. creer que sus fronterizos instruidos ahora en sus derechos y

\footnotetext{
${ }^{202}$ O Forte de São José de Marabitanas localizava-se à margem direita do alto rio Negro, afluente da margem esquerda do rio Amazonas, cerca de quinze quilômetros abaixo de Cucuí, no atual Estado brasileiro do Amazonas - na região da tríplice fronteira entre o Brasil, a Colômbia e a Venezuela. Mapa: anexo 3.
} 
obligaciones podremos dezempeñar estas del modo debido y defender aquellos con el tinos que es proprio a unos hombres libres. La tranquilidad de que ahora desfrutamos protegida de 18000 hombres situados en las Provincias de Casanare, Barrinas, Caracas, Cumana, Barcelona y Guayana nos hace tener en sus puertos el más vivo comercio con todas las naciones principalmente por el Canal del Orinoco por cual nos ofrecemos por si V. quisiese de esta algún artículo de Comercio de esta última por el más pronto recurso ó de los naturales producimientos de los Pueblos de ella, de los que tal vez carecera por el lugar estéril de suposición. Dios Gue a V. muchos anõs, Sn. Fernando de Atabapo, 21 de deciembre de $1817-1^{\circ}$ de nuestra Independencia". ${ }^{203}$

Percebe-se o cuidado inicial do oficial da república venezuelana em declarar as intenções pacíficas de sua missão - "não atacar nem destruir" -, expressando a preocupação na "preservação das pessoas e suas propriedades" na região do alto Orinoco e Rio Negro. Apresentando o movimento republicano em termos amenos, a causa independentista da Venezuela foi inserida no contexto mais amplo da América espanhola, explicada como consequência natural e inevitável de um processo cíclico, "na ordem da natureza".

Mais diretamente sobre a posição em relação às possessões portuguesas na América, Hipólito Cuevas, por meio de seu ofício, além de destacar o fato de nunca ter existido nenhum tipo de ofensiva às fronteiras com a América portuguesa, oferece

\footnotetext{
${ }^{203}$ Ofício de Hipólito Cuevas para Pedro Miguel Ferreira Barreto, 21 de dezembro de 1817. Seção de manuscritos da Biblioteca e Arquivos Públicos do Estado do Pará. In.: FERREIRA REIS, Arthur Cézar, Neutralidade e boa vizinhança no início das relações entre brasileiros e venezuelanos documentário. In.: Revista do Instituto Histórico e Geográfico Brasileiro, vol. 235, abril-junho de 1957, p. 39. Também citado parcialmente por THIBAUD, Clément. República en armas, op. cit., p. 330 (AGI, Caracas, leg 71, doc 18). THIBAUD aponta Antonio Páez como autor do ofício.
} 
a possibilidade do estabelecimento de relações comerciais garantidas pela “tranquilidade do Orinoco". Contudo, por precaução, de forma muito discreta, assinala o poder de defesa do movimento republicano citando um contingente intimidador, de 18000 mil homens. Sabemos que tal número era improvável, pois como visto, os esforços republicanos ainda não estavam totalmente organizados em torno de um poder centralizado, pelo contrário, encontravam-se ainda fragmentados, muito desgastados pelos anos de guerra, quase sem recursos - situação que vinha sendo revertida, aos poucos com a tomada de Angostura. Portanto, a utilização de tal número, provavelmente, era tática retórica, mas o uso de tal expediente evidencia a necessidade de conseguir a manutenção da neutralidade do governo português na América em relação à guerra na vizinhança hispânica - mesmo que à base de intimidações.

Assim, percebe-se que a neutralidade da monarquia portuguesa não estava assegurada aos olhos do movimento pela independência da Venezuela. Fatores para insegurança não faltavam. A fuga de espanhóis realistas pela fronteira com o Brasil, e o refúgio de alguns deles na América portuguesa foi fato conhecido pelas autoridades dos dois lados da fronteira. Dom Christovam Garcia, Domingos José Soares, João de Santiago Marques e José Maria Soares que entraram no Brasil por Marabitanas e lá ficaram refugiados, são casos citados em documentação oficial da administração portuguesa na América. ${ }^{204}$

O caso de Francisco Orosco, republicano capturado pelas forças realistas, que foi entregue aos cuidados de Pedro Miguel Ferreira Barreto, em Marabitanas, pelo general José Benito Lopez, tenente do real exército espanhol estabelecido em São

\footnotetext{
${ }^{204}$ São relacionadas como testemunhas no processo instaurado para apuração da conduta de Ferreira Barreto, comandante de fronteira no forte de São José de Marabitanas. FERREIRA REIS, Arthur Cezar, Neutralidade e boa vizinhança no início das relações entre brasileiros e venezuelanos documentário, op. cit., p. 70-74.
} 
Carlos, ${ }^{205}$ seria motivo de incertezas muito maiores quanto à posição portuguesa na América. Depois de semanas de correspondências, entre o tenente realista e o oficial português, este último, prudentemente, negou os pedidos de munição, homens e suprimentos do primeiro, mas acolheu sua solicitação quanto à custódia do prisioneiro Orosco em ofício de 3 de dezembro de $1817 .^{206}$

Pouco tempo depois, a situação política da fronteira foi alterada pela tomada de São Carlos pelo movimento republicano. Quase um mês após o primeiro contato estabelecido por Hipólito Cuevas, o próprio general Páez teria encaminhado uma carta a Ferreira Barreto exigindo a liberdade de Orosco - segundo transcrição do próprio Barreto -, nos seguintes termos:

“(...) que V.S. se digne poner a la persona del ciudadano Orosco en libertad en la inteligencia que en la actualidad no espero más que su favorable respuesta, y de lo contrario no solamente pereseran todos los prisioneros si no yo mismo en jefe con cuatro mil y quinientos hombres que tengo; con la artillería suficiente, a fin de solicitar su persona (...)". ${ }^{207}$

Improvável que para libertar um companheiro de armas, Páez tomasse uma atitude que pudesse conduzir a república venezuelana à guerra com vizinhança monarquista - situação extremamente indesejável para ambos os lados. Contudo, a provisoriedade das relações políticas no período e as inseguranças inerentes às

\footnotetext{
${ }^{205}$ Atual Estado do Amazonas, na Venezuela. Mapa: anexo 3.

${ }^{206} \mathrm{O}$ início de tal correspondência foi iniciativa do oficial espanhol no início do mês de novembro daquele ano. FERREIRA REIS, Arthur Cezar, Neutralidade e boa vizinhança no início das relações entre brasileiros e venezuelanos - documentário, op. cit., p. 15-22.

${ }^{207}$ Carta de José Antonio Páez a Pedro Miguel Ferreira Barreto, de18 de janeiro de 1818 . Documento anexo ao ofício de Ferreira Barreto ao Governador José Joaquim Vitorino da Costa, de 8 de fevereiro de 1818. Ibdem, p. 41-42.
} 
circunstâncias, tornaria compreensível uma ação semelhante, mesmo que equivocada. Aos olhos daqueles homens, a fronteira entre a América portuguesa e a incipiente República da Venezuela era um espaço político sem limites definidos ademais de, em certa medida, compartilhado. A instabilidade do presente e incerteza do futuro próximo impossibilitavam definições em relação à vizinhança, que em último caso, representava um opositor potencial.

Oficialmente, encontra-se apenas uma determinação de Simón Bolívar, "chefe supremo da República da Venezuela", em relação à fronteira com o Brasil:

"Suministren Vds. al señor coronel Juan Liendo la tela necesaria para un Pabellón Nacional para el castillo que divide el territorio de la República con el del gobierno de Brasil, e igualmente la necesaria para el Pabellón de la flechera que conduce a dicho señor coronel a Río Negro". ${ }^{208}$

Não há confirmação do cumprimento da ordem de Bolívar, mas a preocupação no estabelecimento de marcos visíveis da fronteira demonstram a necessidade em esclarecer os limites com o vizinho monarquista. Ou seja, precisava-se determinar marcos que pudessem atestar a neutralidade ou a hostilidade - no caso de ultrapassarem a fronteira estabelecida - em relação ao território do Brasil. Esta necessidade de definir uma postura segura era preocupação dos governos de ambos os lados da fronteira. Para a administração portuguesa na América a tarefa seria tão árdua e imprecisa quanto para república venezuelana. ${ }^{209}$

\footnotetext{
${ }^{208}$ Carta de Simón Bolívar aos "Señores ministros de estas Casas", Angostura, 22 de novembro de 1818. In.: Cartas del Libertador, op. cit., p. 146.

${ }^{209}$ PIMENTA, João Paulo Garrido. O Brasil e a América Espanhola (1808-1822), op. cit.
} 
3.2- A contestação da ordem metropolitana em Pernambuco, 1817: um ensaio republicano no Brasil.

Internamente, o Estado português sediado no Rio de Janeiro seguia com os esforços voltados à manutenção do sistema monarquista, ameaçado pelas convulsões no mundo ocidental daquelas últimas décadas. Para cobrir os gastos da Corte e financiar a guerra na região platina, promoveu-se o recrudescimento da cobrança de impostos, aumentando a oposição de interesses entre a aristocracia nativa e agentes do governo português, agora no Rio de Janeiro, principalmente no tocante às articulações comerciais.

Especialmente a Capitania de Pernambuco, uma das mais importantes da América portuguesa, ${ }^{210}$ atravessava um período de grave crise. Com a economia baseada na agricultura para exportação, o período era de sérias dificuldades causadas pela queda do preço do açúcar e algodão - dínamos econômicos da região - no mercado externo. Com a predominância da produção agrícola exportadora, a frequente escassez de gêneros de primeira necessidade havia aumentado devido às consequências da grande seca de 1816. Tal quadro era substancialmente agravado pela política praticada pela administração portuguesa em sua nova sede, que frequentemente recorria a empréstimos públicos ${ }^{211}$ e utilizava abusivamente dos mecanismos de tributação, sobrecarregando os grandes proprietários e encarecendo

\footnotetext{
${ }^{210} \mathrm{O}$ porto de Recife era um pólo dinamizador através do qual articulava-se toda economia regional: Ceará, Rio Grande do Norte, Paraíba, Alagoas e Sergipe. Vide: MOTA, Carlos Guilherme, op. cit.; BERNARDES. Denis Antônio de Mendonça. O Patriotismo Constitucional: Pernambuco, 1820-1822. São Paulo - Recife: Editora Universitária UFPE, Hucitec, FAPESP, 2006, p. 59-100.

211 "De todos os erários, era o de Pernambuco que menos tinha para descansar; os saques e re-saques da Corte e de outros erários [provinciais] eram quase cotidianos." Texto de autor não identificado. In.: COSTA, F. A. Pereira da. Anais Pernambucanos, 2a edição, 10 vols., Recife, 1983-1987, VIII, p. 17. Citado por MELLO, Evaldo Cabral de. A outra independência. O federalismo pernambucano de 1817 a 1824. São Paulo: Editora 34, 2004, p. 30.
} 
ainda mais os gêneros de primeira necessidade, atingindo a população livre e não proprietária.

Assim, a crise que persistia no Império português revelava-se nos conflitos que emergiam em todas as áreas da sociedade pernambucana. Os antagonismos eram agravados pela concentração do poder econômico, consequência da apropriação dos meios de produção e do poder político e pelas práticas das autoridades locais. ${ }^{212}$

Em 6 de março de 1817, com a participação de diversos setores da sociedade comerciantes, proprietários, membros do clero, militares, artesãos e uma camada de homens livres - iniciou-se, em Pernambuco, um movimento que propôs e executou, durante 74 dias, o rompimento com o domínio português na região, e a adoção de um sistema republicano de governo. ${ }^{213}$

Foi estabelecida uma junta de governo como forma mais adequada para compor o Governo Provisório da República de Pernambuco, ambos formados por elementos dos setores dominantes daquela sociedade, que assumiram a liderança do movimento. ${ }^{214}$ Segundo uma publicação da Bahia, este novo governo "mostrou uma atividade pouco conhecida no Brasil. Expediram-se proclamações garantindo a propriedade dos indivíduos, animando a independência, e a diminuição dos impostos, aumento do soldo da tropa e pagamento de seis meses adiantados aos administradores

212 LEITE, Glacyra Lazzari. Pernambuco 1817. Recife: Fundação Joaquim Nabuco, Editora Massangana, 1988, p. 88.

${ }^{213}$ Sobre a Revolução de Pernambuco: BERBEL, Márcia Regina. Pátria e patriotas em Pernambuco (1817-1822) nação, identidade e vocabulário político. In.: István JANCSÓ (org.). Brasil: Formação do Estado e da nação, op. cit., p. 345-364; BERNARDES, Denis Antônio de Mendonça. O Patriotismo Constitucional: Pernambuco, 1820-1822, op. cit.; LEITE, Glacyra Lazzari. Pernambuco 1817, op. cit.; MOTA, Carlos Guilherme. Nordeste 1817: estruturas e argumentos. São Paulo: Perspectiva, 1982; SILVA, Luiz Geraldo. "Pernambucanos, sois portugueses!" In.: Almanack Braziliense n' 1, maio de 2005. In.: Revista eletrônica: http://www.almanack.usp.br

${ }^{214}$ O Governo provisório era formado por: Manuel Correia de Araújo, expoente da elite agrária; Domingos José Martins, dos comerciantes; José Luís de Mendonça, dos magistrados; Domingos Teotônio Jorge Martins Pessoa, dos militares; e o padre João Ribeiro Pessoa de Melo Montenegro, presidente do governo e líder do clero. Outros nomes de grande representatividade na capitania integraram um conselho para assessoria do governo, entre eles Antônio Carlos Ribeiro de Andrada, irmão de José Bonifácio de Andrada e Silva. 
civis e militares". ${ }^{215}$ Os poderes deste governo foram regulamentados por uma lei orgânica de 28 artigos, encaminhada a todas as Câmaras da comarca constitutivas da antiga Capitania. ${ }^{216}$ Com fórmulas avançadas de organização do poder, era baseada na doutrina do povo soberano, na convocação de uma constituinte, na tolerância religiosa, proibição de atos de perseguição por motivos de consciência e proclamação da liberdade de imprensa. ${ }^{217}$

Além dos fundamentos legais, o movimento republicano em Pernambuco apresentava outras feições políticas que poderíamos considerar modernas. Alterações nas formas de sociabilidade, com o uso de "vós" nos tratamentos pessoais, ${ }^{218}$ estabelecendo a ideia de igualdade entre todos; no vocabulário político, por exemplo, o uso do termo "patriota"; a criação de uma bandeira para República; e a impressão da "Declaração dos Direitos Naturais, Civis e Políticos do Homem" na Oficina Tipográfica da República de Pernambuco. Enfim, esforços claramente inspirados nas referências de valores modernos, que pretendiam apagar as lembranças coloniais e as insígnias da realeza portuguesa.

Neste sentido, Carlos Guilherme Mota assinala a influência de leituras francesas no Brasil desde o final do século XVIII: escritores como Raynal, Mably, Rousseau, Morelly, Volney, Voltaire, Montesquieu, Tugot e Brissot entre outros eram lidos em Minas Gerais, no período da Inconfidência de 1789, e também na região portuária do Rio de Janeiro. Em Salvador, Rousseau e Volney eram parcialmente

\footnotetext{
${ }^{215}$ Jornal de acontecimentos na Bahia, extraído das gazetas francesas - Nantes 5 de junho [1817]. In.: Correio Braziliense n. ${ }^{\circ} 109$, junho de 1817, vol. 18, op. cit., p. 666.

${ }^{216}$ MELLO, Evaldo Cabral de, op. cit., p. 49-51.

${ }^{217}$ MOTA, Carlos Guilherme. Nordeste 1817, op. cit., p. 54-55; CABRAL, Flavio José Gomes. A República de Pernambuco. In.: Revista de História da Biblioteca Nacional, n. ${ }^{\circ} 30$, março de 2008.

${ }^{218}$ Um contemporâneo que testemunhou o ocorrido em Pernambuco registrou o seguinte comentário junto à narrativa dos fatos: "Prescrevem imediatamente os tratamentos, dando somente o de vós; o que prova bem a falta de senso; pois é natural que um escravo trate a seu senhor, da mesma maneira que este ao escravo!". "Narrativa da Revolução em Pernambuco por uma testemunha ocular." In.: Correio Braziliense n. ${ }^{\circ}$ 109, junho de 1817, op. cit., vol. 18, p. 663.
} 
transcritos nos cadernos de preces dos sediciosos de $1798 .{ }^{219}$ Evidente que Recife não era exceção quanto a circulação destes e outros impressos que alimentavam uma esfera mental impregnada de novos referenciais políticos e sociais. ${ }^{220} \mathrm{O}$ contexto inaugurado a partir da instituição da imprensa no Brasil, em 1808, era, como vimos, ainda mais favorável à circulação destas ideias. O fluxo de informações tornou-se mais dinâmico promovendo conexões maiores com os acontecimentos e suas representações, num espaço que tendia a abranger todo o mundo ocidental.

Antes da eclosão do movimento de 1817, o vocábulo revolução já fazia parte do universo linguístico português, e das preocupações da polícia da província de Pernambuco. Os inquéritos revelam, por exemplo, que em 1815, João Nepomuceno Carneiro da Cunha era acusado de haver pregado a "revolução"; o vigário de Recife, padre Antônio Jácome Bezerra - detido em 22 de maio de 1817 - fora acusado de tratar da "revolução" sete anos antes; os padres Francisco Muniz Tavares, Francisco de Sales, João Gomes de Lima, João Cavalcanti de Albuquerque eram clérigos acusados de há tempos na sombra da maçonaria tratarem de "revolução". ${ }^{221}$ Utilizado para acusações, o termo servia para designar ações ofensivas à ordem estabelecida. Desde 1813 a Língua portuguesa já havia registrado o uso termo nesta direção, ou seja, com sentido político para designar alteração da ordem. ${ }^{222}$ Ideia diretamente

\footnotetext{
${ }^{219}$ MOTA, Carlos Guilherme. Nordeste 1817, op. cit., p. 31.

${ }^{220}$ Segundo HABERMAS - Historia y critica de la opinión pública, op. cit. -, a circulação de impressos e o desenvolvimento de novas formas de sociabilidade compõem um conjunto de práticas viabilizadas pelo meio urbano. Esta hipótese é de certa forma confirmada pelos exemplos citados por Carlos Guilherme MOTA.

${ }^{221}$ Documentos Históricos da Biblioteca Nacional. Divisão de obras raras e publicações. Rio de Janeiro, 1954, vol. 104, p. 49-51.

${ }^{222} \mathrm{O}$ "Diccionario da lingua portugueza" de 1813, já atribuía ao verbete revolução um sentido político, mesmo que não prioritariamente: "s. f. Movimento pela órbita, giro; v.g. revolução dos astros, planetas. Vieira, essa revolução dos Ceos. § Hum giro inteiro do planeta na sua órbita. Revolução fizica do mundo, alterações como terremotos, submersões de terra, \& c. § Revolução de humores no corpo. $\S$ fig. Revoluções nos estados, mudanças na fórma, e política". SILVA, Antonio Moraes. Diccionario da lingua portugueza recopilado dos vocabularios impressos até agora, e nesta segunda edição novamente emendado, e muito accrescentado, por Antonio de Moraes Silva natural do Rio de Janeiro. Offerecido ao muito alto, e muito poderoso Principe Regente N. Senhor. Lisboa: Typographia Lacerdina, 1813, p. 629.
} 
relacionada à subversão promovida pela experiência francesa de 1789, como veremos mais adiante. $^{223}$

Contudo, não podemos analisar um movimento de tão larga amplitude, como este de Pernambuco em 1817, resumindo suas motivações ao descontentamento geral em relação ao governo português, e à sua negação, associada a uma mudança gradativa de mentalidade. Devemos considerá-lo também como processo coordenado por membros das camadas dirigentes da sociedade pernambucana, que articularam seus interesses à insatisfação de grande parte da população. A grande maioria dos homens, livres e pobres, não possuía consciência exata da situação política a qual estavam submetidos. Para eles, embora sofressem diretamente as consequências da política econômica aplicada, a motivação imediata era de ordem social, de subsistência, e não do questionamento da lógica sob a qual a política portuguesa era exercida. A carestia empurrou esta camada da sociedade, ávida por qualquer alteração da ordem que esboçasse a possibilidade de melhora, para as linhas do movimento de 1817.

A vinculação deste anseio de mudança com uma proposta de alteração da ordem foi consequência do alargamento dos espaços públicos de discussão e a difusão de um ideário repleto de conteúdos inovadores, ambos potencializados pela ampliação da circulação de periódicos impressos, que conforme já assinalado, não se restringia aos círculos letrados.

Retornando a esfera dos eventos, a rapidez na formação do Governo Provisório, nas publicações de proclamações bem elaboradas e a extensão do movimento à Paraíba, Rio Grande do Norte e Ceará, evidenciam a articulação prévia do movimento. E, mesmo sendo posteriormente debelado pelas autoridades reais,

\footnotetext{
${ }^{223}$ Uma análise sobre as concepções do termo revolução é realizada no capítulo seguinte.
} 
denunciava a gravidade da crise geral do Antigo Regime no universo luso-americano, já não apenas como motivo de apreensão, mas, sobretudo, de comprovação da proximidade do Brasil com o convulsionado mundo hispano-americano. ${ }^{224}$

As atenções eram recíprocas. A América espanhola não ignorou os acontecimentos de Pernambuco. Importantes periódicos em circulação na época, como os portenhos a Gazeta de Buenos Aires, a Crónica Argentina e Censor, ${ }^{225}$ e, na Venezuela, a Gaceta de Caracas, mostraram-se atentos ao movimento que deu eco à revolução na América portuguesa. Este último, em sua edição de 10 de dezembro de 1817, reproduziu trechos do periódico publicado na Bahia, Idade d'Ouro no Brasil, de 30 de maio daquele ano, noticiando a derrota do movimento revolucionário:

"Hiciéronse muchos prisioneros, y hubo gran número de muertos y heridos de parte delos insurgentes, siendo la mayor parte oficiales, y tambien algunos cabezas de la rebelión.

'Después de esta acción se supo que el insurgente Martins marchaba sobre Serinhaem mandando una columna, y se destacó un cuerpo de 300 hombres al mando del capitán de milicias de la villa de Penedo, Antonio Josef de los Santos, quien la desbarató completamente, cogiendo entre otros muchos al célebre caudillo de la Revolución.'

Divulgada en esta capital tan grata noticia se juntó un inmenso concurso enfrente de palacio, y habiendo tenido la satisfacción de ver S.M. que salía en su coche, gritó repetidas veces el Rey, manifestando su lealtad y regocijo con las más expresivas demostraciones, las que recibió S. M. con su bondad característica;

\footnotetext{
${ }^{224}$ PIMENTA, João Paulo Garrido. O Brasil e a América Espanhola (1808-1822), op. cit., p. 220-221.

${ }^{225}$ PIMENTA, João Paulo Garrido. Estado e nação no fim dos Impérios ibéricos no prata (1808-1828), op. cit., p. 153-160.
} 
con tan plausible motivo hubo repique general de campanas, salvas de artillería e iluminación general", 226

Assim, a Gaceta de Caracas usa o termo revolução como sinônimo de rebelião, insurreição, ou seja, contestação à boa ordem estabelecida. A descrição de uma grande vitória monarquista e a consequente felicidade do povo que exaltou feliz o seu "bondoso" rei, era, sem dúvida, elemento de grande valia na argumentação realista da Gaceta de Caracas. A vizinhança monarquista oferecia um exemplo a ser seguido para restauração da paz e tranquilidade na América espanhola. Em maio de 1819, ano da instauração do Congresso republicano em Angostura, esta relação foi explicitada. A "insurreccion de Pernambuco" constou na reunião dos argumentos do periódico realista da Venezuela:

“¿Por qué no indicó los recientes esfuerzos de algunas colonias holandesas para romper el yugo de fierro; la insurrección de Pernambuco, à pesar de las franquías y nuevo orden Braziliense, y otras rebeliones apoyadas en manifestos contra a la tiranía europea? Conveníale sin duda callar, y no exacerbar mas a los jueces ante quienes aboga su causa. Pero nosotros (puedo yo decir haciendo mías las palabras del manifiesto) 'hablamos a las naciones del mundo, y no podemos ser tan impudentes', que nos propongamos engañarlas en lo mismo que ellas han visto y palpado; y concentrándome a las de Europa, que tienen en sus manos la balanza de los destinos de América, bien puedo apostrofar segunda vez: oid ¡Õ Reys! Y escarmentad naciones: Erudimini". ${ }^{227}$

\footnotetext{
${ }^{226}$ Gaceta de Caracas, n. ${ }^{\circ} 163,10$ de dezembro de 1817, op. cit., vol. 6, p. 1265 (grifos meus).

${ }^{227}$ Gaceta de Caracas, n. $^{\circ}$ 249, de 26 de maio de 1819, op. cit., vol. 7, p. 1922 (grifo meu).
} 
O fim do movimento de Pernambuco, portanto, foi apresentado como vantajoso. Esta era uma lição que deveria ser aprendida - Erudimini. O editor da Gaceta de Caracas ainda nos permite identificar, mais uma vez, a necessidade da publicidade das causas que conduzem a América no continente europeu - que na sua visão poderia decidir os destinos americanos. Resumindo, são eventos da América portuguesa utilizados em argumentos hispano-americanos realistas que se voltam para o território europeu, local a partir de onde as informações irradiavam para o restante do mundo ocidental. Ou seja, a trama de mesmo contexto multifacetado, um único espaço de experiência, onde o mundo ibero-americano estava inserido como emissor e receptor de ideias que impulsionavam as respectivas ações políticas.

Também interessado nos desdobramentos do movimento de contestação da ordem monárquica na vizinhança portuguesa, o Correo del Orinoco, provocou um caloroso debate com o Correio Braziliense, motivado pelos acontecimentos de 1817 em Pernambuco. Esta contenda impressa, objeto do nosso trabalho, estudada no capítulo seguinte, nos oferece elementos significativos para compreender a heterogeneidade americana, nesta conjuntura, no mundo ocidental, estabelecida pela emergência de novas referências para práticas sociais e políticas que, progressivamente, sobrepujaram as bases estruturais do Antigo Regime e, como seu desdobramento, do sistema colonial.

Retomando a situação portuguesa no plano externo, o governo lusitano na América necessitava manter sua política de neutralidade quanto à guerra na vizinhança hispânica. Como citado, naquele mesmo ano de 1817, autoridades do governo português subordinadas ao Estado do Grão-Pará e Maranhão, fronteira com os territórios da América espanhola do Vice-Reino de Nova Granada e da Capitania 
Geral da Venezuela, tiveram contatos significativos tanto com oficiais realistas quanto com republicanos.

Em ofício de 18 de dezembro de 1817 o tenente Pedro Miguel Ferreira Barreto, oficial responsável pelo forte de São José de Marabitenas, ${ }^{228}$ comunicou a seu superior imediato, José Joaquim Vitório da Costa, 229 a situação "arriscada a algum conflito" que se encontrava aquela fronteira. ${ }^{230}$ A tomada de Angostura pelas forças independentistas, e seus avanços pelo rio Orinoco pressionavam os exércitos realistas posicionados na região, obrigando-os ao recuo em sentido contrário, ou seja, na direção dos limites com a América portuguesa.

Neste contexto, o tenente realista espanhol, José Benito Lopez, estabelecido na fortificação de San Carlos del Río Negro, encaminhou ao tenente Ferreira Barreto, quatro ofícios pedindo reforços de homens, munições e uma embarcação. ${ }^{231}$ Argumentando sobre um "histórico" de amizade, aliança e cooperação entre as coroas portuguesa e espanhola, solicitou também a transferência de Francisco Orosco, prisioneiro acusado de adesão ao movimento revolucionário e conspiração contra a monarquia espanhola, para o forte de Marabitenas - no lado português da fronteira. Prudente, Barreto nega o fornecimento dos reforços solicitados alegando o dever de “olhar o futuro e as atuais circunstâncias" em que se achavam. Contudo, aceita a custódia de Orosco, “com todas as cautelas e seguranças necessárias" à sua fronteira. ${ }^{232}$ Ao informar o governador Vitório da Costa, Barreto justificou a aceitação da transferência do prisioneiro "não só pelos seus atrozes crimes", mas também,

\footnotetext{
${ }^{228}$ Mapa: anexo 3

${ }^{229}$ Responsável pela administração da Capitania de São José do Rio Negro - submetida ao Estado do Grão-Pará -, substituído em princípios do ano de 1819 pelo Cel. Manoel Joaquim do Paço.

${ }^{230}$ REIS, Arthur Cezar Ferreira, Neutralidade e boa vizinhança no início das relações entre brasileiros e venezuelanos - documentário. In.: Revista do Instituto Histórico e Geográfico Brasileiro, vol. 235, abril-junho de 1957, p. 14.

${ }^{231}$ Ofícios datados de 13, 26 e 30 de novembro de 1817, e o último, de 06 de dezembro do mesmo ano. José Benito Lopez a Miguel Ferreira Barreto. In.: REIS, Arthur Cezar Ferreira, op. cit., p. 14-18.

${ }^{232}$ Ferreira Barreto a José Benito Lopes, 16 de novembro de 1817 e 3 de dezembro de 1817, respectivamente. Ibdem, p. 18.
} 
“porque não me fio em tê-lo aqui solto, por ser assaz astuto, e poder com suas maldades, e más conversações, as quais lhe tenho privado seduzir a Tropa, ou Índios ao seu partido. $" 233$

A atitude de Barreto provocou grande inquietação das autoridades portuguesas não só da Capitania do Rio Negro, como do Estado do Grão-Pará, pois a proximidade do movimento republicano - cujas vitórias eram publicamente sabidas pela governança lusitana, que havia experimentado seu "gosto amargo" em Pernambuco no início daquele ano - exigia esforços redobrados na tentativa de sustentação da política de neutralidade em relação à América espanhola. A aceitação da custódia de Orosco pelo comando de Marabitanas poderia "provocar contra si o ódio dos rebeldes de Goiana”. Ciente da instabilidade do universo político hispano-americano, Vitório da Costa, ao repreender o tenente Ferreira Barreto, ordenou a liberação de Orosco e salientou o risco de "amanhã os rebeldes, que aí agora são inculpados, poderão ser dispersos, que no dia seguinte, os negócios da nossa Corte com a de Madri poderão mudar de face, que em sequência disto poderá ter pela proa os Espanhóis de S. Carlos, a quem indiscretamente franqueou Meios para o ataque.” Outra preocupação neste sentido era que "os rebeldes da Goiana chegando a assenhorearem-se de São Carlos nessa fronteira espanhola não achariam ali munições para nos atacar”. ${ }^{234}$

O contato com os realistas espanhóis era prova de que as guerras do território hispânico havia chegado à fronteira da América portuguesa, motivo de grande inquietação para os homens responsáveis pelo governo lusitano daquela localidade. O receio de uma possível guerra contra a turbulenta vizinhança transformou-se em motivo para providências concretas de prevenção em relação a um "iminente" ataque dos republicanos. O temor gerado pela proximidade dos agentes do convulsionado

\footnotetext{
${ }^{233}$ Solicitou ainda, lampiões e manteiga necessários aos trabalhos de segurança da fronteira. Ofício de Ferreira Barreto a Vitório da Costa, Marabitanas, 18 de dezembro de 1817. Ibdem, p. 14-15.

${ }^{234}$ Vitório da Costa a Ferreira Barreto. Barra de Rio Negro, 28 de janeiro de 1818. Ibdem, p. 28.
} 
processo venezuelano norteou, em boa parte, as ações do governo lusitano naquela fronteira.

Em março do ano seguinte, quando Vitório da Costa levou a situação ao conhecimento do governador geral do Grão-Pará, conde de Vila Flor, solicitando aumento de contingente, novas guarnições e pólvora, descreveu o seguinte quadro:

"No presente estado de Coisas, em que os rebeldes da Goiana são nossos confinantes, e portanto a audácia se acha às portas de nossa Fronteira de Marabitenas, é necessário dar agora a esta fronteira uma certa força capaz de enfrear pela sua presença a audácia de tais vizinhos, e capaz de resistir por algum tempo pelo seu efeito a hum imprevisto ataque precipitado por eles sobre nós, esperando que outras forças a ela se reúnam. Para formar a força mencionada que a de fazer respeitar a nossa Fronteira de Marabitenas pelos nossos vizinhos de hoje, inquietos e audaciosos, sem contudo deixar desguarnecidos, e indefesos outros Postos principais desta Capitania (...)".235

As preocupações não se restringiam ao forte de Marabitanas. Em ofício de julho de 1818, José Joaquim Vitório da Costa trata de outros pontos da fronteira com a "Guayana espanhola":

“(...) entendo, que V. Exa. Se persuadirá, que é necessário aplicar agora à nossa Fronteira da banda de Rio Branco uma força capaz de fazer respeitada dos nossos vizinhos por aquela banda: o que assim

\footnotetext{
${ }^{235}$ José Joaquim Vitório da Costa ao Conde de Vila Flor. Barra do Rio Negro, 17 de março de 1818. REIS, Arthur Cezar Ferreira, op. cit., p. 37.
} 
sendo, se é necessário acrescentar agora a força desta Capitania, como eu já instruí a V. Exa. Por meu Officio - nº 177 -, para por em respeito a nossa Fronteira da banda do Rio Negro, também é necessário para por em respeito a nossa Fronteira da banda do Rio Branco". 236

Em resposta aos ofícios da Capitania de São José do Rio Negro, o Conde de Vila Flor determinou o plano de ações que deveria ser adotado para preservação dos domínios portugueses na América:

"Por nenhum modo Vm. consinta as menores relações dos Povos daquela Capitania com os das Províncias insurgidas espanholas, empregando todos os meios que lhe forem possíveis para cortar toda a comunicação que possa haver entre eles.

Para isto, deverá Vm. ter sempre as fortalezas das Fronteiras em estado de poderem obstar a quaisquer tentativas, que possam fazer águas partidas dos Insurgentes, reforçando com maior número de tropa tanto de Linha como de Milícias aqueles pontos que o precisam mais procurando fazer respeitar a integridade do nosso território, e sustentar os direitos d'El Rey Nosso Senhor. É essencialmente necessário que $\mathrm{Vm}$. tenha as mais exatas notícias e informações do progresso do espírito revolucionário nos paises limítrofes da Capitania, da força armada, que tem naquelas fronteiras, movimentos e direção dos Corpos, e das disposições hostis, ou

\footnotetext{
${ }^{236}$ José Joaquim Vitório da Costa ao Conde de Vila Flor. Barra do Rio Negro, 30 de julho de 1818. In.: REIS, Arthur Cezar Ferreira, op. cit., p. 46.
} 
pacificas a nosso respeito (...)". ${ }^{237}$

Assim, o comando da capitania do Rio Negro seguia as orientações do governo do estado do Pará empreendendo todos os esforços possíveis para manutenção da política de neutralidade do governo português, tendo como principal medida impedir o contato de seus agentes na fronteira com o movimento republicano da Venezuela, pois, como salientado por Vila Flor, não se tinha clareza do "estado das relações políticas com os americanos espanhóis", assim sendo, deveriam manter-se em "estado de defesa". 238

Antes que as orientações sobre como proceder pudessem chegar até ele, Ferreira Barreto, sem descuidar da fortificação da fronteira, empreendeu ativa comunicação com os comandantes republicanos estabelecidos na região tentando, à sua maneira, preservar as fronteiras da coroa lusitana na América. Chegou a encaminhar resposta à suposta carta do general Páez, e na busca de esclarecimentos sobre as intenções políticas do movimento independentista venezuelano em relação à América portuguesa, escreveu a Hipólito Cuevas:

“(...) se me faz necessário que Vm. quando pretendam congratular-se com esta Fronteira e Nação me remetam um Tratado de neutralidade em todas as suas dependências e que declarem que nada exigem e nem pretendem de Portugal; porque dessa forma ficarei bem persuadido que a mencionada carta escrita em nome do cidadão Páez é traição de quem a escreveu (...) e a Vm. não me certificar com o

\footnotetext{
${ }^{237}$ Conde de Vila Flor a Manoel Joaquim do Paço. Pará, 27 de junho de 1818. In.: REIS, Arthur Cezar Ferreira, op. cit., p. 50-51. Possivelmente algum erro de identificação do destinatário, pois como citado pelo próprio Reis, Joaquim do Paço só substituiu Vitório da Costa, no comando da capitania do Rio Negro, em princípios de 1819.

${ }^{238}$ Conde de Vila Flor a Manoel Joaquim do Paço. Pará, 28 de março de 1819. In.: REIS, Arthur Cezar Ferreira, op. cit., p. 55.
} 
Tratado que lhe rogo então viverei na inteligência que é verdadeira e que o governo Republicano se tem desorganizado, porque $\mathrm{Vm}$. assegurando-me uma amizade sólida por outra parte me atacam com uma insultante carta; farei então meu juízo particular, e aplicativo sobre o que devo obrar. Espero pois, e confio da grande honra de Vm. que com eficácia me fale sobre o exposto."239

Inicialmente tensa, a correspondência evoluiu para uma troca de demonstrações recíprocas de boas intenções. Por fim, Ferreira Barreto consegue um "tratado de amizade" negociado com o coronel republicano Juan José Leandro, em Atabapo a 24 de fevereiro de $1819 .^{240} \mathrm{O}$ tenente de Marabitanas se compromete em encaminhar o tão festejado documento ao governador do estado, e adiantando-se, garantiu que o retorno ao movimento republicano seria de "iguais demonstrações de amizade, cuja resposta" teria "a honra de fazer enviar a esta República". ${ }^{241}$

A conduta de Barreto fora julgada no dia 23 de junho de 1819, por um conselho presidido por Manoel Joaquim do Paço, então comandante da Capitania de São José do Rio Negro. Segundo registros, tal julgamento tinha o objetivo de avaliar:

"Se os procedimentos do comandante da fronteira de Marabitanas, tem ou não o caráter de insubordinação e desobediência, vistas as ordens que tem recebido para se obter de toda a comunicação, trato e contrato com os insurgentes espanhóis daquela fronteira. Se há ou não motivos bastantes para supor e recear que no mesmo haja pouca

\footnotetext{
${ }^{239}$ Pedro Miguel Ferreira Barreto a Hipólito Cuevas. Marabitanas Fronteira de Portugal, 4 de março de 1818. In.: REIS, Arthur Cezar Ferreira, op. cit., p. 47-49.

${ }^{240}$ REIS, Arthur Cezar Ferreira, op. cit., p. 58-59. Atabapo é um município da Venezuela localizado no atual estado do Amazonas.

${ }^{241}$ Pedro Miguel Ferreira Barreto a Juan José Leandro, sem data registrada. In.: REIS, Arthur Cezar Ferreira, op. cit., p. 59-60.
} 
firmeza e falta de fidelidade ao Soberano e a Pátria no exercício do seu comando". 242

Os testemunhos tomados e os pareces sobre o caso foram encaminhados para sentença do governador, Conde de Vil Flor. Todos os pareceres concordaram sobre a desobediência de Ferreira Barreto - alguns assinalando a falta de intenção em seu erro -, mas também estavam de acordo sobre não haver nenhuma dúvida em relação ao patriotismo e lealdade do oficial. Contudo, Barreto foi destituído do cargo pelo Conde de Vila Flor, que ordenou a Joaquim do Paço sua prisão e envio a Belém. ${ }^{243}$

O julgamento de Ferreira Barreto nos dá a dimensão dos temores e cautelas dos oficiais portugueses responsáveis pela fronteira norte do Brasil em relação à convulsionada vizinhança. Os processos políticos na América espanhola durante a crise e dissolução do Antigo Regime compunham num espaço de experiência para o universo político luso-americano, que em medida considerável delimitou suas expectativas e, por conseguinte, suas condutas político-administrativas. Também nos permite perceber a falta de definições quanto aos procedimentos na execução da política de neutralidade pretendida pelo Estado português.

Por fim, os registros de envios e recebimentos de periódicos hispânicos, junto aos ofícios, evidenciam a avidez destes homens de governo por notícias de além da fronteira. Manter-se informado sobre o "progresso do espírito revolucionário nos países limítrofes da Capitania, da força armada, que tem naquelas fronteiras, movimentos e direção dos corpos, e das disposições hostis, ou pacificas"244 a respeito da América portuguesa, era essencial para a tomada de decisões na administração da

\footnotetext{
${ }^{242}$ REIS, Arthur Cezar Ferreira, op. cit., p. 63-64.

${ }^{243}$ Ibdem, p. 79.

${ }^{244}$ Conde de Vila Flor ao Governador da Capitania do Rio Negro. Pará, 27 de junho de 1818. In.: REIS, Arthur Cezar Ferreira, op. cit., p. 50-51.
} 
fronteira. A instabilidade política na América hispânica era vivenciada e apreendida pela América portuguesa através de documentos e negociações diplomáticas com a metrópole espanhola e com os agentes de movimentos hispano-americanos independentistas, mas, sobretudo, pela circulação das informações sobre a dinâmica dos processos revolucionários possibilitada principalmente pela imprensa periódica. Estas experiências influenciariam de maneira decisiva as políticas do Estado português na América e, posteriormente, o movimento de independência do Brasil e sua constituição em um Estado nacional. 


\section{CAPÍTULO 4: REVOLUÇÃO EM PAUTA:}

O debate entre o Correio Braziliense e o Correo del Orinoco

\section{1- Significados de revolução}

Nas primeiras décadas do século XIX, o universo linguístico do mundo ocidental passava por transformações significativas. A necessidade de apreensão e comunicação das novas circunstâncias estabelecidas pelas experiências profundas de mudança de formas tradicionais de existência - principalmente a francesa iniciada em 1789 - geraram tensões de muitos tipos implicando transformações do vocabulário em uso. ${ }^{245}$ Veremos como no mundo ibérico - o que inclui as respectivas possessões americanas - o uso do termo revolução foi fundamental para inteligibilidade dos processos iniciados a partir das investidas napoleônicas na península ibérica.

O termo originado do latin revolutio - volta, giro, rotação -, originalmente não tinha conotação política. Zermeño Padilla cita o uso do termo latino por Santo Agostinho no ano 400 d.C. para tratar das transformações que se operariam na alma após a morte do corpo: “a que corpo regressa a alma depois de tantas revoluções?”, questionava Santo Agostinho na $A$ cidade de Deus. ${ }^{246}$ Posteriormente, em outros escritos medievais, o termo revolução foi empregado pelas ciências naturais para designar o movimento dos corpos celestes em suas órbitas, indicando um movimento cíclico natural. O termo ganha importância no campo das ciências a partir da

\footnotetext{
${ }^{245}$ POCOCK, J. G. A.. Linguagens do ideário político. São Paulo: Edusp, 2003, p. 63-82.

${ }^{246}$ De civitate Dei, escrito entre os anos 413 - 426. Citado por ZERMEÑO PADILLA, Guillermo. $L a$ cultura moderna de la historia: una aproximación teórica e historiográfica. México: El Colegio de México, Centro de Estudios Históricos, 2002, p. 57.
} 
publicação da obra de Copérnico, Das Revoluções do Mundo Celeste, ${ }^{247}$ mantendo assim o sentido preciso do termo latino.

Segundo Padilla, a utilização do vocábulo revolução com sentido político feita pela primeira vez em Florença, no século XIV, pelos irmãos Giovanni e Matteo Villani, que usaram o termo comum às ciências da natureza para explicar os desequilíbrios manifestos nas revoltas populares, como os ocorridos na cidade de Siena em 1355. Em 1530, Francesco Guicciardini repete o uso do termo com o mesmo sentido e estabelece uma série de equivalências - rivoluzione, rebellione, rivolta - para descrever alterações nas formas de domínio resultantes de discordâncias internas. ${ }^{248}$ Apesar desta disponibilidade de uma conotação política, o uso do termo revolução, até meados do século XVII, estava predominantemente relacionado aos ciclos naturais. $^{249}$

A partir do século XVII verifica-se a tendência do uso do vocábulo revolução com um sentido político retrospectivo, aplicado para indicar uma rotação para um ponto preestabelecido e, implicitamente, de retorno a uma ordem anterior. Nas palavras de Arendt, o termo "começou por ser empregado, não quando aquilo a que chamamos uma revolução rebentou na Inglaterra e Cromwell fez surgir a primeira ditadura revolucionária, mas pelo contrário, em 1660, após a destituição dos restos do Longo Parlamento e por ocasião da restauração da monarquia". ${ }^{250}$ Com esse mesmo

\footnotetext{
${ }^{247}$ De revolutionibus orbium coelestium, 1543 , obra na qual Nicolau Copérnico defendeu a tese de que todos os planetas, inclusive a Terra, giravam em torno do Sol - heliocentrismo -, contrariando o modelo então vigente, proposto pelo matemático e astrônomo grego Claudius Ptolomeu (78-161 d.C.), segundo o qual o Sol e todos os demais planetas giravam em torno da Terra - geocentrismo.

${ }^{248}$ Fiorentine Historie ou Crônica Universale, obra iniciada Giovanni Villani no ano de 1300. Após sua morte, em 1348, o trabalho foi continuado por seu irmão, Matteo Villani e concluído por seu sobrinho, Filippo Villani, seguindo até o ano de 1364; Ricordi civili e politici (1512-1530) obra do escritor renascentista Francesco Guicciardini. Citados por ZERMEÑO PADILLA, Guilhermo. La cultura moderna de la historia, op. cit., p. 57-58.

${ }^{249}$ ARENDT, Hannah. Sobre Revolução, Lisboa: Relógio D’Água Editores, 2001; ZERMEÑO PADILLA, Guilhermo. La cultura moderna de la historia, op. cit.; KOSELLECK, Reinhart. Critérios históricos do conceito de revolução. In.: Futuro Passado, op. cit., p. 61-78.

${ }^{250}$ ARENDT, Hannah. Sobre Revolução, op. cit., p. 49-50.
} 
sentido, ao fim do processo inglês iniciado em 1639-1640, "Hobbes descreveu os vinte anos passados num movimento circular que havia conduzido desde ao monarca absoluto, passando pelo parlamento, e deste, à ditadura de Cromwell e, de volta, através de formas oligárquicas intermediárias, à monarquia, restaurada com Carlos II". ${ }^{251}$ Desta forma, a palavra revolução no aspecto político teria o significado de restauração, ou seja, de restabelecer algo nos parâmetros do passado. Segundo Arendt, devemos considerar os movimentos iniciais das revoluções do século XVIII a americana e a francesa - também neste sentido, pois seus agentes estariam firmemente convencidos de que agiam no sentido de restaurar uma antiga ordem de coisas, perturbada e violada pelo despotismo da monarquia absoluta ou pelos abusos do governo colonial. Somente no decorrer dos respectivos processos que se tomaria consciência da impossibilidade de qualquer restauração e da necessidade de empregar esforços num empreendimento totalmente inédito. Portanto, quando o próprio vocábulo revolução já havia adquirido um novo significado ${ }^{252}$ - que coexistia com outros estabelecidos anteriormente. Consolidava-se a concepção do termo vinculada à noção do novo, ou seja, caracterizada pela ruptura, diferente da ideia expressa no século XVII que relacionava revolução à ideia de um movimento de restauração de uma ordem anterior.

Assim, devemos considerar que o desejo de retorno a tal "ordem perturbada e violada", motivação para desencadeamento dos referidos movimentos que puderam ser tratados, em suas épocas e/ou por estudos posteriores, por revolução, era estabelecido por ideais subjetivos, relacionados a direitos e liberdades, definidos pela mutação de valores e referências de comportamentos desenvolvidos a partir do século XVIII - na qual as projeções para o porvir se desvinculavam cada vez mais das

\footnotetext{
${ }^{251}$ KOSELLECK, Reinhart. Critérios históricos do conceito de revolução. In.: Futuro Passado, op. cit., p. 64-65.

${ }^{252}$ ARENDT, Hannah, op. cit., p. 51.
} 
experiências até então conhecidas. Os acontecimentos do passado já não eram suficientes para fundamentar as expectativas geradas pelas novas referências. ${ }^{253}$

Dessa maneira, a partir da experiência francesa de 1789, o termo revolução passou a ser usado também para descrever um movimento até então inédito, de subversão da ordem política e social. A necessidade de expressão desta nova experiência promoveu uma re-significação do termo na esfera dos discursos, definindo um conceito de revolução intrinsecamente ligado à noção do novo, de transformação como resultado da ação consciente do homem, impulsionada pela ideia de justiça e liberdade.

O desenvolvimento do processo francês, com a ascensão dos jacobinos, a Proclamação da República em 1792 e a execução de Luis XVI, em janeiro de 1793, promoveu uma ideia negativa de revolução relacionada ao radicalismo e ao excesso. O temor a esta ideia deu início à construção de uma representação simbólica da Revolução Francesa que enfatizava aspectos supostamente negativos de seus desdobramentos, como a violência e o terror. Esta noção foi reforçada no final da era napoleônica, após o Congresso de Viena - entre os anos de 1814 e 1815. Os países ali reunidos tinham por objetivo redesenhar o mapa político do continente europeu, garantindo a paz necessária para a restauração dos princípios da legitimidade monárquica violados por Napoleão Bonaparte. A partir de então, para a política das monarquias restauradas - contexto coincidente com o período do debate estudado -, o exemplo radical da França revolucionária deveria ser condenado e evitado a todo custo.

A necessidade de reação diante dos acontecimentos na Europa força um reordenamento do mundo ibero-americano, desencadeando processos políticos cujas

\footnotetext{
${ }^{253}$ KOSELLECK, Reinhart. 'Espaço de experiência' e 'horizonte de expectativa': duas categorias históricas. In.: Futuro Passado, op. cit.; ZERMEÑO PADILLA, Guilhermo. La cultura moderna de la historia, op, cit.
} 
trajetórias podem ser caracterizadas, principalmente, pela instabilidade, provisoriedade e imprevisibilidade das formas políticas e, de certo modo, também de praticamente quase todos os níveis da realidade social. Neste contexto, ampliou-se a capacidade do termo revolução para designar estados presentes e anunciar outros inéditos. Convertido em conceito fundamental para apreensão dos processos por seus agentes, assim como sustentáculo dos discursos sócio-políticos, revolução é um dos termos chaves para a compreensão dos decursos que culminaram nas independências políticas na América ibérica.

Neste sentido, Fabio Wasserman fez um balanço das nuances e ambiguidades dos sentidos de revolução coexistentes no espectro dos discursos, na região do Rio da Prata, relacionadas ao estabelecimento de uma nova ordem, e que podem ser em alguma medida generalizadas, de modo a explicar o que ocorria com o conceito em outras partes da América. ${ }^{254}$

Como já apresentado, uma definição negativa do termo revolução relacionada a convulsões sociais, e frequentemente utilizada para referir-se a movimentos de negação da ordem e das autoridades estabelecidas - em último caso, da própria Coroa -, que resultaria em guerra e violência, a exemplo do caso francês, coexistia com uma concepção positiva, ligada à possibilidade de profundas transformações na ordem política e social em defesa de ideais relacionados à uma ideia de liberdade e de demais "direitos primordiais" do homem. Wasserman aponta que uma parte substancial desta última noção era dada pelo fato de "considerar a revolução como uma nova origem que deveria apagar todos os vestígios do passado colonial, convertendo-se além disso em uma inédita e eficaz fonte de legitimidade política que

\footnotetext{
${ }^{254}$ WASSERMAN, Fabio. Revolución. In.: GOLDMAN, Noemi. Lenguaje y revolución: conceptos politicos clave en el Rio de la Plata, 1780-1850. Buenos Aires: Prometeo Libros, 2008, p. 159-174.
} 
perduraria durante décadas". ${ }^{255} \mathrm{O}$ mesmo aconteceria em relação ao Brasil a partir da década de 1820. Após a declaração de sua independência política, a necessidade de consolidação de um "Império do Brasil” promoveria discursos legitimadores de uma revolução positiva, ou seja, sem os exageros das experiências de outros países. ${ }^{256}$

De outra parte, a caracterização da revolução como consequência esperada de um processo de desenvolvimento político das sociedades, regido por leis universais, também pode ser verificada em escritos da época. Wasserman destaca as publicações de Bernardo de Monteagudo no Censor de la Revolución que editava no Chile enquanto acompanhava José de San Martín. Sob o titulo "El siglo XIX y la Revolución”, Monteagudo teria traçado um panorama do "processo revolucionário" no mundo, assinalando que "a América espanhola não poderia subtrair-se ao influxo das leis gerais que traçam a marcha que devem seguir todo os corpos políticos, colocados em iguais circunstâncias". ${ }^{257}$ Nesta perspectiva, revolução era concebida como parte de um processo cujo curso extrapola as decisões e a consciência de seus protagonistas, contrariando assim um componente importante da primeira proposição - relacionado à luta pelo ideal de liberdade - que é a crença do processo como esforço do próprio homem.

$\mathrm{Na}$ esfera dos discursos esta contradição era atenuada situando a ação dos revolucionários como respostas que foram dadas durante o desenrolar da crise monárquica. Em outras ocasiões, o curso de uma revolução poderia ser divido em dois momentos distintos: o impulso revolucionário e a direção posterior que se dava ao movimento. Esta distinção permitiria, de forma generalizada, diferenciar o

\footnotetext{
${ }^{255}$ Ibidem, p. 162.

${ }^{256}$ PIMENTA, João Paulo Garrido. A independência do Brasil como uma revolução: história e atualidade de um tema clássico. In.: Revista digital História da Historiografia, n. ${ }^{\circ}$ 03, 2009, p. 53-82: http://www.ichs.ufop.br/rhh/index.php/revista/issue/current.

${ }^{257}$ Original de 30 de abril de 1820. MONTEAGUDO, Bernardo. Obras politicas. Buenos Aires: La Faculdad, 1916. Citado por WASSERMAN, Fabio. Revolución. In.: GOLDMAN, Noemi (ed.). Lenguaje y revolución, op. cit., p. 164.
} 
momento da crise que propiciou o início do processo de mudança na forma de governo, da luta pela independência e a construção de uma nova ordem. Assim, segundo Fabio Wasserman, “enquanto num primeiro momento primado pelos aspectos estruturais ou providenciais, no segundo, a ação humana teria maior incidência através da guerra e da ação política”. ${ }^{258}$

Portanto, nas primeiras décadas do XIX, o conceito de revolução incorporou novos sentidos com caráter ambíguo: por um lado, como emblema da liberdade e ação fundadora dos novos estados; por outro, causa de enfrentamentos que provocariam a degeneração desta própria revolução. Como exemplifica este trecho do Manifiesto del Congreso a los Pueblos, de 1816, publicado dias após a declaração de independência das Provincias Unidas del Río de la Plata:

\footnotetext{
"Queremos excusaros el disgusto de recorrer la serie odiosa de acaecimientos, que degradando el mérito de la revolución y el crédito de las gloriosas expediciones militares, nos ha reducido en las últimas derrotas a la situación más desolante". 259
}

No decreto publicado na sequência do referido manifesto, verifica-se o uso concomitante dos dois sentidos de revolução num mesmo escrito:

\footnotetext{
${ }^{258}$ Ibidem, p. 164-165.

${ }^{259}$ Manifesto del Congreso a los Pueblos, $1^{\circ}$ de agosto de 1816, p. 2. Buenos Aires: Imprenta de Gandarillas y Sócios, 1816. In.: http://books.google.com.br/books. Acessado em 18/01/2010.
} 
"Fin a la revolución, principio al orden, reconocimiento, obediencia y respeto á la autoridad de las províncias y pueblos representados en el congreso, y a sus determinaciones". ${ }^{260}$

Ou seja, a revolução que teria promovido a independência, num primeiro momento, deveria ser seguida da institucionalização da ordem para que os anseios de liberdade pudessem ser concretizados com a paz que seria alcançada com definição de regras e leis para a sociedade, pois, como anunciou o manifesto que antecede a publicação do dito decreto: "una resolución magnánima salva la pátria". ${ }^{261}$

Ideia correlata é apresentada no discurso de Simón Bolívar proferido na abertura do Congresso Geral da Venezuela, na cidade de Angostura, em fevereiro de 1819, quando se referiu ao "huracán revolucionario", e depositou nas mãos dos legisladores "el augusto deber de consagraros a la felicidad de la República", pois selariam os decretos pelos quais a Liberdade da Venezuela seria assegurada. E acrescentou que:

\begin{abstract}
“al pedir la estabilidad de los jueces, la creación de jurados, e un nuevo código, he pedido al Congreso la garantía de la libertad civil, la más preciosa, la más justa, la más necesaria, en una palabra la única libertad, pues que sin ella las demás son nulas". 262
\end{abstract}

Dessa maneira, nas primeiras décadas o século XIX, revolução ainda é, em todo o mundo ocidental incluindo a América ibérica, um conceito em construção, que

\footnotetext{
${ }^{260}$ Congreso en Tucuman, $1^{\circ}$ de agosto de 1816. Assinado por "Dr. José Ignácio Thames, presidente. Juan José Paso, diputado secretario". Buenos Aires: Imprenta de Gandarillas y Sócios, 1816. In.: http://books.google.com.br/books. Acessado em 18/01/2010 (grifo meu).

${ }^{261}$ Manifesto del Congreso a los Pueblos, $1^{\circ}$ de agosto de 1816, p. 30, op. cit.

262 "Discurso pronunciado por el General Bolívar al Congreso General de Venezuela en el acto de su instalación", em 15 de fevereiro de 1819. In.: Correo del Orinoco, n. ${ }^{\circ}$ 19, 20 de fevereiro de 1819, op. cit., p. 75-76.
} 
carrega um conjunto amplo de sentidos. Como assinala Javier Férnadez Sebastián, por sua própria natureza, os conceitos em política nunca são unívocos, pois estão sujeitos, em maior ou menor medida, à manipulação retórica e, neste trânsito entre o antigo e o novo, quase todas as noções políticas sofreram transformações num processo acelerado marcado pela instabilidade e antagonismos políticos, sendo submetidas a vários tipos de usos. ${ }^{263}$

Neste contexto, a observação dos espaços de comunicação impressa é fundamental para compreender como as sociedades ibero-americanas compreendiam os processos políticos em curso, e como compreendiam a si mesmas no decorrer de suas diferentes etapas. Sendo assim, a imprensa periódica converteu-se em fonte privilegiada de análise, uma vez que é receptáculo, motor de desenvolvimento e agente ativo das dinâmicas desse universo linguístico da política. Como veículo de projetos políticos, ela contribuía para o delineamento de identidades políticas e culturais, intervindo na dinâmica dos processos e episódios, em vez de simplesmente a reproduzi-los. $^{264}$

Portanto, o debate estabelecido entre o Correio Braziliense e o Correo del Orinoco - motivado pelos acontecimentos de 1817 em Pernambuco - está inserido em um contexto de rápidas transformações marcadas pela transitoriedade nas formas políticas em que é possível identificar ideias distintas relacionadas a revolução convivendo simultaneamente na esfera dos discursos e das práticas.

\footnotetext{
${ }^{263}$ FÉRNANDEZ SEBASTIÁN, Javier. Revolucionarios y liberales. Conceptos e identidades politicas en el mundo atlántico. In.: CALDERÓN, Maria Teresa; THIBAUD, Clément (org.). Las Revoluciones en el mundo atlántico, op. cit., p. 218.

${ }^{264}$ Marco MOREL; Mariana Monteiro BARROS. Palavra, imagem e poder, op. cit., p. 9.
} 


\section{2- Os termos do debate}

As primeiras informações sobre o movimento em Pernambuco, iniciado em 6 de março de 1817, foram noticiadas pelo Correio Braziliense dois meses depois desta data. Sua primeira menção foi feita através da reprodução de um extrato de uma correspondência inglesa sobre o ocorrido:

“A causa desta comoção se atribui ao universal descontentamento, que tem prevalecido por algum tempo entre as tropas e milícias, e entre o povo: nas tropas porque, não recebem seus soldos, nem meio algum de subsistência; e no povo, pelas pesadas contribuições e excessivas constrições, que se tem rigorosamente imposto, para a mediata conquista no Paraguai e Rio da Prata, no que o povo do Brasil não só não tem parte, mas julga contrária aos seus interesses". 265

$\mathrm{Na}$ sequência, num breve comentário, a relação entre os acontecimentos no Brasil e os movimentos na América hispânica foi, imediatamente, estabelecida. Hipólito da Costa previa que um movimento de contestação da ordem monárquica na América portuguesa provocaria um impacto relevante no convulsionado território hispano-americano - que evidentemente teria a causa republicana fortalecida:

"Se as notícias que temos recebido são corretas, e não temos duvida que o sejam, o Governo Português do Brasil se pode considerar totalmente subvertido, ao ponto de não haver esforços,

${ }^{265}$ Correio Braziliense n. ${ }^{\circ}$ 108, maio de 1817, op. cit., vol. 18, p. 552-553. 
que o possam restabelecer: e este acontecimento terá uma poderosa influência nas operações futuras dos insurgentes espanhóis". 266

Com a mesma concepção lógica de análise sobre os movimentos na América espanhola em 1810, considerados consequências políticas inevitáveis do mau governo de Espanha, ainda nesta publicação, o editor atribuiu os eventos em Pernambuco à má gestão do Estado português, usando o termo revolução para denominá-los:

"Quanto às causas do descontentamento do povo, os nossos leitores, que se lembrarem do que temos dito, sobre a necessidade de mudar a administração do Brasil, não acharão dificuldade em explicar a origem de tremenda revolução, que acaba de desenvolverse em Pernambuco; porque é moralmente impossível que um país como o Brasil, crescendo todos os dias em gente e, em civilização, ao ponto de constituir uma grande nação, possa sofrer a continuação do sistema de governo militar e, das instituições coloniais.

A comoção no Brasil é motivada por um descontentamento geral, e não por maquinações de alguns indivíduos, porque não há no Brasil indivíduos de influência bastante para regular a opinião pública. O descontentamento, que, pelas notícias que nos chegam de nossos correspondentes em toda a parte do Brasil, é muito geral, tem por causa a forma de administração militar, e por consequência despótica, que nunca põem em execução as ordens do governo, sem causar opressão aos povos; principalmente no recrutamento das tropas, e na cobrança dos direitos. (...)

${ }^{266}$ Ibdem, p. 555. 
Repetimos outra vez, porque o ponto é da maior importância, o descontentamento é geral, e generalíssimo, porque as suas causas abrangem a todos; logo o remédio único seria atalhar as suas causas, mudando a forma da Administração, como mil vezes temos recomendado, e o atestam as páginas do nosso Periódico". ${ }^{267}$

No número seguinte, no mês de junho, o Correio Braziliense publicou informações mais detalhadas sobre o ocorrido. Reproduziu duas cartas e o extrato de um jornal francês publicado pelo Jornal de acontecimentos na Bahia, que narrava os desdobramentos dos acontecimentos, ${ }^{268}$ além de reproduzir vários documentos - a "Ordem do dia do Capitão Geral de Pernambuco", o "Ultimatum dos patriotas ao Capitão Geral", uma "Resolução do conselho de Guerra", mais decretos e proclamações do Governo Provisório ${ }^{269}$-, para, na última seção do periódico, apresentar uma longa análise do editor sobre o dito movimento.

Parecendo desculpar-se por suas primeiras impressões, quando se referiu ao acontecido como "tremenda revolução", e que "o Governo Português do Brasil se [poder-se-ia] considerar totalmente subvertido, ao ponto de não haver esforços, que o

\footnotetext{
${ }^{267}$ Ibdem, p. 556-558 (itálico original e grifo meu). As matérias criticando a atuação do governo português no Brasil eram frequentes. Na publicação anterior (abril/1817), antes de qualquer notícia sobre o movimento pernambucano, publicou-se uma carta com pouco mais de quatro páginas sobre "os negócios públicos em Pernambuco", com duras críticas à administração daquela capitania. Ibdem, p. 466-470.

268 "Carta de um Braziliano, estabelecido em Londres, ao editor do Times, sobre a Nota das Potencias Aliadas ao Ministério do Rio de Janeiro"; "Narrativa da Revolução em Pernambuco por uma testemunha ocular"; e "Extraído das gazetas francesas - Nantes 5 de junho" [1817]. In.: Correio Braziliense n. ${ }^{\circ}$ 109, junho de 1817, op. cit., vol. 18, p. 646- 668.

269 "Decreto do Governo Provisório de Pernambuco, para aumentar o soldo das tropas", "Decreto do Governo Provisório de Pernambuco, abolindo vários impostos", "Decreto do Governo Provisório de Pernambuco, sobre a compra de armamentos", "Decreto do Governo Provisório de Pernambuco, ordenando o tractamento de vós", "Decreto do Governo Provisório de Pernambuco, fazendo entrar no Erário os rendimentos da Meza da Inspeção", "Decreto do Governo Provisório de Pernambuco, aggregando ao Erário a administração da extincta Companhia de Pernambuco", "Decreto do Governo Provisório de Pernambuco, confirmando o Cônsul Britannico", "Decreto do Governo Provisório de Pernambuco, para crear um corpo de cavallaria", "Proclamação do Governo Provisório de Pernambuco, mandando retirar a gente, que se oferecia a servir" e "Proclamação do Governo Provisório de Pernambuco, sobre a escravatura". In.: Correio Braziliense n. ${ }^{\circ}$ 109, junho de 1817, op. cit., vol. 18 , p. $600-617$.
} 
possam restabelecer”, Hipólito da Costa se colocou com a ansiedade diminuída pelas informações trazidas pelos vários documentos, e reduziu a importância do evento, igualando a situação pernambucana à de qualquer outra capitania do Brasil. Segundo o editor, as consequências do evento, e não as suas dimensões, seriam motivos para preocupações. O termo revolução passou a ser evitado - neste ponto a longa citação se faz necessária:

"A ansiedade, que sentimos, ao momento em que publicamos o número passado, tendo acabado de receber as notícias vagas e indeterminadas, sobre o levantamento de Pernambuco; se tem em grande parte diminuído; por termos podido de algum modo averiguar a extensão do mal; com os numerosos documentos, que nos chegaram à mão, depois da nossa última publicação. E sabemos que a insurreição se limita a Pernambuco, Paraíba e Rio Grande do Norte.

Este sucesso em Pernambuco é de muito maior importância em suas consequências, do que na sua atual extensão, e por isso julgamos muito conveniente publicar junto tudo quanto tem transpirado a este respeito; porque assim daremos a nosso leitores os meios de fazerem o seu juízo sobre os acontecimentos, e sobre as suas causas.

Em duas cartas que se publicaram nas gazetas inglesas, assinadas - "Um Braziliano estabelecido em Londres" - se insiste muito em que não há no Brasil causas de descontentamento. Nós deixamos copiada neste n. ${ }^{\circ}$ a p. 646 uma destas cartas; e a diante falaremos dela; mas aqui diremos, contra a opinião daquele escritor, que há em todo Brasil muita causa para descontentamento; e que se o governo não atender a isso com um remédio radical, quer subjugue 
quer não a presente insurreição em Pernambuco, continuará a ficar na borda do precipício. Isto são verdades amargas, mas não é com lisonjas que se induzem os Governos a obrar com acerto.

A p. 659 damos uma narrativa dos sucessos de Pernambuco, escrita por um sujeito que lá chegou; e não só pelo que ele ali escreve, mas por suas declarações verbais, sabemos que é decidido inimigo do Governo Provisório, estabelecido pelos insurgentes, e a demais, entretem princípios diametralmente opostos aos da revolução.

Não podemos, pois, vistas estas considerações, deixar de dar crédito às asserções desta testemunha ocular, quando descreve a administração em Pernambuco tão cheia de abusos, que até os olhos menos previdentes conheciam, que a máquina do governo estava caindo por si mesma.

Em um ponto certamente não concordamos com aquele escritor, e vem ser, que ele atribui a desorganização, que se observava em Pernambuco, à pessoa do Governador, quando nós muito decididamente a imputamos ao sistema. E a prova disso a achamos, no que sucede em todas as demais capitanias, e com todos os demais governadores, como se pode ver, pelas notícias, que temos de tempos em tempos publicado em nosso Periódico". 270

A correspondência publicada sob o título "Carta de um Braziliano, estabelecido em Londres" ao responder uma nota que aparentemente criticava o posicionamento do Governo português na América em relação às convulsões vizinhas - na parte Sul da fronteira entre Brasil e a América espanhola -, argumentava que:

${ }^{270}$ Ibdem, p. 671-680 (grifos meus). 
"aqueles que asseveram, que a revolução de Pernambuco, sucedida a 1.200 milhas de distancia foi excitada pelo exemplo da insurreição espanhola, devem conceder, que o governo do Brasil tinha, pelo menos, razão para temer o contato desta insurreição com a das províncias limítrofes; e qualquer que seja o resultado, eles não podem censurar por ter tomado todas as medidas, que estavam em seu poder, a fim de a remover". 271

Assim, podemos verificar que a relação dos eventos em Pernambuco com os movimentos republicanos na vizinhança hispânica era uma tendência na opinião pública da época, e não apenas parte do parecer do editor do Correio Braziliense. Este último, ao continuar sua análise, contradisse sua publicação anterior, pois desqualificou a iniciativa do movimento de Pernambuco e a escolha de um sistema republicano de governo. Neste ponto do discurso, Hipólito da Costa substituiu o termo revolução por rebelião e, seus protagonistas passaram a ser tratados como insurgentes:

"Desejamos porém aqui explicar-nos claramente, que esses abusos nunca podiam justificar uma rebelião; mas dizemos que são provocação mais que bastante. (...)

Uma vez que as revoluções começam pelo povo, a tendência é sempre para a forma de Governo Republicano; por mais imprópria que esta seja; por isso que as aparências de democracia são as que

\footnotetext{
271 "Carta de um Braziliano, estabelecido em Londres, ao editor do Times, sobre a Nota das Potencias Aliadas ao Ministério do Rio de Janeiro". In.: Correio Braziliense n. ${ }^{\circ}$ 109, junho de 1817, op. cit., vol. 18, p. 648 (grifos meus). O movimento eclodiu em Pernambuco no mesmo ano em que as tropas portuguesas conquistaram Montevidéu. Ver PIMENTA, João Paulo Garrido. O Brasil e a América Espanhola (1808-1822), op. cit., p. 238 et seq.
} 
mais lisonjeiam os indivíduos das classes mais numerosas. Assim, os insurgentes, em vez de seguirem o conselho de um de seus membros, que propunha mandar uma Deputação ao Soberano, resolveram logo declarar-se em Estado independente; publicaram o manifesto (à p. 604) aonde em vez de argumentos só usaram de inventivas diretas contra a pessoa do mesmo Soberano (...)". ${ }^{272}$

Dois meses depois, ao confirmar o controle monarquista na capitania, Hipólito da Costa, ao contrário do seu primeiro texto sobre o ocorrido em Pernambuco, deixou claro sua posição de reprovação à iniciativa:

"A narrativa oficial que publicamos, descreve o fim da tragédia em Pernambuco. Assim findou aquela criminosa e imprudente empresa, que na nossa opinião, como já dissemos, tenderá a demorar muito os melhoramentos necessários no Brasil, nas coisas políticas". 273

A adjetivação utilizada pelo editor nos revela, nesta etapa do discurso, uma concepção de revolução relacionada aos desdobramentos da experiência francesa na década de 1790 - principalmente depois da execução do rei em 1793 -, que vinculou o termo a um sentido negativo correspondente a convulsões sociais, anarquia, excessos e violência. Ou seja, de tudo o que poderia ser resumido pelo termo ‘tragédia' na redação de Hipólito da Costa.

Em fevereiro de 1819, mês em que se inaugurava o Congresso Geral da Venezuela, na cidade de Angostura - com o objetivo de elaborar uma Constituição

\footnotetext{
${ }^{272}$ Correio Braziliense n. ${ }^{\circ} 109$, junho de 1817, op. cit., vol. 18, p. 67 e 674 , respectivamente (grifo meu).

${ }^{273}$ Correio Braziliense n. ${ }^{\circ}$ 111, agosto de 1817, op. cit., vol. 10, p. 213 (grifos meus).
} 
que poria fim às instabilidades políticas do país ao organizar e institucionalizar o seu poder legislativo,$-{ }^{274}$ reconhecendo a importância do evento de 1817 em Pernambuco, o Correo del Orinoco, como veículo do movimento republicano na Venezuela, contestou as asserções do Correio Braziliense que, conforme vimos, após uma postura inicial compreensiva, passou a condená-lo enfaticamente. A refutação ao artigo de Hipólito da Costa, publicado em agosto de 1817, foi realizada num longo texto divido em três partes, publicadas a partir do n. ${ }^{\circ}$ 18, em 13 de fevereiro do referido ano, e continuada nas publicações n. ${ }^{\circ} 19$ e 22 - de 20 de fevereiro e 13 de março de 1819, respectivamente. Logo no início da primeira parte do artigo foi manifestada a surpresa em relação à oposição de Hipólito da Costa à dita revolução de Pernambuco:

"Si no tuviésemos a la vista el periódico impreso en Londres, no seriamos capaces de creer que el escritor incurriese en semejantes extravíos y inconsecuencias. Desde que comenzó nuestra revolución contra el despotismo religioso y político de España, tuvimos los

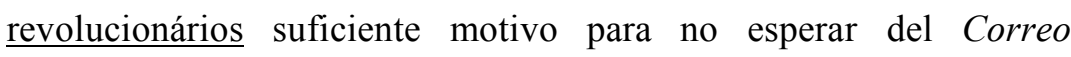
Braziliense una producción tal como la que indicamos. Desde entonces le apreciamos por sus ideas liberales, bien pronunciadas en los números que llegaban a nuestras manos sobre la regeneración política de este hemisferio.

Nos abstendremos de investigar cual haya sido la causa que indujo al Editor a contra-decirse en sus principios, vulnerando la alta

\footnotetext{
${ }^{274}$ Sobre Congresso de Angostura: HEBRARD, Véronique. La constitution d'Angostura: mise en pratique politique de l'expérience militaire. In.: Une nation par le discours: le Venezuela (1808-1830), Paris: l'Harmattan, 1997, p. 167-210.
} 
dignidad del hombre, hollando sus derechos imprescriptibles, y echando sobre sus escritos un borrón casi indeleble". ${ }^{275}$

O texto deixa claro que o autor do discurso publicado no periódico venezuelano já conhecia o trabalho de Hipólito da Costa, pois citava "los números que llegaban en nuestras manos", e, tudo indica que não foram poucos, pois argumenta que desde o início "de nuestra revolución", ou seja, do processo de distanciamento e separação da Venezuela em relação à Espanha, tiveram motivo suficiente para não esperar uma posição como esta que seria contestada. Além de assinalar a aparente contradição em relação à postura do editor do Correio Braziliense, o que deixaria "un borrón casi indeleble" sobre seus escritos.

Assim, comprova-se mais uma vez a amplitude dos espaços públicos de discussão política e a reciprocidade de interesses - entre a América espanhola, convulsionada e a caminho da formação de novas repúblicas, e a América portuguesa, que concentrava esforços para manutenção de um regime monarquista - expressa neste espaço que transpunha os limites dos Estados. Este fluxo de informações, protagonizado pela circulação da imprensa periódica, orientava em boa medida as ações dos respectivos agentes de governo. Em abril de 1819, o tenente português Pedro Miguel Ferreira Barreto, responsável pelo forte fronteiriço entre Brasil e Venezuela na região de Marabitenas, remeteu ao seu superior imediato, Manoel Joaquim do Paço - comandante da Capitania de São José do Rio Negro - seis periódicos recebidos diretamente do coronel republicano Juan José Leandro. Material com o qual manteve "bastante cautela, para que ninguém as lê-se, e não se

\footnotetext{
${ }^{275}$ Correo del Orinoco, n. ${ }^{\circ} 18,13$ de fevereiro de 1819, op. cit., p. 69 (grifos meus).
} 
persuadissem das fábulas e dos maus sistemas" contidas nas "ditas Gazetas”. ${ }^{276}$ Um ano e dois meses depois, "pelo motivo de há mais de seis meses não ter notícias das marchas, movimentos e direções dos ditos insurgentes”, Ferreira Barreto decidiu ir pessoalmente ao encontro do "correio insurgente" no posto de Cucuy. ${ }^{277}$

Retomando o discurso veiculado pelo Correo del Orinoco é importante destacar o uso do pronome possessivo "nossa" distinguindo a revolução na Venezuela de outros processos que podem receber a mesma denominação. Segundo Wasserman, este era um recurso comum utilizado para valorizar positivamente o movimento em questão, evitando a confusão da "nossa revolução" com outro tipo de movimento que pudesse ser considerado negativo. ${ }^{278}$ Como que depurando o vocabulário relacionado à revolução dos seus elementos mais subversivos, como o próprio termo, outro recurso era substituí-lo ou acompanha-lo por expressões como regeneração, reformas politicas, nova ordem, evitando assim a relação imediata com o indesejável processo francês.

Contudo, pouco tempo depois, no final do século XIX a fronteira semântica entre os termos revolução e reforma - ou restauração - estariam muito melhor definidas estabelecendo um contraste entre os termos, apresentado-os como pólos de uma dicotomia, ${ }^{279}$ quando o vocábulo revolução, no sentido político, passou a ser prioritariamente relacionado ao conceito do inédito.

$\mathrm{Na}$ continuação do discurso do Correo del Orinoco em poucas linhas, a proposta de refutação às ideias do Correio Braziliense sobre os acontecimentos de Pernambuco converteu-se em um discurso generalizado sobre o tema revolução:

\footnotetext{
${ }^{276}$ Pedro Miguel Ferreira Barreto a Manoel Joaquim do Paço. Forte Fronteiro de Marabitenas, $1^{\circ}$ de abril de 1819. In.: REIS, Arthur Cezar Ferreira, op. cit., p. 57.

${ }^{277}$ Pedro Miguel Ferreira Barreto a Manoel Joaquim do Paço. Forte Fronteiro de Marabitenas, 8 de junho de 1820. Ibdem, p. 83-84.

${ }^{278}$ WASSERMAN, Fabio. Revolución. In.: GOLDMAN, Noemi (ed.). Lenguaje y revolución, op. cit., p. $161-162$.

${ }^{279}$ FRANCISCO FUENTES, Juan; FERNÁNDEZ SEBASTIÁN, Javier. Revolución. In.: Diccionario político y social del siglo XIX espanhol. Madri: Alianza Editorial, 2002, p. 628-638.
} 
"Nada dice contra nuestra revolución el artículo que vitupera la de Pernambuco, pero siendo de una transcendencia universal los errores de derecho, alegados contra los agentes de esta novedad, también es del deber de todos los hombres libres atacarlos, sosteniendo los principios fundamentales de la sociedad, para que nunca puedan prevalecer contra el pacto social las invenciones que forman el tripe yugo de la monarquía absoluta, de los privilegios feudales, y del fanatismo religioso". 280

Para o autor do artigo, veiculado pelo periódico de Angostura, a revolução seria um direito natural do homem, posto que seria próprio de sua essência reagir à opressão, além de ser, supostamente, a única forma eficiente de luta contra as arbitrariedades dos governos tirânicos - a definição destes governos, em alguns trechos, parece confundir-se com a ideia de monarquia -, independente de tempo e espaço: "Por las revoluciones es que el hombre ha podido libertase de la tiranía, en todas las partes y en todos los tiempos". ${ }^{281}$

O sentido de revolução no discurso venezuelano nos parece evidente: um movimento positivo, benéfico e legítimo para a instauração de uma nova ordem, em nome da liberdade, direito inalienável do homem, e que teria como finalidade substituir um sistema despótico opressor. As motivações do Correo del Orinoco também são claras, pois como porta-voz do movimento pela independência da Venezuela, além de ferramenta de informação responsável por difundir uma imagem positiva dos resultados das ações das forças pró-independência, tinha o compromisso de disseminar entre os compatriotas os ideais e propósitos daquela revolução. Assim

\footnotetext{
${ }^{280}$ Correo del Orinoco, n. ${ }^{\circ} 18,13$ de fevereiro de 1819, op. cit., p. 69.
}

${ }^{281}$ Ibdem (grifo meu). 
como vincular seus esforços com movimentos similares, principalmente se em território contíguo à sua fronteira.

Em outro aspecto, precisava oferecer um contraponto aos ataques persistentes da Gaceta de Caracas, no período, convertida em instrumento realista de persuasão da opinião pública contra o movimento independentista. Dessa maneira, as notícias de um movimento análogo na resistente vizinhança monarquista do Brasil legitimariam ainda mais os empenhos republicanos na América hispânica - relação também estabelecida no universo lusitano dos discursos políticos como evidenciado pelo Correio Braziliense.

A circulação impressa, deste espaço no qual o debate estava inserido, possibilitou o conhecimento da refutação do periódico de Angostura por Hipólito da Costa. Dois meses depois da publicação da primeira parte da resposta elaborada pelo Correo do Orinoco, o Correio Brazilienze anunciou uma tréplica, em maio de 1819, estabelecendo um debate sobre o tema revolução - o longo discurso foi continuado nas dez edições seguintes, do números 133, de junho de 1819, ao 142, de março de 1820. Hipólito da Costa ao anunciar a contestação que pretendia, justificou a empreitada assinalando a importância do assunto naquela conjuntura política:

\footnotetext{
"Entre os números do Correo del Orinoco, que nesta ocasião recebemos, achamos nos de fevereiro uma forte impugnação do Correio Braziliense, que ocupava por vários dias a principal parte daquele Jornal. Tem por fim impugnar as doutrinas, que avançamos a respeito da última revolução de Pernambuco. No nosso n. ${ }^{\circ}$ seguinte diremos sobre isto o que convém, para nossa justificação, porque a
} 
matéria em si é demasiado importante, e seus resultados interessam à muitos milhões de pessoas". 282

No mês seguinte, ao iniciar efetivamente sua tréplica os motivos de Hipólito da Costa foram expostos de forma mais explícita:

\begin{abstract}
"Lamento que o Correo del Orinoco empreendesse combater doutrinas e opiniões, que nos atribui, sem citar as passagens que se propõe refutar; porque daqui resulta a dificuldade de fixar os pontos de controvérsia, em que não temos dúvida de entrar, e julgamos ser o nosso dever faze-lo: $1^{\circ}$ porque desejamos que nossas opiniões sejam claramente entendidas, naquela parte do mundo a que nosos escritos se destinam, assim como o Correo de Orinoco; $2^{\circ}$ porque as observações do Correo de Orinoco tem sido copiadas na Europa, onde vivemos, e não nos pode ser estranho o que se diz em jornais de reputação, e de extensa circulação, entre as pessoas que nos conhecem". ${ }^{283}$
\end{abstract}

Mais uma vez fica evidente a ampla extensão deste espaço de circulação de opiniões onde os discursos políticos travavam combates tão importantes quanto as batalhas armadas na tentativa de reordenar as realidades políticas em crise. O Correo del Orinoco e o Correio Braziliense participam deste mesmo espaço de interesses do mundo ocidental marcadamente pautado pelas experiências relacionadas a ideias de revolução. As expectativas geradas para o futuro a partir deste conjunto elaborado de experiências correspondem a projetos políticos distintos. Resta-nos verificar se as

\footnotetext{
${ }^{282}$ Correio Braziliense n. ${ }^{\circ} 132$, maio de 1819, op. cit., vol. 22, p. 539.

${ }^{283}$ Correio Braziliense n. ${ }^{\circ}$ 133, junho de 1819, op. cit., vol. 22, p. 614.
} 
concepções de revolução, utilizadas nos discursos que expressam estes projetos, são igualmente distintas.

$\mathrm{Na}$ resposta aos artigos do Correo del Orinoco, o editor do Correio Braziliense acusa o contendor de lhe atribuir o que nunca afirmou, "ou porque não entendeu, ou de propósito o viciou para ter ocasião, com o pretexto de nos refutar, de enviar ao Brasil este seu manifesto a favor das Revoluções”. Na sequência transcreve e responde contundentemente todo o discurso veiculado pelo Correo del Orinoco, trecho por trecho. Na contramão de seu discurso inicial, quando anunciou o ocorrido em Pernambuco - em março de 1817 -, Hipólito da Costa desvinculou os acontecimentos de Pernambuco do contexto vizinho:

"Bem diz este escritor, que, desde que começou a revolução da América espanhola, não publicou o Correio Braziliense coisa alguma, que fizesse dele esperar as doutrinas que nos imputam: mas isto devia fazer o escritor daquele artigo mais circunspecto, em não dar a nossas palavras sentido contrário aos sentimentos, que temos uniformemente sustentado, durante o longo período de nossa vida pública. Confundir o motim de $\underline{\text { Pernambuco }}$ com a revolução $\underline{\text { da }}$ América espanhola, é dar a conhecer grosseira ignorância dos fatos; e mostra grande falta de perspicácia, em distinguir as grandes revoluções dos motins populares, ou rebelião de soldados". 284

Assim, Hipólito da Costa reforçava a diferenciação do movimento iniciado em Pernambuco, classificando-o como rebelião, da iniciativa republicana na Venezuela, considerada uma revolução. Esta última seria justificada:

${ }^{284}$ Correio Braziliense n. ${ }^{\circ}$ 133, junho de 1819, op. cit., vol. 22, p. 616 (grifos meus). 
"O escritor confessa, que nada dizemos contra a revolução da América espanhola, quando falamos da de Pernambuco. Bastava isto para fazer ver, a não querer fechar os olhos de propósito, que nossos raciocínios sobre o motim de Pernambuco se fundavam em princípios locais, e que por outra parte não desejamos nem achamos justo argumentar com os sucessos da América espanhola, para pregar as revoluções em todo o mundo. Porque Caracas pode ter muito boas razões para sacudir o jogo de seu antigo governo, não se segue, que a Inglaterra, por exemplo, deva também destruir o seu governo atual. É isto uma confusão de ideias, de que é culpado o escritor do artigo; e que mostra a falácia de seus argumentos como depois veremos". 285

Dessa maneira, segundo o editor do Correio Braziliense, a justeza de uma iniciativa revolucionária residiria em suas causas, sendo um direito extraordinário, só justificável em casos extremos:

"A insurreição é a aniquilação de todo o direito rompendo por meio da força todos os vínculos entre povo e governo; e se isto é um direito ordinário não pode jamais existir um vínculo permanente na sociedade. Se jamais existe o direito de entrar em insurreição, este direito, longe de ser ordinário, deve ser tão extraordinário, que só pode ter lugar naquele caso extremo, em que é preciso romper todo o direito e recorrer à força". ${ }^{286}$

\footnotetext{
${ }^{285}$ Correio Braziliense n. ${ }^{\circ}$ 133, junho de 1819, op. cit., vol. 22, p. 617.
}

${ }^{286}$ Correio Braziliense $\mathrm{n}^{\mathrm{o}}$ 133, junho de 1819, op. cit., vol. 22, p. 624. 
A argumentação, neste ponto, considera o termo insurreição sinônimo de revolução, relacionando-o a condições negativas de "aniquilação de todo direito", “caso extremo", de uso da força, mais uma vez revelando uma concepção do termo revolução relacionada à negação da ordem nos moldes do quadro francês da última década do século anterior. Esta faceta do processo de construção do conceito revolução, é tão moderna quanto a ideia de defesa dos princípios de liberdade e demais direitos do homem. A primeira, como consequência indesejada, e a segunda como causa nobre motivadora do processo.

Nesta lógica, a necessidade de desvincular os acontecimentos de Pernambuco, parte integrante de uma monarquia, do contexto vizinho, que seguia num processo dito revolucionário em direção da formação de Estados republicanos, é evidente. Qualificando o movimento de Pernambuco como "motim isolado", sem comparação, portanto, aos movimentos na América espanhola, assinalando a diferença de sua situação comparada aos países vizinhos, pois, Pernambuco tinha um rei "de posse pacífica, sem contendor rival" e "longe de sofrer opressões e vexames (...) passava por ser a mais rica praça de comércio do Brasil", ${ }^{287}$ não teria, assim, motivos para rebelar-se. Portanto, um texto que correspondia à sabida importância da discussão de tal tema na esfera pública, seja pela necessidade da defesa de um projeto político junto à opinião pública, ou ainda por uma questão mais ampla, pois como apontado anos antes pelo próprio Hipólito da Costa:

"porque esses jornais formam a história do tempo; estes fatos são depois transferidos para os registros anuais, e daí copiam os

\footnotetext{
${ }^{287}$ Correio Braziliense $\mathrm{n}^{\circ}$ 135, agosto de 1819, op. cit., vol. 23, p. 171-173.
} 
historiadores para as histórias que serão transmitidas à posteridade; e assim se estabelece o bom ou mau nome de uma nação". 288

Neste ponto, para compreensão do debate, é imprescindível investigar o sentido da aparente mudança de tom de Hipólito da Costa sobre o tema revolução após os eventos de Pernambuco, pois, como apontado por Pimenta, parece que a equação entre ideias e discursos deixa de funcionar na orientação das publicações do Correio Braziliense. ${ }^{289}$ Para tanto, voltemos às repercussões dos movimentos hispanoamericanos de 1810 .

A posição de Hipólito da Costa relacionada à constituição das Juntas de Governos na América espanhola, em 1810, justificava as iniciativas em razão da má administração da metrópole, como já indicado:

“A impossibilidade de governar bem províncias tão distantes, e tão extensas, como são as da América do Sul, relativamente à Metrópole na Europa, é uma verdade que tem sido reconhecida em todos os tempos; e olhando para o péssimo sistema de Governo que a Espanha adotou para as suas colônias, que não era nem mais nem menos do que um despotismo militar; a admiração é que as ligações entre a Metrópole, e as colônias, pudessem existir até agora". ${ }^{290}$

\footnotetext{
288 Correio Braziliense, 1808. Citado por PIMENTA, João Paulo Garrido. A política hispanoamericana e o império português (1810-1817): vocabulário político e conjuntura. In.: JANCSÓ, István (org.). Brasil: formação do Estado e da nação, op. cit., p.123.

289 BERBEL, Márcia Regina. Pátria e patriotas em Pernambuco (1817-1822) nação, identidade e vocabulário político. In.: JANCSÓ, István (org.). Brasil: formação do Estado e da nação, op. cit., p. 345-364.

${ }^{290}$ Correio Braziliense n. ${ }^{\circ}$ 28, setembro de 1810, op. cit., vol. 5, p. 352-353.
} 
Não se trata de um apoio explícito do editor a hipóteses de movimentos que levariam às independências na América espanhola. Pelo contrário. É importante lembrar a condição de monarquista de Hipólito da Costa, convicto da necessidade de reforma em torno da monarquia Bragantina como meio de garantir a integridade do Império português. Assim, seu discurso se insere na lógica do reformismo ilustrado setecentista, cujo objetivo era a eficiência e a racionalidade do Estado a serem obtidas por meio da transformação de sua gestão política. Os eventos hispano-americanos de começos do século XIX serviriam como exemplo da necessidade destas reformas. ${ }^{291}$ Poderiam representar uma lição ao governo português, frequentemente criticado pelo Correio Braziliense. Contudo, deve-se salientar a distinção feita entre os responsáveis pela administração lusitana e o Príncipe Regente, sempre poupado pelo periódico. Em alguns trechos, como neste de novembro de 1814, explicitamente:

\footnotetext{
"Desaprovando a forma de administração das províncias do Brasil; explicando por fatos individuais, que nos chegam à notícia, as razões porque desaprovamos aquele Governo; estamos tão longe de acusarmos o Soberano, que até nem aos mesmos Governadores e Magistrados, de quem nos queixamos, atribuímos a causa principal dos desgovernos, que desejamos ver remediados". 292
}

Outro exemplo encontrado está na edição de março de 1816, quando a propósito da efetivação da unidade da administração do Reino Unido de Portugal, Brasil e Algarves, Hipólito da Costa afirmou:

\footnotetext{
${ }^{291}$ Sobre a identidade política de Hipólito da Costa ver p. 26.

${ }^{292}$ Correio Braziliense n. ${ }^{\circ}$ 78, novembro de 1814, op. cit., vol. 13, p. 710.
} 
"O plano para pôr em pratica estas ideias pertence aos Ministros de Estado, que são pagos pelo Soberano para isto; e portanto, contra eles deve clamar a nação, se o não fazem". 293

Voltando aos eventos de 1817 em Pernambuco, como vimos, momento crítico para administração portuguesa no Brasil, o editor do Correio Braziliense sentenciou:

"El Rei, como naturalmente acontece a quase todos os Príncipes, não tem quem lhe fale a verdade; e assim não temos dúvida que esta revolução de Pernambuco lhe será representada como mera ebulição do momento (...)". ${ }^{294}$

Assim, é importante considerar a figura do Rei no discurso do editor do Correio Braziliense, posto que é um monarquista. Ao apoiar as manifestações de 1810 que, aos seus olhos, começavam a desvincular as colônias americanas do poder metropolitano espanhol, o primeiro argumento utilizado se referia à ausência do soberano:

"A justiça deste modo de proceder nos parece evidente; porque não há mais razão para supor que a província de Caracas ou outra qualquer da América espanhola se deva submeter ao governo da província de Galiza, ou de Andaluzia ou de outra qualquer província europeia; (...) pois é evidente que faltando o Soberano a nação devia escolher um Governo; (...)". 295

\footnotetext{
${ }^{293}$ Correio Braziliense n. ${ }^{\circ}$ 94, março de 1816, op. cit., vol. 16, p. 296.

${ }^{294}$ Correio Braziliense n. ${ }^{\circ}$ 108, maio de 1817, op. cit., vol. 18, p. 557.

${ }^{295}$ Correio Braziliense n. ${ }^{\circ}$ 25, junho de 1810, op. cit., vol. 4, p. 663.
} 
Em setembro do mesmo ano, afirmou:
"Por consequência espontânea, tornou as Américas emancipadas; bem como o filho pela morte de seu pai se acha naturalmente sui juris. A Espanha com a prisão de seus Monarcas, e família Real ficou em estado de anarquia (...)". 296

Destarte, nos parece coerente quando o editor distancia os acontecimentos de 1817 dos movimentos hispano-americanos utilizando como principal argumento a presença, na América, do Príncipe Regente português, pois, como já assinalado em sua tréplica ao Correo del Orinoco, uma revolução seria justificada por uma causa extrema. Assim, os protagonistas do movimento de Pernambuco não teriam um motivo justo para se rebelarem, ao contrário dos vizinhos hispânicos que precisavam responder à crise instaurada pela ação napoleônica em território metropolitano:

\begin{abstract}
"Em Pernambuco havia um rei só de posse pacífica, sem contendor ou rival (...). não havia rei intruso ou estrangeiro; era o mesmo que tinha sempre ali governado; Pernambuco, longe de sofrer opressões e vexames; que o fizessem mais humilde do que outras províncias, passava por ser a mais rica praça de comércio do Brasil”. 297
\end{abstract}

Contudo, perceber nos escritos de Hipólito da Costa os motivos de distinção entre os eventos de Pernambuco em 1817 e as movimentações na América espanhola não resolve a questão sobre a sua mudança posicionamento em relação ao tema. Aspecto relevante uma vez que nos permite vislumbrar a história de mutações

\footnotetext{
${ }^{296}$ Correio Braziliense n. ${ }^{\circ}$ 28, setembro de 1810, op. cit., vol. 5, p. 355.

${ }^{297}$ Correio Braziliense ${ }^{\circ}{ }^{135}$, agosto de 1819, op. cit., vol. 23, p. 171-173.
} 
políticas da maior importância, subjacentes ao tema revolução tal qual tratado a época.

Dessa maneira, devemos considerar que a lógica do discurso monarquista veiculado pelo Correio Braziliense sobre as revoluções da América hispânica era norteada pela ausência do rei, de modo que se faz necessário verificar as orientações das publicações deste periódico após o retorno de Fernando VII ao trono, em 1814. A primeira nota sobre o assunto foi publicada em janeiro daquele ano, quando Hipólito da Costa assinalou que deveria ser notado "o importante fato de se haver concluído um tratado entre Fernando VII e Napoleão Bonaparte, para o fim de restituir à Espanha o seu legítimo soberano". ${ }^{298}$ O discurso sobre a justiça da restituição do trono ao rei espanhol foi reforçado no número seguinte:

"Quanto às protestações de lealdade dos espanhóis, e sua prometida obediência a Fernando VII, quando ele voltar para a Espanha; nada pode ser mais próprio, conveniente, e justo; mas aconteceu sobre isto um incidente mui notável.

Na sessão das Cortes de 3 de fevereiro, o deputado de Sevilha, La Reyna, declarou, que logo que chegasse Fernando VII a Espanha, se deveria reconhecer, que este Soberano tinha nascido com o direito e poder de governar a Espanha despótica, e absolutamente; e que consequentemente a nova Constituição se deveria declarar nula e inválida". 299

A ideia do deputado La Reyna, que parecia improvável, qualificada por Hipólito da Costa como "incidente", confirmou-se, três meses depois, com dissolução

${ }^{298}$ Correio Braziliense ${ }^{0}$ 68, janeiro de 1814, op. cit., vol. 12, p. 143.

${ }^{299}$ Correio Braziliense $\mathrm{n}^{\circ}$ 69, fevereiro de 1814, op. cit., vol. 12, p. 305-306. 
das Cortes e revogação da Constituição de Cádiz pelo monarca espanhol. Ainda assim, este ato de Fernando VII poderia ser justificado por uma possível tentativa de corrigir os equívocos do governo:

"El Rey publicou um decreto, em data de Valencia, aos 4 de Maio pelo qual mandou dissolver as Cortes, e declarou a sua intenção de não admitir a Constituição; e o que mais é, parece fazer responsáveis aos membros das Cortes pelo que tem obrado, e os ameaça com as penas de traidores. Nos julgamos que S. M. não enumera no número das traições, o terem as Cortes recuperado o Reino, que ele tinha entregado ao Franceses; se a isto se chama traição, é nomenclatura sem exemplo.

Não há dúvida de que a Constituição de Espanha tem defeitos consideráveis, e talvez as objeções d'El Rey sejam tendentes a uma reforma útil; mas por hora não se sabe em que consiste a dificuldade. Desde que vimos a Constituição da Espanha notamos a incongruência de atribuírem às Cortes a si o tratamento de Majestade, ao mesmo tempo em que admitiam um Rei, de se intrometerem com objetos do Poder Executivo, quando somente asseverava competir-lhe o poder legislativo; \&c, \&c. Portanto se as objeções d'El Rei se dirigem a tais pontos, não podemos deixar de dizer que são bem fundadas". 300

Portanto, o editor português preservava o soberano espanhol, tentando justificar os equívocos de seus atos pelo mau trabalho dos Conselheiros à sua volta,

\footnotetext{
${ }^{300}$ Correio Braziliense n. ${ }^{\circ}$ 72, maio de 1814, op. cit., vol. 12, p. 761.
} 
reafirmando, de modo coerente, suas convicções legitimistas, expressas em ferramentas discursivas claras:

"Os Conselheiros de Carlos IV e de Fernando VII, principalmente deste último, entregaram as fortalezas que eram as chaves da Espanha, a seus inimigos, permitiram a entrada das tropas invasoras até a capital sem a menor resistência deram a Bonaparte a espada de Francisco I; que era um monumento inestimável do valor dos Espanhóis , entregaram toda a Família Real nas mãos dos inimigos da Espanha, deixando assim a nação no mais horroroso estado de anarquia. Desses Cortesãos, uns seguiram o partido do inimigo, outros covardemente desertaram e fugiram.

¿E é a tal gente que os patriotas das Cortes devem tornar a dar um poder ilimitado e sujeitar-se de novo às desgraças que lhes poderá ocasionar algum novo Godoy?". 301

Na edição seguinte, em maio de 1814, na introdução de um artigo no qual apresentou de forma mais elaborada os motivos de sua reprovação ao governo espanhol, Hipólito da Costa justificou:

“O leitor achará a p. 774 a proclamação de Fernando VII em que S. M. manda dissolver a Regência, e as Cortes, declara nulos os seus atos; e explica as razões, e motivos de seu comportamento. (...)

Desaprovando, como fazemos em grande parte, estes procedimentos na Espanha, estamos bem longe de imputar as ações, que nos parecem erradas, à pessoa de Fernando; o que somente

\footnotetext{
${ }^{301}$ Correio Braziliense n. ${ }^{\circ}$ 72, maio de 1814, op. cit., vol. 12, p. 761.
} 
faríamos, e não hesitaremos em o fazer, se disso tivermos provas; a presunção porém está a seu favor; porque ausente da Espanha por sete anos, é impossível que possa saber qual é o presente estado das cousas, a opinião dos espanhóis, nem o modo de pensar da Europa inteira. Apenas entrou na Espanha e viu-se cercado de aduladores, de inimigos das Cortes e partidários Franceses; alguns tumultos populares, e vozerias contra as Cortes, foram apresentados como a voz da nação; e em tais circunstancias é da maior dificuldade que Fernando VII possa conhecer, ou decidir por si cousa alguma; é por isto que julgamos os seus conselheiros pessoas principais, e objeto de nossa censura nas observações que vamos fazer". ${ }^{302}$

Nas edições subsequentes do Correio Braziliense, Hipólito da Costa continuou publicando documentos oficiais do governo espanhol, criticando suas medidas, apontando a desaprovação da opinião pública internacional e o descontentamento dos súditos. Os principais motivos de críticas à administração espanhola apontados eram o restabelecimento dos jesuítas, da Inquisição, dos monopólios, as perseguições políticas e a censura à imprensa:

"Parece claro, que os Godoyanos, a quem Fernando VII deveu o seu cativeiro, e a Espanha as suas desgraças, são agora os que governam. A Inquisição, os Jesuítas, o antigo sistema dos monopólios, o arranjo da corrupção nas finanças, constituem a base das medidas políticas daquele governo, que ainda assim não abre os olhos, e intenta enganar o mundo enganando-se a si mesmo, negando a existência do descontentamento geral da Nação.

${ }^{302}$ Correio Braziliense n. ${ }^{\text {7 }}$ 73, junho de 1814, op. cit., vol. 12, p. 919-920. 
Deixando a questão se o governo de Espanha poderá ou não conquistar os rebeldes, e forçar ao silêncio, por meio das armas, a multidão de seus descontentes; ainda que o consiga ¿Quão triste não é a consideração de reinar um monarca legítimo, pelos mesmos meios de que usou o usurpador, a quem os patriotas espanhóis expulsaram do Reino?". 303

Verificamos, nas críticas subsequentes ao recrudescimento da política despótica na Espanha, uma tendência do editor do Correio Braziliense de responsabilizar o rei espanhol de não ver o óbvio, intentando "enganar o mundo enganando-se a si mesmo, negando a existência do descontentamento geral da Nação" ${ }^{304}$ No decorrer do ano seguinte esta tendência se confirmou e evoluiu a ponto de tornarem-se acusações contra o Fernando VII:

“A confusão que se observa naquele país, não admira a ninguém, depois das medidas, que tem praticado Fernando VII, desde que tornou a entrar em Espanha. As prisões arbitrárias, a falta de energia na nação; a ruína das rendas públicas, e sobretudo o estado de suas colônias, são claras provas de que o governo vai errado". 305

Sem perspectiva de mudança na orientação política espanhola, as críticas se tornaram mais contundentes ainda. Em janeiro de 1815, Hipólito da Costa afirmou:

"Nós faltaríamos ao nosso dever, como jornalista, se não declarássemos abertamente a nossa opinião, nesta importante

\footnotetext{
${ }^{303}$ Correio Braziliense n. ${ }^{\text {o } 77}$, outubro de 1814, op. cit., vol. 13, p. 555.

${ }^{304}$ Ibdem.

${ }^{305}$ Correio Braziliense n. ${ }^{\circ}$ 80, janeiro de 1815, op. cit., vol. 14, p. 131.
} 
matéria. Fernando VII é guiado em sua política por princípios radicalmente maus. Reina vivendo ainda seu Pai; cuja abdicação em Madri declarou nula; e cuja renuncia, em Bayona, é, pelo menos tão ilegal, quanto o foi a de Fernando VII. Os elementos, que formam as máximas políticas d'El Rei, são os mais opostos a qualquer reforma como mostrou pela renovação da Inquisição, introdução dos Jesuítas, supressão total da imprensa; e abandono geral de todos aqueles que contribuíram para reconquistar-lhe a coroa". ${ }^{306}$

Mais uma vez considerando uma lógica do reformismo ilustrado - a que se baseava na mudança racional da gestão pública para ganho de eficiência do Estado - a incorreção da política de Fernando VII justificaria não só a situação de descontentamento dos súditos espanhóis na península, como também da situação de sublevação de suas colônias na América, consequência política natural da má gestão do Estado. Como vimos anteriormente, este modo de considerar a política colonial espanhola era aplicado também à administração portuguesa, frequentemente criticada pelo editor do Correio Braziliense; contudo, nunca levada ao extremo de justificar qualquer ação de negação à soberania do monarca, como a que seria levada a cabo em Pernambuco em 1817. Nessa ocasião, continuando a resposta às proposições do Correo del Orinoco, Hipólito da Costa afirmou: "na monarquia, o monarca é soberano, se não o é, deixa o governo de ser monárquico (..), não pode o monarca ser soberano, e o povo ser também soberano". 307

No caso espanhol, a privação do rei teria criado uma situação de crise que só teria sido agravada pela ausência de iniciativas na direção das reformas necessárias, após o retorno de Fernando VII ao trono. A velocidade das transformações e o

\footnotetext{
${ }^{306}$ Correio Braziliense n. ${ }^{\circ} 89$, novembro de 1815, op. cit., vol. 15, p. 560.

${ }^{307}$ Correio Braziliense n. ${ }^{\circ}$ 134, julho de 1819, op. cit., vol. 23, p. 46.
} 
prolongamento da guerra em território americano teriam determinado o futuro da América hispânica independente da ação do monarca, que segundo Hipólito da Costa, só "fazia continuar o que estava começado". ${ }^{308}$ Já em 1814, apesar de significativas vitórias realistas em território americano, o Correio Braziliense fazia um diagnóstico preciso da situação desfavorável à causa da coroa espanhola:

"Quanto as Colônias, o governo de Espanha nem tem tempo de atender a elas, nem meios de as subjugar por força, nem assaz juízo e prudência para as conciliar por bons modos. A guerra civil continua no Rio da Prata, e em Caracas, sem intermissão; os sucessos têm sido vários de parte a parte, mas a sua longa duração é decididamente contra a Espanha; porque quanto mais se prolongar, mais se acostumarão os povos da América a viver independentes da Espanha, mais se instruirão na arte da guerra, e mais consolidarão a opinião do povo, como esse novo tal qual governo que tem; pelo contrário a Espanha com a continuação daquela guerra vai perdendo gente, diminuindo os recursos pecuniários, abatendo o crédito e influência que deve ter nos espíritos dos povos, e sem o que é moralmente impossível conte-los em sujeição". ${ }^{309}$

Um ano depois, a independência política dos territórios hispano-americanos já era dada como certa, apesar do retorno de Fernando VII:

"Quanto as Colônias de Espanha, temos recebido muitas noticias de varias partes; e todas elas convém, em que as pequenas forças, que o

\footnotetext{
${ }^{308}$ Correio Braziliense n. ${ }^{\circ}$ 94, março de 1816, op. cit., vol. 16, p. 305.

${ }^{309}$ Correio Braziliense n. ${ }^{\circ}$ 75, agosto de 1814, op. cit., vol. 13, p. 274.
} 
Rei de Espanha para ali tem mandado, só servem de conservar o fogo da guerra civil, sem que por forma nenhuma sejam adequadas para submeter os partidos; assim, a desolação, e ruína geral, são os únicos resultados desta disputa na América, de cujo êxito já ninguém duvida". 310

Com isto, Hipólito da Costa explicava, e até mesmo justificava, a situação na América espanhola, o que não significa que concordasse com a ideia de que uma revolução fosse uma solução política adequada para situação de crise. Em outubro de 1815, ainda versando sobre os acontecimentos na vizinhança do Brasil, o editor do Correio Braziliense se referiu à “efusão de sangue, que o terrível meio de uma revolução, e consequente guerra civil deve trazer consigo". ${ }^{311}$ Em suas reflexões sobre a experiência de Pernambuco em 1817 colocou:

“(...) pela experiência que a história nos ensina, é claro ser da natureza humana, que, quando em uma nação faltam os meios constitucionais de poderem os povos representar as suas queixas ao Imperante, sempre apelam, com direito ou sem ele, para o meios da força: e por fim se vê o Governo obrigado a declarar guerra contra seus súditos, de onde se seguem todas as misérias e desgraças, concomitantes das guerras civis.

Por todas as notícias que temos parece que estas foram as causas remotas da insurreição de Pernambuco; e a causa próxima foi um rumor, que se levantou, sem o menor fundamento, de que havia

\footnotetext{
${ }^{310}$ Correio Braziliense n. ${ }^{\circ} 88$, setembro de 1815, op. cit., vol. 15, p. 393.

${ }^{311}$ Correio Braziliense n. ${ }^{\circ}$ 89, outubro de 1815, op. cit., vol. 15, p. 560.
} 
entre os habitantes daquela cidade certa rivalidade e ódio dos portugueses europeus, com os portugueses brazilianos". 312

Assim, sobre o ocorrido em Pernambuco no ano de 1817, Hipólito da Costa reiterava sua posição, ao afirmar, de modo definitivo, "que é absurdo quem supõe, que as revoluções são o meio de melhorar a nação". A república, consequência da revolução, seria também reprovada, pois "uma vez que as revoluções começam pelo povo, a tendência é sempre para a forma de Governo Republicano; por mais imprópria que esta seja".313

Os discursos veiculados pelo Correio Braziliense justificavam uma revolução como consequência esperada a um quadro negativo extremo causado pela ineficiência e incorreção da administração estatal, mas que não a aprovava enquanto solução política, pelo contrário, apresentava-a como mal que poderia ser evitado por reformas administrativas adequadas. Dessa maneira, o quadro apresentado permite afirmar que a contradição à postura editorial do Correio Braziliense no tocante a relação dos eventos da convulsionada América hispânica com o Brasil reside no anúncio do ocorrido em Pernambuco, tal qual na primeira vez em que o movimento foi citado, pois em nenhuma outra passagem de qualquer outra edição do periódico, entre os anos de 1810 e 1819, essa comparação foi claramente formulada a propósito de um evento sedicioso. Claro que as análises anteriores dos casos hispano-americanos, consequência de uma má gestão metropolitana, poderiam ser lidas como exemplo para que a administração portuguesa não chegasse a tal situação de crise, mas esta relação não chegou a ser explicitada por Hipólito da Costa antes da edição de maio de 1817 e, nem depois dela. A manutenção da monarquia bragantina, ao contrário do que

\footnotetext{
${ }^{312}$ Correio Braziliense n. ${ }^{\circ}$ 109, junho de 1817, op. cit., vol. 18, p. 673.

${ }^{313}$ Ibdem, p. 671-680.
} 
ocorrera no caso espanhol, realmente deixava a aparência de que as dificuldades enfrentadas pela administração portuguesa não seriam comparáveis à crise instaurada no mundo hispânico a partir da privação do rei, crise esta, que tamanha, não teria solução possível após seu retorno. Tal aparência que os homens empenhados na causa monarquista precisavam manter a todo custo nos domínios de sua majestade, e mesmo fora deles - pois os discursos veiculados no amplo espaço público de discussão política do mundo ocidental, enquanto forma de legitimação, eram elemento de grande importância nas determinações dos homens que protagonizavam a dificílima gestão política daqueles tempos.

O contexto linguístico no qual estava inserido o discurso do Correio Braziliense, relacionava revolução, no sentido político, diretamente aos exageros dos episódios franceses, ou seja, um termo marcado pelo estigma da violência. Na América espanhola, o quadro não seria fundamentalmente diferente, pois a desolação provocada pela guerra era evidente aos protagonistas e contemporâneos. A língua portuguesa em 1813 já havia lexicografado um sentido político para o verbete revolução como "mudanças na forma e política" nos Estados. No mundo hispânico, verifica-se registro muito anterior: o Diccionario de Autoridades, o primeiro dicionário da língua castelhana publicada pela Real Academia Espanhola entre 1726 e 1739, já registrava duas acepções políticas do termo revolução que omite qualquer referência cíclica. A primeira com o sentido de "inquietud, alboroto, sedición, alteración", e a segunda, "novedad radical".314

Nesta conjuntura, a ideia de revolução podia ser concebida como uma conspiração não só contra o trono, mas também contra a sociedade civil, tramada com ideais jacobinos, "formada a partir de seitas há muito tempo escondidas nas lojas

\footnotetext{
314 SILVA, Antonio Moraes. Diccionario da lingua portugueza, op. cit., p. 629; FRANCISCO FUENTES, Juan; FERNÁNDEZ SEBASTIÁN, Javier. Revolución. In.: Diccionario político y social del siglo XIX espanhol. Madri: Alianza Editorial, 2002, p. 628, respectivamente.
} 
maçônicas como fez o abbé Barruel, cujas ideias não tardaram a circular em Portugal e cuja principal obra teve trechos traduzidos para o português no momento das invasões napoleônicas. Eram textos escritos numa linguagem exacerbada, em que formulavam impropérios contra todo o mundo misterioso de ideias revolucionárias, de formas ocultas e condenadas". ${ }^{315}$ A percepção da Revolução Francesa como um radicalismo violento continuava a povoar o imaginário político das elites lusitanas, dos dois lados do Atlântico, nos anos seguintes a crise instaurada pela "Revolução francesa", pois era vista como continuada pelas investidas de Napoleão Bonaparte. Dessa maneira, procurou-se sempre evitar o uso do termo indesejável. Contudo, a proximidade das convulsões hispano-americanas e o acesso às suas publicações tornavam tal tarefa cada vez mais árdua.

Quando das primeiras reações contra as investidas napoleônicas em Portugal, iniciadas em junho de 1808, contando com ampla participação popular, usou-se a denominação "Restauração portuguesa". Nos escritos da época, principalmente os panfletos políticos, a linguagem predominante relacionava o movimento em Portugal à restituição da liberdade a cidadãos que gozavam da "felicidade de serem regidos por leis tutelares e protetoras, que formam a base de um Governo suave e legítimo, de um Príncipe Justo e Piedoso", opondo-se em todos os sentidos às praticas da Revolução Francesa, relacionadas à degeneração, vícios e crimes. ${ }^{316}$

Nesta lógica, reitera-se o que foi demonstrado por Pimenta, em relação à documentação diplomática portuguesa do período: revolução, sublevação e guerras civis, são os vocábulos dominantes nas manifestações verbais que procuram qualificar os acontecimentos hispano-americanos de 1810, também associados à anarquia,

\footnotetext{
${ }^{315}$ NEVES, Lúcia Maria Bastos P.. Revolução em busca do conceito no império luso-brasileiro (17991822). In.: FERES Júnior, João; JASMÍN, Marcelo (Org.). História dos Conceitos. Diálogos transatlânticos. Rio de Janeiro: Editora PUC Rio, Loyola, IUPERJ, 2007, p. 132.

${ }^{316}$ Ibdem, p. 132-133.
} 
ideias jacobinas, insubordinação, rebelião, república e revolta ${ }^{317}$ Ou seja, um quadro linguístico que no começo da década continuava a igualar o termo revolução a outros relacionados à ação contra o legítimo soberano. ${ }^{318}$ Quadro este completamente justificado pelos temores dos homens de Estado português na condição de condutores diretos de uma ordem política que, acreditava-se, poderia ser ameaçada pela turbulência vizinha.

$\mathrm{Na}$ Espanha, a partir de 1808, o vocábulo revolução foi parcialmente resignificado, sendo relacionado a uma ideia de patriotismo relacionada aos esforços e sacrifícios dos espanhóis contra o invasor francês; enquanto que anarquia era uma das palavras utilizadas para se referir a todos os aspectos negativos e anti-sociais que o processo pudesse conter. ${ }^{319}$ Contudo, ainda que a motivação das iniciativas na Espanha fosse salvaguardar a ordem monárquica alterada - mesmo que uma parcela deste movimento tenha se aproveitado das circunstâncias para transformar uma ordem social regida pelo tradicionalismo absolutista em uma sociedade dotada de um regime constitucional representativo, ou seja, com o poder político limitado por alguns direitos e liberdades dos indivíduos -, a alteração relativamente radical de governo implicava associação a distúrbios, sedições, alteração violenta da ordem e eventualmente até guerra civil. Assim, alguns textos propuseram o uso do termo renovação, como sendo o mais adequado para descrição do caso espanhol. ${ }^{320}$

Em uma proclamação de 1808 da Junta Central de Espanha, afirmou-se "que a revolução espanhola" teria "características inteiramente diversas das que se haviam

\footnotetext{
${ }^{317}$ PIMENTA, João Paulo Garrido. A política hispano-americana e o império português (1810-1817): vocabulário político e conjuntura, op. cit., p. 126.

${ }^{318}$ Por exemplo, Sublevar: v. at. Levantar, elevar debaixo ao alto "deu hum mar que sublevou a não" que estava assentada no baixo. Couto, 10.7. 2. § Fazer que os subditos rebellem, e se levantem contra o seu legitimo Senhor, e Superior, ou Rei. Provas da Ded. Chronol. f. 155. Sublevar-se, rebella. In.: SILVA, Antonio Moraes. Diccionario da lingua portugueza, op. cit., p. 731.

${ }^{319}$ VILAR, Pierre. Pátria y Nación en el vocabulario de la guerra de la independencia espanhola. In.: Hidalgos, amotinados y guerrilleros. Barcelona: Critica, 1982, p. 211-252.

${ }^{320}$ FERNANDEZ SEBASTIÁN, Javier. Revolucionarios y liberales. Conceptos e identidades polítias en el mundo atlántico, op cit., p. 222-225.
} 
visto na francesa", um exemplo muito significativo do interesse de seus protagonistas em distanciar-se do modelo francês. ${ }^{321}$

Estas concepções de revolução vinculadas ao exemplo do que seria totalmente indesejável, estavam disponíveis no universo vocabular deste espaço amplo de discussão política onde estavam inseridos o Correio Brasiliense e o Correo del Orinoco. Então, natural que na América espanhola a compreensão do termo revolução não trilhasse um caminho diferente, apesar de submetida a situações específicas.

Em março de 1815, José Domingos Díaz, editor da Gaceta de Caracas, veiculou a seguinte reflexão:

"Pues que la ignorancia, la malignidad, o la equivocación hacen constantemente en las revoluciones desfigurar los sucesos, abultar, o disminuir los hechos, y aun suponer los que no han existido para dar lugar a la venganza, y a todos los tiros del resentimiento y del interés personal; (...)".322

A confiarmos na perspicácia das palavras da Gaceta os impulsores ou simpatizantes dos movimentos revolucionários, como o da Venezuela, necessitariam justificar suas atitudes como último recurso contra a "exploração de monopólio criminoso", a "tiraria" e "despotismo". ${ }^{323}$ O argumento de que a América foi “compelida violentamente, por sua própria metrópole a separar-se para sempre dela”, era recorrente nos discursos defensores da causa independentista. Nesse tipo de justificativa para o empreendimento de transformações cuja radicalidade era, de diversos modos e em diferentes níveis, percebida por seus propositores, a defesa de

321 Citado por FÉRNANDEZ SEBASTIÁN, Javier. Revolucionarios y liberales. Conceptos e identidades polítias en el mundo atlántico, op cit., p. 224-225.

${ }^{322}$ Gaceta de Caracas, n. ${ }^{\circ}$ 7, 15 de março de 1815, op. cit., vol. 4, p. 51 (grifo meu).

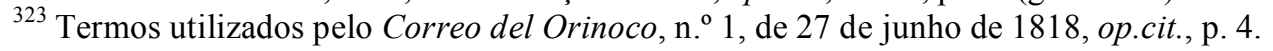


ideais como a soberania dos povos e sua respectiva liberdade - esta pensada como direito natural - é evocada de modo reiterado por alguns de seus agentes. É precisamente este o caso do Correo del Orinoco quando refutou o texto de Hipólito da Costa sobre o movimento de 1817 em Pernambuco. ${ }^{324}$

Contudo, nos espaços públicos de discussão, compartilhados entre as Américas espanhola e portuguesa, pode-se dizer que, nas duas primeiras década do século XIX, o termo revolução é evitado. Inclusive nos discursos do movimento republicano na Venezuela. A “Ata de Declaração da Independência da Venezuela” de 1811, por exemplo, não mencionara o vocábulo. O que não seria estranho num documento - apesar de firmado à revelia da maioria da população -, ${ }^{325}$ que exaltava valores de igualdade e liberdade ao declarar as "Províncias Unidas de Venezuela, estados livres, soberanos e independentes". ${ }^{326}$ Ou seja, os mesmos valores inspiradores da dita Revolução francesa, ao menos no plano discursivo. Apesar da inspiração, os protagonistas do processo na Venezuela se autodenominam "patriotas" ao invés de revolucionários. Os "horrores" dos desdobramentos do processo na França ainda estavam muito vivos na memória da opinião pública - frequentemente lembrados por impressos em todo o mundo ocidental no período -, por isso o uso do termo exigia cuidados para não vincular o movimento venezuelano pró-independência aos exageros do processo francês. Pelo mesmo motivo, a própria identidade política republicana era camuflada oficialmente. Conforme esclarecido por Thibaud, a luta na Venezuela foi convertida, na teoria, em um combate de emancipação patriótica, evitando caracterizar o inimigo por sua identidade política. "Em 1813, Simón Bolívar evita cuidadosamente a palavra revolução em Nova Granada, enquanto a utiliza

\footnotetext{
${ }^{324}$ Ver páginas 128 a 132

325 QUINTERO, Inês. Un salto en el abismo, op. cit.; THIBAUD, Clément. Repúblicas en armas, op. cit., p. 91-97.

${ }^{326}$ Acta de la Independencia de Venezuela. In.: Gazeta de Caracas, 16 de julho de 1811, op. cit.
} 
plenamente depois de ter conquistado o poder em Caracas. Esta precaução se deve sem dúvida ao caráter demasiado radical e revolucionário da ideia republicana. A ideologia da ruptura - independentista ou revolucionária - não havia amadurecido ainda no espírito da cultura política da época". ${ }^{327}$

Por este motivo, o uso do termo seria evitado, ou usado com muita cautela, durante os anos seguintes - decisivos para o processo que levaria à independência política venezuelana. A publicação de um artigo em resposta às acusações contidas em despachos do general espanhol Pablo Morillo - interceptados pelo movimento republicano -, publicado em julho de 1818, é um exemplo raro do uso do termo nas publicações do Correo del Orinoco, naquele ano:

"Todos los Estados independientes de América tienen sistemas más o menos análogos: Todos son Republicanos, Federales, y Democráticos, los más opuestos al Gobierno Militar, los más liberales que se conocen, (...). ¿Cómo se puede llamar Gobierno Militar un sistema, en el cual la soberanía está dividida en tres poderes, en que los militares están privados del derecho de sufragio: en el cual la Igualdad y Libertad son las primeras bases: Bases que de día en día se van fortificando mas y mas, y que no se han desmentido por un solo momento en todo el curso de nuestra revolución?". 328

$\mathrm{Na}$ defesa da causa que seria, gradativamente e cada vez mais, caracterizada por revolucionária, além da evocação dos supostamente elevados ideais de liberdade e igualdade, os Estados em formação foram descritos como "os mais liberais que se

\footnotetext{
327 THIBAUD, Clément. Repúblicas en armas, op. cit., p. 96-97.

328 "Observaciones sobre los despachos de Morillo a su corte relativos al estado de Venezuela". In.: Correo del Orinoco, n. ${ }^{\circ}$ 4, 18 de julho de 1818, op. cit., p. 15 (grifo meu).
} 
conhecem". O uso do termo "liberal" parece absolver a revolução de qualquer carga negativa, parecendo quase dicotômicos no universo semântico do período. ${ }^{329}$

Assim, as várias utilizações do vocábulo revolução refletem o caráter multifacetado, instável e imprevisível do cenário político que era experimentado, apreendido e comunicado por seus protagonistas, frequentemente com dificuldade de precisão.

${ }^{329}$ FÉRNANDEZ SEBASTIÁN, Javier. Dos identidades políticas: Revolucionários y Liberales. In.: CALDERÓN, Maria Teresa e THIBAUD, Clément. Las Revoluciones en el mundo atántico, op. cit., p. 241-247. 


\section{CONCLUSÕES}

Podemos, portanto, concluir que o termo revolução, no vocabulário político da época, era indissociável da experiência francesa, ou seja, relacionado tanto ao horror e caos provocados pela violência da guerra, como aos elevados ideais ditos modernos liberdade, igualdade, direito. A adoção de um ou outro conteúdo era determinada por interesses específicos em discurso.

Esta aparente maleabilidade do termo - ou seja, seu caráter não hegemônico - é consequência da concepção de novas noções incorporadas a ele a partir da elaboração - ainda em andamento - de um passado recente, marcado pela experiência inaugurada na França em 1789. Na América ibérica, soma-se a este quadro geral de formatação de um conceito de revolução, a instabilidade e provisoriedade do contexto político, decorrentes de processos acelerados, e por isto, de difícil elaboração na esfera dos discursos. Somente alguns anos depois, o termo revolução será reabilitado total ou parcialmente por sua "historização": em outras palavras, pelo distanciamento intelectual na elaboração do(s) produto(s) de um processo revolucionário, ou seja, a(s) Independência(s). Assim, o processo revolucionário se justificaria então por seus resultados. $^{330}$

Dessa maneira, o debate entre o Correio Braziliense e o Correo de Orinoco o primeiro, defensor da manutenção da ordem monárquica portuguesa, e o segundo,

\footnotetext{
${ }^{330}$ FÉRNANDEZ SEBASTIÁN, Javier, op cit., p. 228-230. Para o caso da independência do Brasil: PIMENTA, João Paulo Garrido. A independência do Brasil como uma revolução: história e atualidade de um tema clássico. In.: Revista digital História da Historiografia, n. ${ }^{0}$ 03, 2009, p. 53-82: http://www.ichs.ufop.br/rhh/index.php/revista/issue/current. O próprio Hipólito da Costa ao fazer uma análise histórica da independência política do Brasil, em outubro de 1822, iniciou o seu discurso afirmando que "O Brasil seguindo o exemplo das outras seções da América, começou em 1817 a desenvolver os desejos de liberdade civil (...).": Correio Braziliense n. ${ }^{\circ}$ 173, outubro de 1822, vol. 29, p. 468 - agradeço a indicação da amiga Cristiane Alves Camacho dos Santos. Para uma análise de como o termo revolução balizaria a problematização de continuidades e descontinuidades na posteior historiografia da independência do Brasil vide: COSTA, Wilma Peres. A independência na historiografia brasileira. In.: JANCSÓ, István (org.), Independência: História e Historiografia, op. cit., p. 53-118.
} 
porta-voz da projetada República da Venezuela -, evidencia a defesa de diferentes posicionamentos e projetos políticos existentes nas Américas portuguesa e espanhola, respectivamente. Projetos estes que entendiam o termo revolução no seu sentido moderno, ou seja, como meio de total ruptura com determinada ordem estabelecida. Dessa maneira, revolução deveria ser evitada na América portuguesa monarquista por acarretar fragmentação e quebra de princípios a serem, a todo custo, sustentados; e na projetada República da Venezuela, deveria unir forças, em torno dessa mesma concepção do termo, como meio de promoção da tão desejada independência em relação à antiga metrópole.

Pelo menos, era nisso que acreditavam, respectivamente, o Correio Brasiliense e o Correo del Orinoco. A realidade em que eles se inseriam, na qual e pela qual debateram entre os anos de 1817-1820, mostrar-se-ia, contudo, refratária à concretização de projetos bem delineados, de modo que, dos processos de independência ibero-americanos, surgiriam um Brasil e uma Venezuela permeados de conflitos e contradições. 


\section{FONTES}

ACTA de la Assembleia Constituinte da Junta Suprema de Governo de Caracas. Biblioteca Virtual Miguel de Cervantes. In.:

http://www.cervantesvirtual.com/servlet/SirveObras/04700741222647284199079/ind ex.htm

ACTA de la Independencia de Venezuela. Gazeta de Caracas, Venezuela, 16 de julho de 1811. In.: Gaceta de Caracas. Edicion Facsimilar. Caracas: Academia Nacional de La Historia, 1984, volume 3

CARTAS del Libertador. Caracas: Fundacion Vicente Lecuna, 1964, 8 volumes

COSTA, Hipólito José da. Correio Braziliense ou Armazén Literário, 1808-1822. São Paulo: Imprensa Oficial do Estado, 2002, 30 volumes

DOCUMENTOS relativos à Revolução de Pernambuco em 1817. In.: Documentos Históricos. Biblioteca Nacional, Divisão de Obras Raras, volumes 101 ao 109.

GACETA de Caracas (1815-1821). Edição fac-similar em comemoração ao Bicentenário de Simón Bolívar. Caracas: Biblioteca de la Academia Nacional de la Historia, 1983, volumes 4 ao 7.

JULGAMENTO do General Manuel Piar. Cuartel General de Angostura, 15 de outubro de 1817. In.:

http://www.simon-bolivar.org/principal/bolivar/juicio_a_piar.html

RIVAS MORENO, Geraldo (ed.). Correo del Orinoco - Angostura (Venezuela) 1818-1821. Edicion Facsimilar. Bogotá: Fundación FICA, 1998.

\section{DICIONÁRIOS e OBRAS DE REFERÊNCIA}

DICCIONARIO Multimedia de Historia de Venezuela. Fundación Polar: Caracas.

FRANCISCO FUENTES, Juan; FERNÁNDEZ SEBASTIÁN, Javier. Revolución. In.: Diccionario político y social del siglo XIX espanhol. Madri: Alianza Editorial, 2002, p. 628-638.

MORAES SILVA, Antonio. Diccionario da lingua portugueza recopilado dos vocabularios impressos até agora, e nesta segunda edição novamente emendado, e muito accrescentado, por Antonio de Moraes Silva natural do Rio de Janeiro. Offerecido ao muito alto, e muito poderoso Principe Regente N. Senhor. Lisboa: Typographia Lacerdina, 1813. 


\section{BIBLIOGRAFIA}

ALEXANDRE, Valentim. Os sentidos do império. Questão Nacional e questão colonial na crise do Antigo Regime português. São Paulo: Edições Afrontamento, 1993.

ANDERSON, Benedict. Nação e consciência nacional. São Paulo: Ática, 1989.

ANGELES SERRANO, María de los; VENEGAS, Asalia. El Correo del Orinoco: un Instrumento poderoso en la Independencia de América Latina. In.: Bolivar y el periodismo. Seminário latino-americano. Caracas. Publicaciones del Congreso de la Republica de Venezuela, 1983, p. 251-286.

ARAÚJO, Ana Cristina. Um império, um reino e uma monarquia na América: as vésperas da Independência do Brasil. In.: JANCSÓ, István (org.). Independência: história e historiografia. São Paulo: Hucitec, 2005.

ARENDT, Hannah. Sobre revolução. Lisboa: Relógio d'Água Editores, 2001.

ARTOLA, Miguel. La burguesía Revolucionaria (1808-1874). 5. ed. Madri: Alianza Editorial, 1977.

BERBEL, Márcia Regina. Pátria e patriotas em Pernambuco: nação, identidade e vocabulário político (1817-1822). In.: JANCSÓ, István (org.). Brasil: formação do estado e da nação. São Paulo: Hucitec/Fapesp/Ed. Unijuí, 2003.

BERNARDES, Denis Antônio de Mendonça. $O$ Patriotismo constitucional: Pernambuco, 1820-1822. São Paulo: Hucitec/FAPESP; Recife: Editora Universitária UFPE, 2006.

CABRAL. Flavio José Gomes. A república de Pernambuco. Revista de História da Biblioteca Nacional, Rio de Janeiro, n. ${ }^{\circ}$ 30, mar. 2008.

CALDERÓN, Maria Teresa; THIBAUD, Clément (org.). Las Revoluciones en el mundo atlántico. Bogotá: Universidad Externado de Colômbia/Tauros Historia, 2006.

CASTRO, Leiva. De la patria boba a la teologia bolivariana. Caracas: Fundación Polar/Universidad Católica Andrés Bello, 2005, volume 1.

CORREA, Luis; DUARTE LEVEL, Lino. La doctrina de la revolución emancipadora en el Correo del Orinoco. Caracas: Academia Nacional de História, s.d.

COSTA, Fernando Hypólito da. Notas genealógicas: o ramo brasileiro. In.: COSTA, Hipólito José da. Correio Braziliense ou Armazém Literário. São Paulo: Imprensa Oficial do Estado, 2002, p. 269-321, volume 30, tomo 1. 
COSTELLA, Antônio F. Notas genealógicas: o ramo inglês. In.: COSTA, Hipólito José da. Correio Braziliense ou Armazém Literário. São Paulo: Imprensa Oficial do Estado, 2002, p. 161-167, volume 30, tomo 1.

DIAS, Maria Odila da Silva. A interiorização da Metrópole. 1808-1853. In.: MOTA, Carlos Guilherme (org.). 1822: Dimensões. São Paulo: Perspectiva, 1972.

DINES, Alberto. O patrono e seu modelo. In.: COSTA, Hipólito José da. Correio Braziliense ou Armazém Literário. São Paulo: Imprensa Oficial do Estado, 2002, volume 1 .

DOURADO, Mecenas. Hipólito da Costa e o Correio Braziliense. Rio de Janeiro: Biblioteca do Exército Editora, 1957, 2 volumes.

FEBRES CORDERO, Julio. Historia de la imprenta y del periodismo en Venezuela (1800-1830). Caracas: Banco Central de Venezuela, 1974.

FÉRNANDEZ SEBASTIÁN, Javier. Revolucionarios y liberales. Conceptos e identidades politicas en el mundo atlántico. In.: CALDERÓN, Maria Teresa; THIBAUD, Clément (org.). Las Revoluciones en el mundo atlántico. Bogotá: Universidad Externado de Colômbia/Tauros Historia, 2006, p. 215-250.

FERREIRA REIS, Arthur Cezar. Neutralidade e boa vizinhança no início das relações entre brasileiros e venezuelanos - documentário. Revista do Instituto Histórico e Geográfico Brasileiro, Rio de Janeiro, volume 235, abr./jun. 1957.

FONTANA, Josep. La crisis del antiguo régimen (1808-1833). 4. ed. Barcelona: Grijalbo, 1992.

GODECHOT, Jacques. Independência do Brasil e a revolução do ocidente. In.: MOTA, Carlos G. (org.). 1822: Dimensões. São Paulo: Perspectiva, 1972, p. 27-37. . As Revoluções (1770-1799). São Paulo: Pioneira, 1976.

GÓMEZ, Alejandro E. The 'Pardo Question'. Revista digital Nuevo Mundo Mundos Nuevos, Materiales de seminarios, 15 set. 2008. In.:

http://nuevomundo.revues.org/index34503.html

. Del affaire de los mulatos al asunto de los pardos. In.: CALDERÓN, Maria Teresa; THIMBAUD, Clément (org.). Las Revoluciones en el mundo atántico. Bogotá: Universidad Externado de Colômbia/Tauros Historia, 2006, p. 301-321.

La revolución haitiana y la tierra firme hispana. Revista digital Nuevo Mundo Mundos Nuevos, Debates 2005, 17 fev. 2006. In.:

$\mathrm{http}: / /$ nuevomundo.revues.org/index211.html

GRASES, Pedro. El primer taller: Gallagber y Lamb, 1808. In.: História de la imprenta en Venezuela. Hasta el fin de la Primera Republica (1812). Caracas: Ediciones de la Presidência e la Republica, 1967. 
editoriales de Caracas. Caracas: Ed. de El Nacional, 1958.

. (comp.). Orígenes de la imprenta en Venezuela y primicias

GUERRA, François-Xavier. Modernidad e independencias. Ensayos sobre las revoluciones hispânica. México: Ed. Mafre/Fondo de Cultura Económica, 1993.

; LEMPÉRIÈRE, Annick. Los espacios públicos em Iberoamérica.

México: Fondo de Cultura Económica, 1998.

HABERMAS, Jurgen. Historia y critica de la opinión pública. México: Ediciones G. Gili, 1986.

HALPERIN DONGHI, Tulio. Reforma y disolución de los impérios ibéricos. 17501850. Madrid: Alianza Ed., 1985.

HEBRARD, Véronique. Une nation par le discours: le Venezuela (1808-1830). Paris: l'Harmattan, 1997.

HOBSBAWM, Eric J. A era das revoluções. 10. ed. São Paulo: Paz e Terra, 1997.

HOLANDA, Sérgio Buarque (dir.). História geral da civilização brasileira. São Paulo: Difusão Europeia do Livro, 1970, volume1, tomo 2.

IZARD, Miguel. El miedo a la revolucion. La lucha por la libertad en Venezuela (1777-1830). Madri: Editorial Tecnos, 1979.

JANCSÓ, István (org.), Independência: História e Historiografia. São Paulo: Hucitec - Fapesp, 2005.

; SLEMIAN, Andréa. Um caso do patriotismo imperial. In.: COSTA, Hipólito José da. Correio Braziliense ou Armazém Literário. São Paulo: Imprensa Oficial do Estado, 2002, volume 30, tomo1.

; PIMENTA, João Paulo Garrido. Peças de um mosaico (ou apontamentos para o estudo da emergência da identidade nacional brasileira. In.: MOTA, Carlos Guilherme (org.). Viagem Incompleta. A experiência brasileira 15002000. São Paulo: SENAC, 2000.

KOSELLECK, Reinhart. Crítica e Crise: uma contribuição à patogênese do mundo burguês. Rio de Janeiro: Ed. UERJ/Contraponto, 1999.

. Futuro passado. Contribuição à semântica dos tempos históricos. Rio de Janeiro: Contraponto/Editora PUC-Rio, 2006.

LIMA, Oliveira. Dom João VI no Brasil. 1808-1821. 3. ed. Rio de Janeiro: Topbooks, 1996.

LEITE, Glacyra Lazzari. Pernambuco (1817). Recife: Fundação Joaquim Nabuco/Editora Massangana, 1988. 
LYNCH, John. Las revoluciones hispanoamericanas (1808-1826). 8. ed. Barcelona: Ariel, 2001.

LUSTOSA, Isabel. His Royal Highness e Mr. Da Costa. In.: COSTA, Hipólito José da. Correio Braziliense ou Armazém Literário. São Paulo: Imprensa Oficial do Estado, 2002, p. 15-61, volume 30, tomo 1.

MARQUESE, Rafael de Bivar. Administração e escravidão. São Paulo: Hucitec, 1999.

MARTINS, Ana Luiza; LUCA, Tania Regina de (org). História da imprensa no Brasil. São Paulo: Contexto, 2008.

MELLO, Evaldo Cabral de. A outra independência. O federalismo pernambucano de 1817 a 1824. São Paulo: Editora 34, 2004.

MIJARES, Augusto. El Libertador. Caracas: Academia Nacional de la Historia/Ediciones de la Presidencia de la República, 1987.

MOREL, Marco. Independência no papel: a imprensa periódica. In.: JANCSÓ, István (org.). Independência: história e historiografia. São Paulo: Hucitec/Fapesp, 2005, p. 617-636.

; BARROS, Mariana Monteiro. Palavra, imagem e poder. $O$ surgimento da imprensa no Brasil do século XIX. Rio de Janeiro: DP\&Editora, 2003.

- La gênesis de la opinión pública moderna y el proceso de independencia. Rio de Janeiro (1820-1840). In.: GUERRA, François-Xavier; LEMPÉRIÈRE, Annick. Los espacios públicos em Iberoamerica: ambiguedades y problemas. Siglos XVIII-XIX. México: F.C.E., 1998.

MOTA, Carlos Guilherme (org.). Viagem incompleta. A experiência brasileira (15002000). São Paulo: SENAC, 2000.

. 1822: dimensões. São Paulo: Perspectiva, 1986.

1982. . Nordeste 1817: estruturas e argumentos. São Paulo: Perspectiva,

NEVES, Lúcia Maria Bastos P. Revolução em busca do conceito no império lusobrasileiro (1799-1822). In.: FERES Júnior, João; JASMÍN, Marcelo (org.). História dos conceitos. Diálogos transatlânticos. Rio de Janeiro: Editora PUC Rio/Loyola/IUPERJ, 2007.

NOVAIS, Fernando. Portugal e o Brasil na crise do Antigo Sistema Colonial (17771808). São Paulo: Hucitec, 1979. 
PACHECO TROCONIS, Germán. La sociedad económica de Amigos del País de Caracas, el conocimiento agronómico y el progreso agrícola (1830-1844). Revista Tierra Firme, volume 21, n. 83, p. 335-350, jul. 2003. In.:

http://www2.scielo.org.ve/scielo.php?script=sci_arttext\&pid=S0798-

29682003000300006\&lng=es\&nrm=iso >. ISSN 0798-2968

PÁEZ, José Antonio. Autobiografia. Nova York: H. R. Elliot, 1945 (1867).

PARRA-PEREZ, Caracciolo. Historia de la primera republica de Venezuela. Caracas: Biblioteca Nacional de História, 1959, 2 volumes.

PAULA, Sérgio Goes de; LIMA, Patrícia Souza. Os paradoxos da liberdade. In.: COSTA, Hipólito José da. Correio Braziliense ou Armazém Literário. São Paulo: Imprensa Oficial do Estado, 2002, p. 111-161, volume 30, tomo 1.

PEREIRA, Sara Marques. D. Carlota Joaquina e os "espelhos de Clio": actuação política e figurações historiográficas. Lisboa: Horizonte, 1999.

PÉREZ VILA, Manuel. Bolívar y el Periodismo. In.: Bolívar y el periodismo. SEMINÁRIO LATINO-AMERICANO, 1983, Caracas. Publicaciones del Congreso de la Republica de Venezuela, 1983, p. 287-296.

PIMENTA, João Paulo Garrido. A independência do Brasil como uma revolução: história e atualidade de um tema clássico. Revista História da Historiografia, n. 03, 2009, p. 53-82. In.:

http://www.ichs.ufop.br/rhh/index.php/revista/issue/current

O Brasil e a América Espanhola (1808-1822). São Paulo, 2003.

Tese de doutorado - Faculdade de Filosofia, Letras e Ciências Humanas/USP.

. A política hispano-americana e o império português (1810-1817).

Vocabulário político e conjuntura. In.: JANCSÓ, István (org.). Brasil: formação do estado e da nação. São Paulo: Hucitec/Fapesp/Ed. Unijuí, 2003.

. Estado e nação no fim dos Impérios ibéricos no Prata (18081828). São Paulo: Hucitec, 2002.

PINO ITURRIETA, Elias A. La mentalidade venezolana de la emancipacion (18101812). Caracas: Universidad Central de Venezuela, 1971.

. Mantuanos e Independencia. In.: Gran enciclopédia de

Venezuela. Caracas: Editorial Globe, 1998, tomo 3, p. 251 et seq.

POCOCK, J. G. A. Linguagens do ideário político. São Paulo: Edusp, 2003.

PRADO JR., Caio. Evolução política do Brasil: colônia e império. 20. ed. São Paulo: Brasiliense, 1989. 
QUINTERO, Inés. Soberania, representación e independencia en Caracas (18081811). In.: Procesos. Revista Ecuatoriana de Historia, Quito, n. 29, p. 5-20, $1^{\circ}$ sem. 2009.

. Los nobles de Caracas. Caracas, Academia Nacional de História, 2005. In.: www.anhistoriavenezuela.org/pdf/discursos/dis34.pdf

Andrés Bello, 2002.

La conjura de los mantuanos. Caracas: Universidad Católica

. Un salto en el abismo. Caracas, Biblioteca electrónica, jul. 2000.

In.: http://www.analitica.com/bitBlioteca/venezuela/5julio.asp

RIZZINI, Carlos. Hipólito da Costa e o Correio Braziliense. São Paulo: Companhia Editora Nacional, 1957.

RODRÍGUEZ, Jaime E. La independencia de la América española. México: Fondo de Cultura Econômica, 2006.

RODRÍGUEZ, Manuel Alfredo. El Correo del Orinoco, periódico de la emancipación americana. Caracas: Instituto Nacional de cultura y Bellas Artes, s.d.

ROSAS MARCANO, Jesús; SANOJA HERNÁNDEZ, Jesús; FRANCISCO LIZARDO, Pedro. Papel de la prensa en la lucha por la independência de Venezuela. In.: Bolivar y el periodismo. SEMINÁRIO LATINO-AMERICANO, 1983, Caracas. Publicaciones del Congreso de la Republica de Venezuela, 1983, p. 237-245.

SALCEDO-BASTARDO, José Luis. Historia fundamental de Venezuela. 11. ed. Caracas: Universidad Central de Venezuela/Ediciones de la Biblioteca, 2006.

SEGUNDO SÁNCHEZ, Manuel. La imprenta de la Expedición Pacificadora, 1916. In.: Gaceta de Caracas.Edição fac-similar em comemoração ao Bicentenário de Simón Bolívar. Caracas: Biblioteca de la Academia Nacional de la Historia, 1983, volume 7.

SILVA, Luiz Geraldo. Pernambucanos, sois portugueses!. Almanack Braziliense, n. 1, maio 2005. In.: http://www.almanack.usp.br

SILVA, Maria Beatriz Nizza da. A Gazeta do Rio de Janeiro (1808-1822) - cultura e sociedade. Rio de Janeiro: Ed. UERJ, 2007.

SILVA, Renán. Prácticas de lectura, ámbitos privados y formación de un espacio público moderno. In.: GUERRA, François-Xavier; LEMPÉRIÈRE, Annick. Los espacios públicos em Iberoamérica. México: Fondo de Cultura Económica, 1998.

SCHWARCZ, Lilia Moritz. A longa viagem da biblioteca dos reis. Do terremoto de Lisboa à independência do Brasil. São Paulo: Cia das Letras, 2002.

SLEMIAN, Andréa. Vida política em tempo de crise: Rio de Janeiro (1808-1824). São Paulo: Hucitec, 2006. 
; PIMENTA, João Paulo. O nascimento politico do Brasil. As origens do Estado e da Nação (1808-1825). São Paulo: DPA\&A Editora, 2003.

SOARES, Ana Carolina Eiras Coelho; DUARTE, Elaine Cristina Ferreira. O Arquivo Nacional e a História Luso-Brasileira: Caiena. In.:

http://www.historiacolonial.arquivonacional.gov.br/cgi/cgilua.exe/sys/start.htm?infoi $\mathrm{d}=307 \&$ sid $=47 \&$ tpl $=$ printerview

SODRÉ, Nelson Werneck. História da imprensa no Brasil. 4. ed. Rio de Janeiro: Mauad, 1999.

THIBAUD, Clément. De la ficción al mito: los llaneros de la Independencia de Venezuela. In.: CARRERA DAMAS, Germán (org). Mitos políticos en las sociedades andinas: orígenes, invenciones y ficciones. Paris, Caracas, Lima: IFEA, 2006.

Repúblicas en armas. Los ejércitos bolivarianos en guerra de independência en Colômbia e Venezuela. Bogotá: Editorial Planeta, 2003.

TOMÉ, Frederico Castilho. A causa americana na perspectiva do Correio Braziliense $e$ do Correo del Orinoco. Brasília, 2005. Dissertação de mestrado/Universidade de Brasília.

TOUR, Antonio Octavio. Biografía del general Manuel Carlos Piar. Caracas: Venevasco, 1985.

VILAR, Pierre. Pátria y Nación en el vocabulário de la guerra de la independencia espanhola. In.: Idem. Hidalgos, amotinados y guerrilleros. Barcelona: Critica, 1982.

WASSERMAN, Fabio. Revolución. In.: GOLDMAN, Noemi (ed.). Lenguaje y revolución: conceptos politicos clave en el Rio de la Plata, 1780-1850. Buenos Aires: Prometeo Libros, 2008, p. 159-174.

ZERMEÑO PADILLA, Guillermo. La cultura moderna de la historia: una aproximación teórica e historiográfica. México: El Colegio de México, Centro de Estudios Históricos, 2002. 


\section{ANEXOS}

\section{Anexo 1}

Mapa da América do Sul - Século XIX

Fonte: Projeto Mapas Históricos

In.: http://www.rootsweb.ancestry.com/ brawgw/mapashistoricos.htm

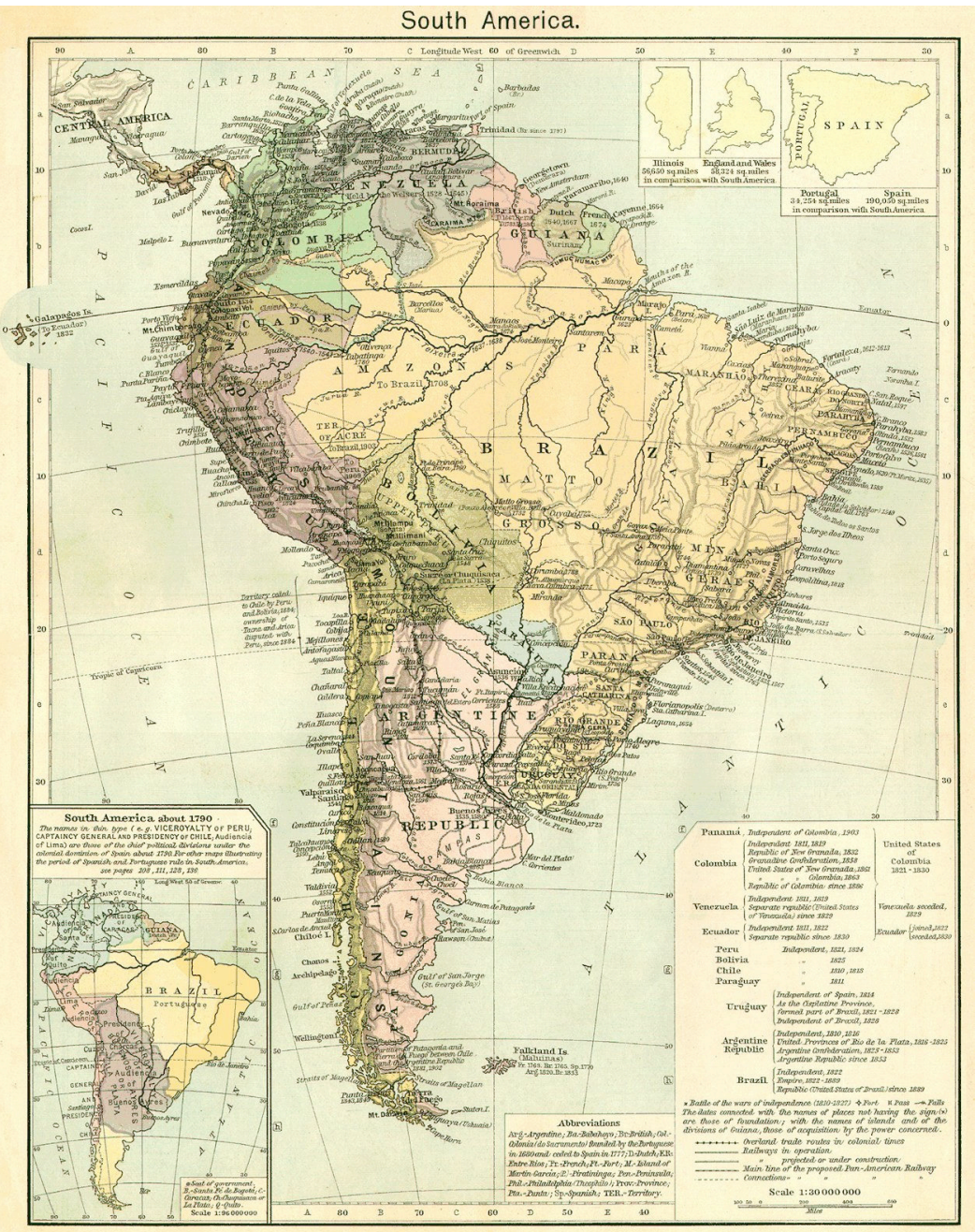


Anexo 2

Mapa da Confederação da Venezuela - Século XIX

Fonte: Caracciolo PARRA-PEREZ. Historia de la primera Republica de Venezuela. Caracas: Biblioteca Nacional de História, 1959

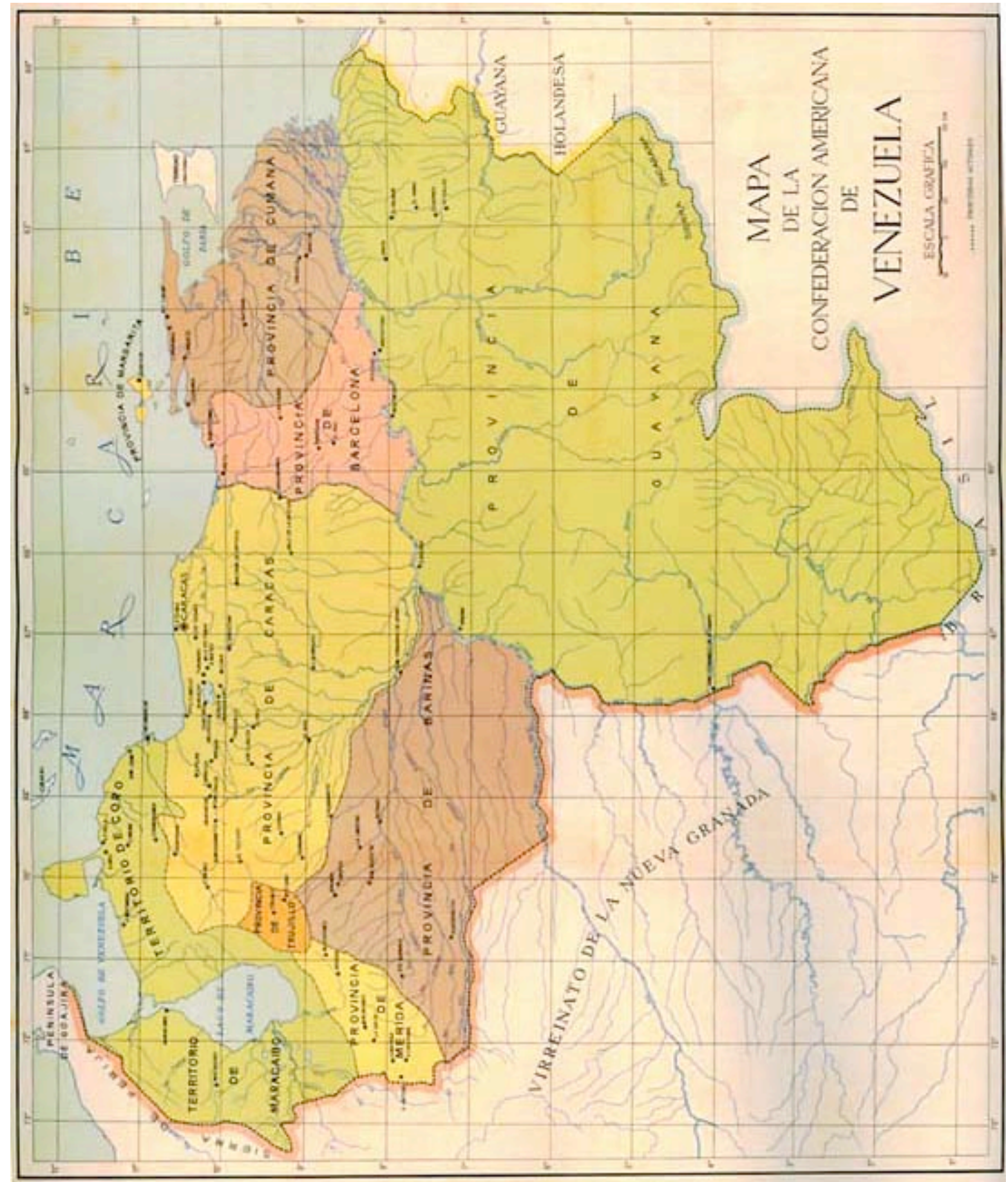




\section{Anexo 3}

Mapa da Fronteira Brasil - Venezuela (configurações atuais)

Fontes: www.infoescola.com/.../08/full-20-532663bbb7.jpg http://www.a-venezuela.com/mapas/map/html/estados/amazonas.html maps.google.com.br

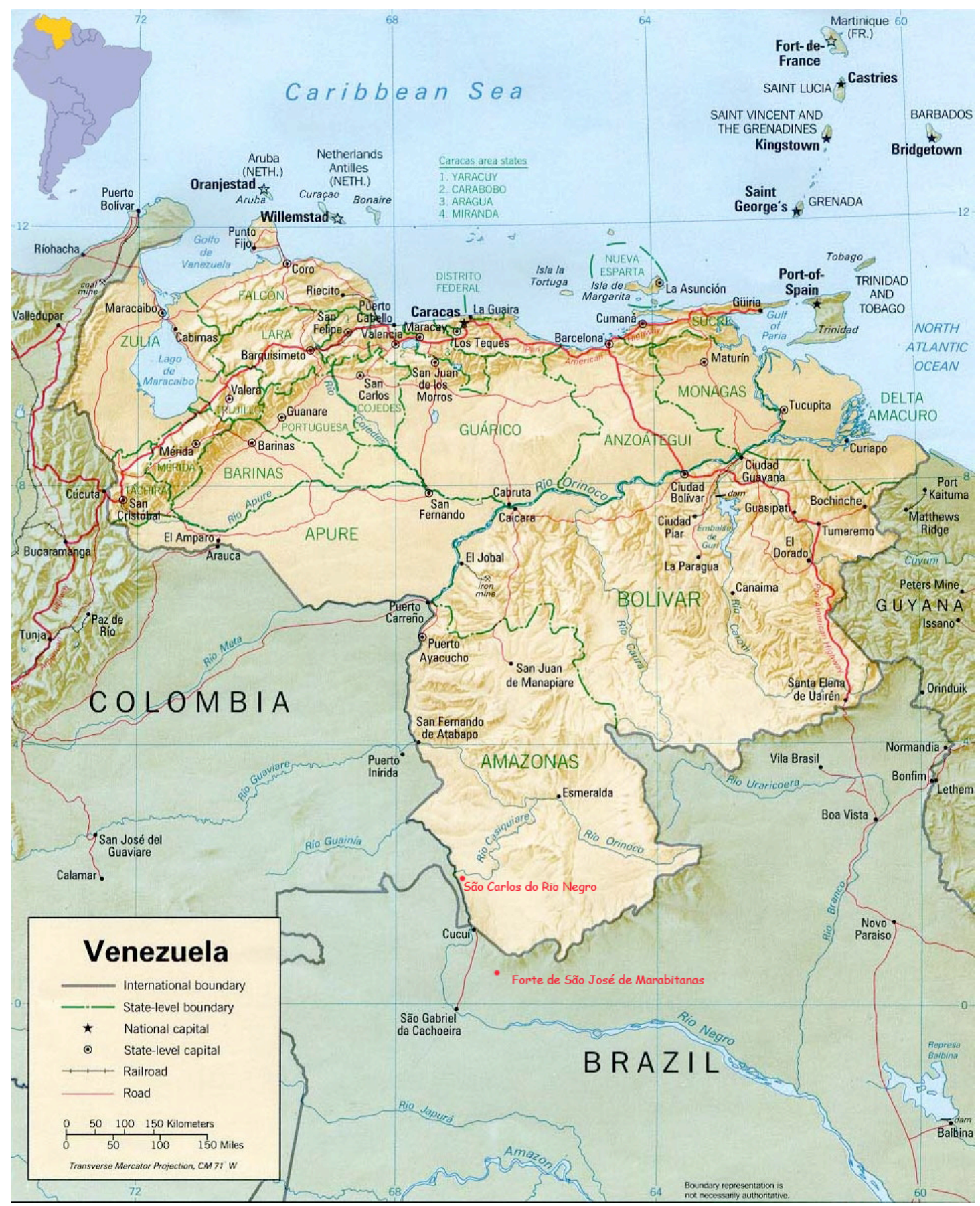

